

\title{
Geochemistry of Mine Waste and Mill Tailings, Meadow Deposits, and Stream Bed Sediment and the General Hydrology and Water Quality of the Frohner Meadows Area, Upper Lump Gulch, Jefferson County, Montana
}



Scientific Investigations Report 2005-5265 


\section{Geochemistry of Mine Waste and Mill Tailings, Meadow Deposits, and Stream Bed Sediment and the General Hydrology and Water Quality of the Frohner Meadows Area, Upper Lump Gulch, Jefferson County, Montana}

By Terry L. Klein, Michael R. Cannon, and David L. Fey

Prepared in cooperation with the U.S. Department of Agriculture Forest Service

Scientific Investigations Report 2005-5265 


\section{U.S. Department of the Interior \\ Gale A. Norton, Secretary \\ U.S. Geological Survey \\ P. Patrick Leahy, Acting Director}

\section{U.S. Geological Survey, Reston, Virginia: 2006}

Posted online March 2006

Version 1.0

This publication is available only online at http://www.usgs.gov/sir/2005/5265

For more information on the USGS - the Federal source for science about the Earth, its natural and living resources, natural hazards, and the environment:

World Wide Web: http://www.usgs.gov

Telephone: 1-888-ASK-USGS

Any use of trade, product, or firm names is for descriptive purposes only and does not imply endorsement by the U.S. Government.

Although this report is in the public domain, permission must be secured from the individual copyright owners to reproduce any copyrighted materials contained within this report.

Suggested citation:

Klein, T.L., Cannon, M.R., and Fey, D.L., 2006, Geochemistry of mine waste and mill tailings, meadow deposits, and stream bed sediment and the general hydrology and water quality of the Frohner Meadows area, upper Lump Gulch, Jefferson County, Montana: U.S. Geological Survey Scientific Investigations Report 2005-5265, 50 p. 


\section{Contents}

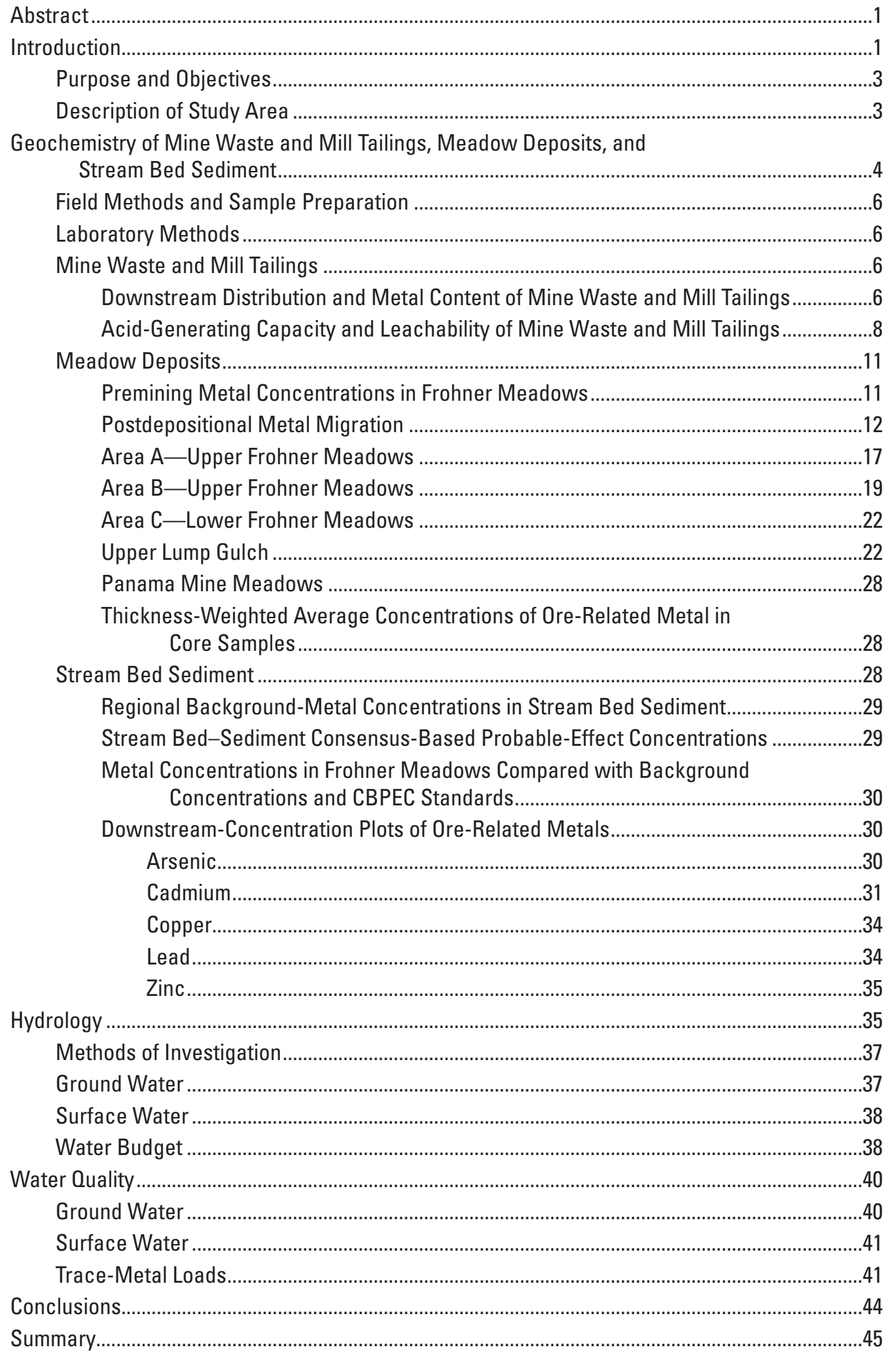


Mine Waste and Mill Tailings ............................................................................................... 45

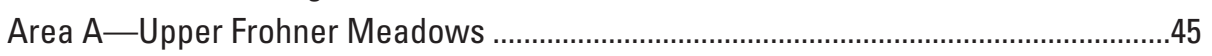

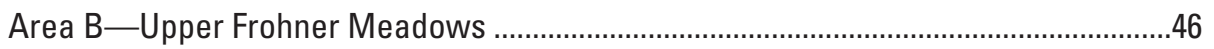

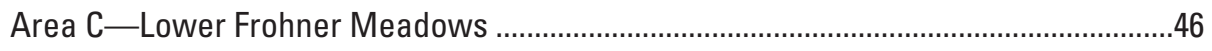

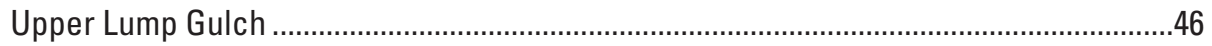

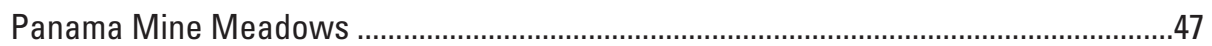



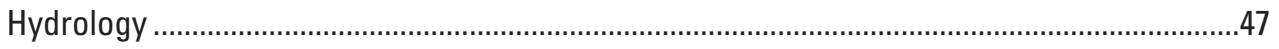

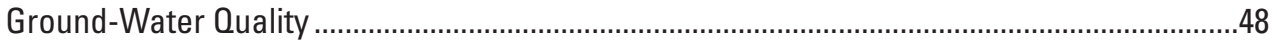

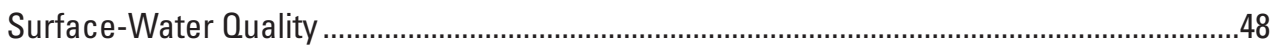

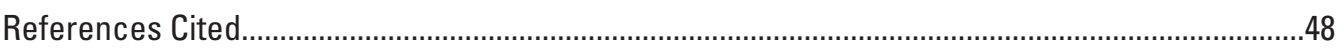

\section{Figures}

1-3. Maps showing location of:

1. Frohner Meadows study area within upper Prickly Pear Creek watershed, Montana

2. Frohner Meadows study area and geographic features............................................

3. Stream bed-sediment, individual core, and composite mill-tailings sample sites and core lines in Frohner Meadows and upper Lump Gulch.

4. Ternary plot of total concentrations of arsenic, lead, and zinc in mine waste, unprocessed ore, and mill tailings from Frohner Meadows area

5. Diagram showing acid-generating capacity and yields of ore-related metal in mine waste and mill tailings from Frohner Meadows area and two other mine sites..............10

6. Composite image and geochemical profile of core 1-150 ..............................................13

7. Composite image and geochemical profile of core 3-250 ..............................................14

8. Map of upper mill tailings area (area A) showing thickness of metal-enriched material and depth to bottom of enriched interval

9. Map of main mill tailings area (area B) showing thickness of enriched material and depth to bottom of enriched interval.

10. Photograph of trench showing cross section of mill-tailings debris fan along Frohner Meadows creek.

11. Map of upper mill tailings area (area A) showing thickness of enriched material and thickness-weighted averages of metal concentrations in enriched interval.......

12. Photograph of mill tailings exposed along Frohner Meadows creek in main mill-tailings impoundment (area B).

13-16. Maps of:

13. Main mill-tailings area (area B) showing thickness of enriched material and thickness-weighted averages of metal concentrations

14. Frohner Meadows showing location of sampling sites.

15. Lower Frohner Meadows (area C) showing thickness of enriched material and depth to bottom of enriched interval.

16. Lower Frohner Meadows (area C) showing thickness of enriched material and thickness-weighted averages of metal concentrations in enriched interval.

17-22. Downstream-concentration plots of metals in stream bed sediment:

17. Arsenic 


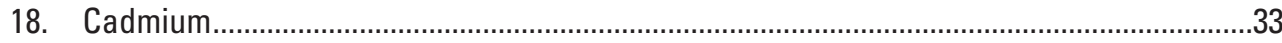

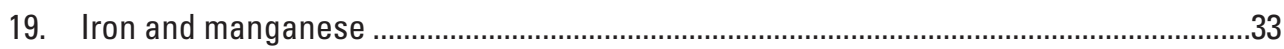

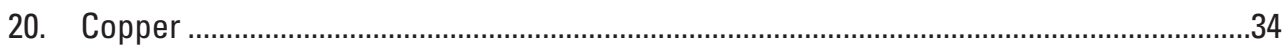

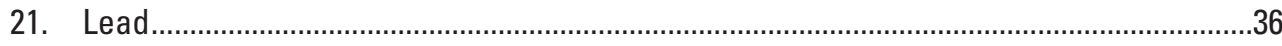

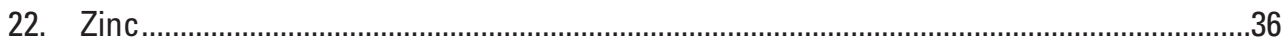

23-27. Histograms showing instantaneous loads of total recoverable metals:

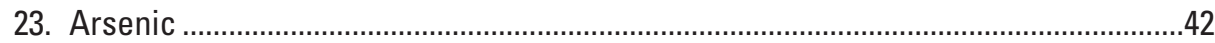

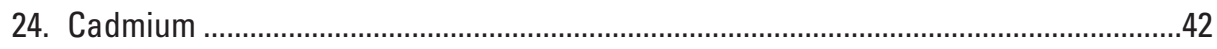

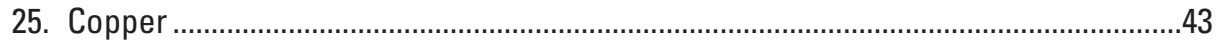

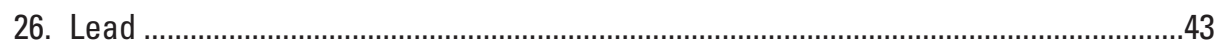

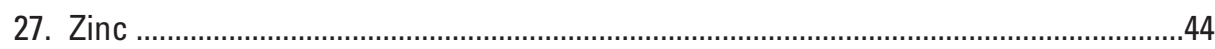

\section{Tables}

1. Net acid-producing capacity of mine waste and mill tailings............................................

2. Means and standard deviations of ore related-metal concentrations in core samples used to define premining conditions in study area ..........................................................12

3. Concentrations and instantaneous loads of total recoverable trace metals in

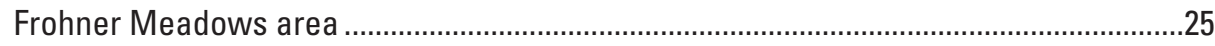

4. Weighted-average concentration of contaminated material in core samples,

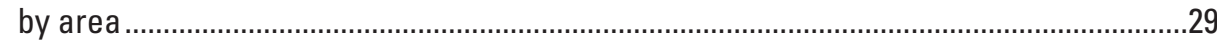

5. Median trace-metal concentrations of regional-background stream bed-sediment samples in upper Prickly Pear Creek watershed and in

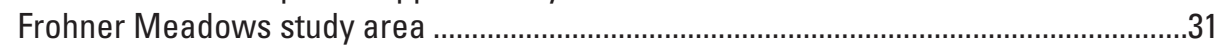

6. Summary of consensus-based probable-effect concentrations of ore-related metals in stream bed sediment .....................................................................

7. Water levels in wells and at surface-water sample sites in Frohner Meadows ..............39

8. Calculated mean monthly discharge and annual discharge of Frohner Meadows creek ..............................................................................................40

9. Summary of annual water budget of Frohner Basin .........................................................

\section{Conversion Factors, Abbreviations, and Symbols}

\begin{tabular}{lcl}
\hline Multiply & By & To obtain \\
\hline cubic foot per second $\left(\mathrm{ft}^{3} / \mathrm{s}\right)$ & 0.028317 & cubic meter per second $\left(\mathrm{m}^{3} / \mathrm{s}\right)$ \\
foot $(\mathrm{ft})$ & 0.3048 & meter $(\mathrm{m})$ \\
inch (in.) & 25.4 & millimeter $(\mathrm{mm})$ \\
mile (mi) & 1.609 & kilometer $(\mathrm{km})$ \\
\hline
\end{tabular}

Temperature can be converted to degrees Celsius $\left({ }^{\circ} \mathrm{C}\right)$ or degrees Fahrenheit $\left({ }^{\circ} \mathrm{F}\right)$ by the following equations:

$$
\begin{aligned}
& { }^{\circ} \mathrm{C}=5 / 9\left({ }^{\circ} \mathrm{F}-32\right) \\
& { }^{\circ} \mathrm{F}=9 / 5{ }^{\circ} \mathrm{C}+32
\end{aligned}
$$




\section{Abbreviated units used in this report:}

$\begin{array}{ll}\mu \mathrm{g} / \mathrm{L} & \text { micrograms per liter } \\ \mu \mathrm{L} & \text { microliter, microliters } \\ \mu \mathrm{m} & \text { micrometer, micrometers (micron, microns) } \\ \mu \mathrm{S} / \mathrm{cm} & \text { microsiemens per centimeter at } 25 \text { degrees Celsius } \\ \text { acre-ft } & \text { acre-foot, acre-feet } \\ \text { acre-ft/yr } & \text { acre-feet per year } \\ \mathrm{in} . & \text { inch, inches } \\ \mathrm{in} . / \mathrm{yr} & \text { inches per year } \\ \mathrm{ft} & \text { foot, feet } \\ \mathrm{ft}{ }^{3} / \mathrm{s} & \text { cubic feet per second } \\ \mathrm{L} & \text { liter, liters } \\ \mathrm{lb} & \text { pound, pounds } \\ \mathrm{m} & \text { meter, meters } \\ \mathrm{meq} / \mathrm{L} & \text { milliequivalents per liter } \\ \mathrm{mg} / \mathrm{L} & \text { milligrams per liter } \\ \mathrm{mm} & \text { millimeter, millimeters } \\ \mathrm{nm} & \text { nanometer, nanometers } \\ \mathrm{oz} & \text { ounce, ounces } \\ \mathrm{ppm} & \text { parts per million } \\ \mathrm{yr} & \text { year, years } \\ \end{array}$

\section{Abbreviations used in this report:}

$\begin{array}{ll}r^{2} & \text { correlation coefficient } \\ \text { CBPEC } & \text { consensus-based probable-effect concentration } \\ \text { EPA } & \text { U.S. Environmental Protection Agency } \\ \mathrm{HCl} & \text { hydrochloric acid } \\ \mathrm{HClO}_{4} & \text { perchloric acid } \\ \mathrm{HF} & \text { hydrofluoric acid } \\ \mathrm{HNO}_{3} & \text { nitric acid } \\ \mathrm{NAP} & \text { net acid production } \\ \text { NGVD } & \text { National Geodetic Vertical Datum } \\ \text { SPLP } & \text { synthetic precipitation leach procedure }\end{array}$




\title{
Geochemistry of Mine Waste and Mill Tailings, Meadow Deposits, and Stream Bed Sediment and the General Hydrology and Water Quality of the Frohner Meadows Area, Upper Lump Gulch, Jefferson County, Montana
}

\author{
By Terry L. Klein, Michael R. Cannon, and David L. Fey
}

\section{Abstract}

Frohner Meadows is an area of subalpine ponds and wetlands in glaciated terrane having a low topographic gradient near the headwaters of Lump Gulch (a tributary of Prickly Pear Creek); it is located about 15 miles west of the town of Clancy, Mont., in the Helena National Forest. During the last 120 years, ore was extracted at two sites (the Frohner mine and the Nellie Grant mine) upstream from Frohner Meadows. Lead-zinc-silver veins in granitic rocks of the Boulder batholith were mined, and the ore was treated nearby. As a result, accumulations of mine waste and mill tailings were distributed downslope and downstream by anthropogenic and by natural processes.

This report presents the results of an investigation of the geochemistry of the wetlands, streams, and unconsolidated sediment deposits and of the hydrology, hydrogeology, and water quality of the area affected by these sources of ore-related metals. Ground-water samples from most shallow wells in the meadows contained high concentrations of arsenic, which exceeded the Montana numeric water-quality standard for human health. Transport of cadmium and zinc in ground water was indicated at one site near Nellie Grant creek (this informal name is applied for convenience to an unnamed tributary) on the basis of water-quality data from one well near the creek. Mill tailings deposited in upper Frohner Meadows contribute large arsenic loads to Frohner Meadows creek (also an informal name); Nellie Grant creek contributes large arsenic, cadmium, and zinc loads to upper Frohner Meadows. Concentrations of total recoverable cadmium, copper, lead, and zinc in most surface-water sites downstream from the Nellie Grant mine exceeded Montana aquatic-life standards. The $\mathrm{pH}$ of nearly all samples of surface water and ground water was neutral to slightly alkaline.

Concentrations of arsenic, cadmium, lead, and zinc in stream bed sediment in the entire meadow below accumulations of mine waste and mill tailings are much higher than background concentrations in the regional watershed, and the meadow concentrations exceed consensus-based, probable-effect concentrations for stream bed sediment at most sites. Cadmium, copper, and zinc typically are adsorbed onto the surface coatings of grains in stream bed sediment. Mine waste and mill tailings contain high concentrations of arsenic, cadmium, copper, lead, and zinc in a quartz-rich matrix. Most of the waste sites that were sampled had low acid-generating capacity, although one site (fine-grained mill tailings from the Nellie Grant mine deposited in the upper part of lower Frohner Meadows) had extremely high acid-generating potential probably because of abundant fine-grained pyrite. Two distinct sites were identified as metal sources on the basis of stream bed-sediment samples, the meadow substrate, and mine and mill-tailings samples. The Frohner mine and mill site contribute material rich in arsenic and lead; similar material from the Nellie Grant mine and mill site is rich in cadmium and zinc.

\section{Introduction}

Frohner Meadows is an area of subalpine ponds and wetlands having a low topographic gradient about 15 miles (mi) west of the town of Clancy, Mont., in the Helena National Forest (fig. 1). Frohner Meadows is located in Frohner Basin, which is in the headwaters of Lump Gulch in the western part of the upper Prickly Pear Creek watershed. Two historical mines, the Frohner and Nellie Grant mines, are located within the Frohner Basin (fig. 2) and upstream from Frohner Meadows. Mill tailings, unprocessed ore, and mine-waste dumps at these mines have been eroded, washed downstream, and deposited in Frohner Meadows on lands administered by the Helena National Forest. A mixture of mill tailings and unprocessed ore in Frohner Meadows covers an area of about 8 acres, mostly in the northern or upstream part of the meadows (Metesh and others, 1998). Parts of the meadow covered by this waste lack vegetation or are covered with dead vegetation.

Previous investigations have shown that water containing high concentrations of dissolved trace metals leaves areas disturbed by mining and enters the ponds and wetlands. Water within Frohner Meadows and runoff from the wetlands 


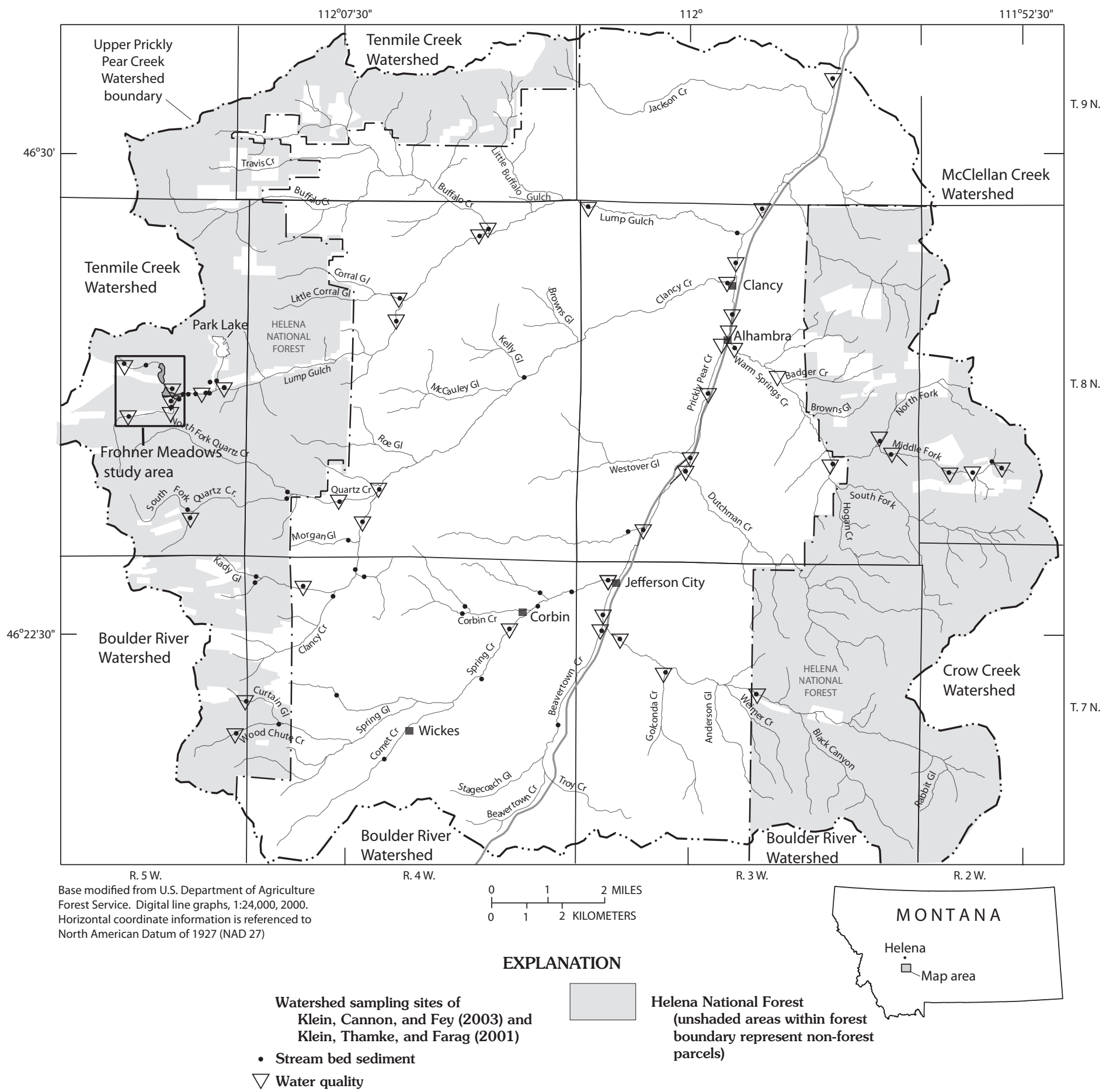

Figure 1. Location of Frohner Meadows study area within upper Prickly Pear Creek watershed, Montana. 


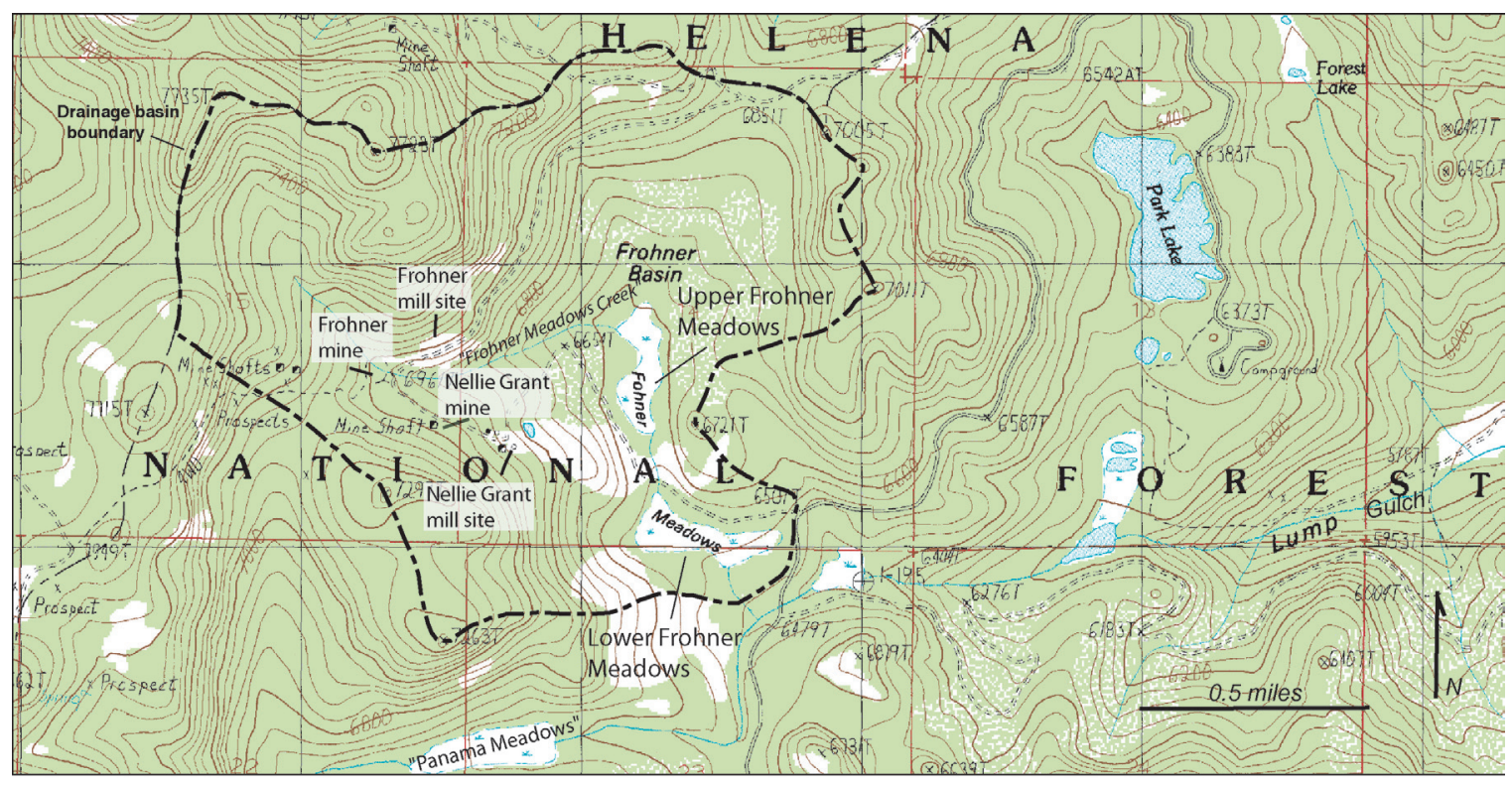

0 0.5 MILES

Figure 2. Location of Frohner Meadows study area and geographic features. Base map from U.S. Geological Survey Chessman Reservoir 71/2 minute topographic quadrangle.

contain concentrations of trace metals that exceed Montana aquatic-life and Montana numeric water-quality standards for human health. Dissolved trace-element concentrations in mine runoff are attenuated by the wetlands; however, water and stream bed sediment downstream from Frohner Meadows contain cadmium and zinc in concentrations that exceed Montana aquatic-life standards for water and consensusbased, probable-effect concentrations (CBPECs) for stream bed sediment (Klein and others, 2001). Stream bed sediment in Frohner Meadows also contains concentrations of arsenic, copper, and lead that exceed consensus-based, probable-effect concentrations (MacDonald and others, 2000).

The U.S. Department of Agriculture Forest Service (USDA Forest Service) identified public lands within the Frohner Meadows area that have been degraded by historical mining and are in need of remediation. To develop effective remediation plans for the wetlands and downstream riparian areas, the USDA Forest Service needed additional information about the distribution of metals in mill tailings, meadow deposits, and stream bed sediment and about the hydrology, hydrogeology, and water quality of the wetlands.

\section{Purpose and Objectives}

This report presents data and interpretations derived from a comprehensive study of the geochemistry of mill tailings, mine waste, meadow deposits, and stream bed sediment and of the hydrology and water quality in the Frohner Meadows area.
The U.S. Geological Survey, in cooperation with USDA Forest Service, conducted this study during 2001 and 2002.

Objectives of the study were to (1) characterize physical and chemical properties of mill tailings and transported mine waste in the meadows, (2) characterize the geochemistry of stream-bed sediment and core samples in the wetlands and waterways of Frohner Meadows and upper Lump Gulch, (3) characterize ground-water flow and quality in the Frohner Meadows area, (4) characterize stream discharge and surfacewater quality in Frohner Meadows and upper Lump Gulch, and (5) identify sources of trace metals and quantify loads of trace metals entering and leaving the meadows. The scope of the study was limited to public lands in Frohner Meadows and upper Lump Gulch that are adjacent to or downstream from the Frohner and Nellie Grant mines.

\section{Description of Study Area}

Frohner Meadows consists of two large wetland areas that are referred to in this report as "upper" and "lower" Frohner Meadows (fig. 2). A small perennial stream connects the two wetlands. The wetland of upper Frohner Meadows occupies an area of about 14.2 acres, is about 1,670 feet ( $\mathrm{ft}$ ) long from north to south, and is at an altitude of about 6,600-6,570 ft. The wetland of lower Frohner Meadows occupies an area of about 15.5 acres, is about $1,750 \mathrm{ft}$ long from west to east, and is at an altitude of about 6,540-6,510 ft. Both wetlands contain several inactive beaver ponds that hold water throughout the 
year. Upper Frohner Meadows receives surface water from several small tributaries. The largest tributary drains into the northwestern part of the upper meadows and informally is named "Frohner Meadows creek." A smaller tributary enters the western part of the upper meadows and is informally named "Nellie Grant creek" (fig. 3). Several tributaries from unmined areas drain from the northern and eastern parts of Frohner Basin into upper Frohner Meadows.

The study area is underlain by granitic rocks of the Boulder batholith (Becraft and others, 1963), which is a very large, composite, Late Cretaceous (80-70 Ma), igneous intrusion that is exposed throughout an area approximately 30 by 60 mi. Near Frohner Meadows, the rocks of the batholith range in composition from quartz monzonite to granodiorite and contain some small, late-stage aplite or alaskite bodies. Rocks of the Elkhorn Mountains Volcanics, which are approximately the same age (81-76 Ma) as rocks in the Boulder batholith, are exposed about 4 mi southeast of the study area. Small rhyolite intrusions and flow remnants are found throughout the northeastern part of the batholith; the nearest exposure is about 1 mi northwest of the study area. Similar intrusive bodies in this part of Montana probably are Eocene or Oligocene in age (40-37 Ma) (Ispolatov, 1997). Rhyolite of the Eocene Lowland Creek Volcanics (53-48 Ma) unconformably overlie exposures of the Elkhorn Mountains Volcanics about $5 \mathrm{mi}$ southeast of Frohner Meadows.

Most historical mining activity in the Frohner Meadows area took place near Frohner Meadows creek and Nellie Grant creek (fig. 2). Mining for base and precious metals was confined to two principal mines, the Frohner mine and the Nellie Grant mine. The mined deposits lie in secs. 14 and 15, T. 8 N., R. $5 \mathrm{~W}$. along a 5- to 40-ft-wide, east-west-trending zone (N. $70^{\circ}$ W., $70^{\circ}-83^{\circ} \mathrm{S}$.) of quartz and chalcedony veins and hydrothermally altered granitic rocks that is more than $0.5 \mathrm{mi}$ long (Becraft and others, 1963). Moderately intense sericitic alteration accompanies mineralization; some clay alteration is present and may be, in part, the result of weathering. Various amounts of calcite are disseminated in altered rocks and in veinlets in the ore zone.

Ore mineralogy differs in these mines. Ore from the Frohner mine contains a variable but significant amount of galena, sphalerite, and arsenopyrite and a subordinate amount of pyrite. Pyrite is the most abundant sulfide mineral in the ore from the Nellie Grant mine, which also contains significant galena and sphalerite and subordinate amounts of chalcopyrite; arsenopyrite was not observed (Becraft and others, 1963).

The Frohner mine was active from the late 1880s to 1954, whereas the Nellie Grant mine was active in the late 1880s through the 1950s and from 1978 to 1982 (Roby and others, 1960; Pioneer Technical Services, 1996). The Frohner mine consists of at least 2,000 ft of tunnels. The extent of underground workings at the Nellie Grant mine is not known. Incomplete estimates for the Frohner mine (1928-54) indicated production of 161 troy ounces (oz) of gold, 7,329 troy oz of silver, 2,305 pounds (lb) of copper, $91,503 \mathrm{lb}$ of lead, and 26,000 lb of zinc from 1,917 tons of ore. The Nellie Grant mine is reported to have produced 293 troy oz of gold, 10,279 troy oz of silver, 3,481 lb of copper, 216,242 lb of lead, and $47,156 \mathrm{lb}$ of zinc from 1,057 tons of ore between 1948 and 1957 (Roby and others, 1960).

Two reduction and concentration mill sites are adjacent to the Frohner and Nellie Grant mines (fig. 2). The Frohner mill originally used gravity concentration, probably with a stamp mill for crushing; the gravity concentration system later was replaced by flotation (Roby and others, 1960). Mill tailings and unprocessed ore from this operation were deposited along the adjacent Frohner Meadows creek in stream terraces, in a debris fan in the northwest corner of upper Frohner Meadows, and in a large area in the central part of upper Frohner Meadows more than $0.5 \mathrm{mi}$ downstream from the mill. Ore from the most recent milling at the Nellie Grant mine (1978-82) was crushed in a ball mill and concentrated by flotation. No information on early ore processing at the Nellie Grant is available. Mill tailings from the Nellie Grant mill are impounded by a small dam on the hillside north of the mill site, are buried on the hillside east of the mill site, are impounded in a large area in the central part of upper Frohner Meadows, and are deposited in a small pond at the west end of lower Frohner Meadows (fig. 3). Reclamation of the Nellie Grant mine site during 1981-83 and in 1993 consisted mostly of recontouring mine waste and mill tailings, controlling ground-water flow to mill tailings, revegetation of mine waste, mill tailings, and reclaimed areas, and erosion control (Pioneer Technical Services, 1996).

Background data for the Frohner Meadows area were obtained from an inventory of abandoned or inactive mines in the Helena National Forest (Metesh and others, 1998) and from records on file at the Montana Department of Environmental Quality, Helena, Mont. Additional information about site characteristics and reclamation activities at the Nellie Grant and Frohner mines was obtained from reports prepared by Pioneer Technical Services, Inc. (Pioneer Technical Services, 1996, 2000).

\section{Geochemistry of Mine Waste and Mill Tailings, Meadow Deposits, and Stream Bed Sediment}

Frohner Basin has been the site of several periods of mining during more than a century; activity focused in the area west of upper Frohner Meadows at the Nellie Grant and Frohner mines. Geochemical investigations were undertaken during this study to (1) describe the chemical and physical character of the mine waste, mill tailings, and unprocessed ore that has accumulated in Frohner Meadows downstream from the mine areas (fig. 3) and (2) understand the effects of the fluvially transported, ore-related trace metals from these mining wastes on the chemistry of stream bed sediment throughout Frohner Meadows. 


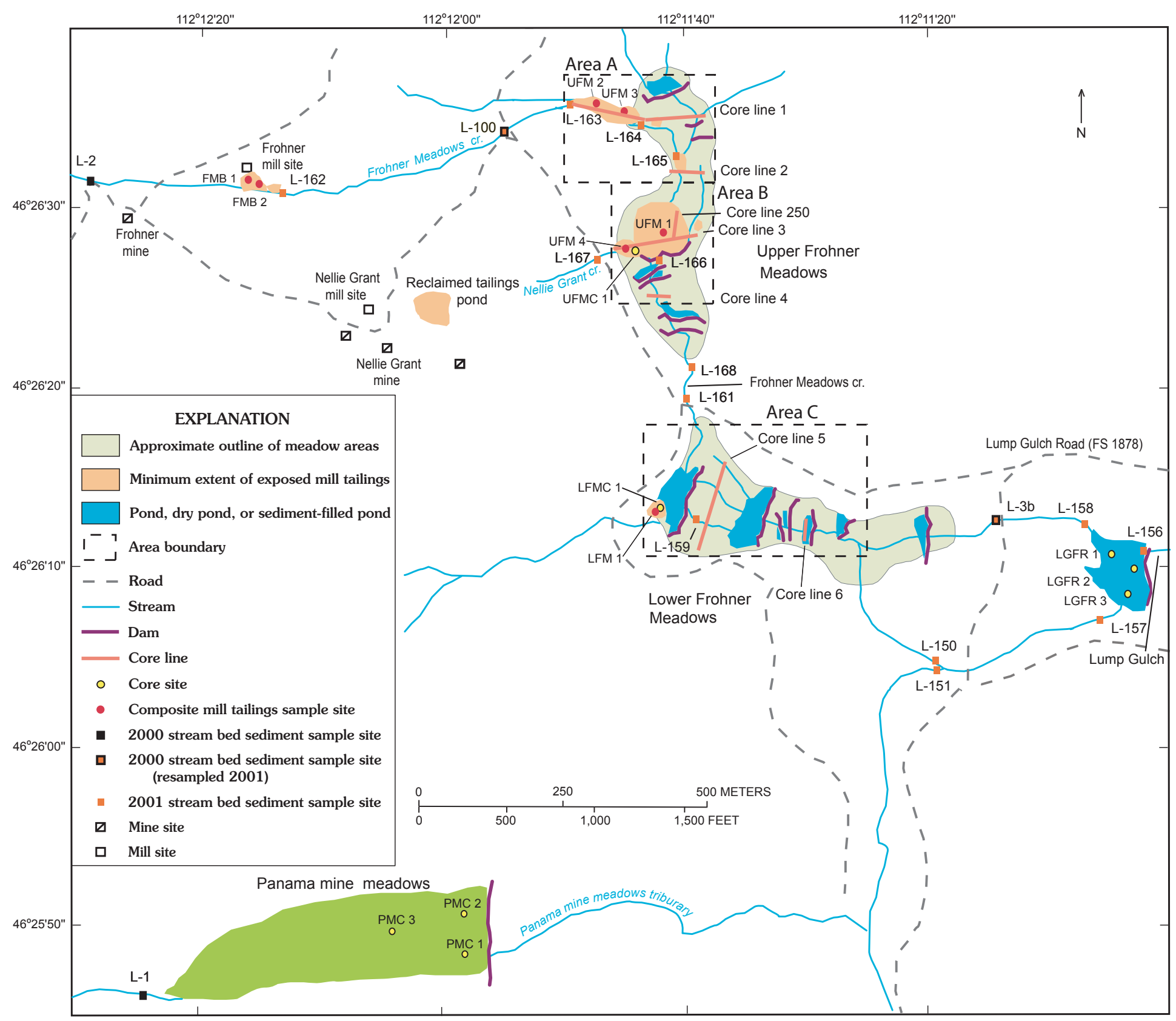

Figure 3. Location of stream bed-sediment, individual core, and composite mill-tailings sample sites and core lines in Frohner Meadows and upper Lump Gulch. 


\section{Field Methods and Sample Preparation}

Stream bed sediment was systematically sampled throughout Frohner Meadows to determine the sources of metals in stream bed sediment at the outlet of the meadows (high concentrations of metal in stream bed sediment had been found during previous regional investigations (Klein and others, 2001)). We also sought to understand the processes that alter metal concentrations in stream bed sediment downstream from the mine area and to determine the contribution of metals in sediment to the metal budget of the meadow system. Most sites were sampled within a 3-day period during July 2001. This short sampling period minimized any seasonal effects on element concentrations owing to changes in stream discharge or water chemistry. Two sites ( $\mathrm{L}-1$ and $\mathrm{L}-2$, fig. 3) were sampled in September 2000 when stream discharge was somewhat lower than it was in July 2001. Methods of sampling and of preparing samples of stream bed sediment are described in Klein, Thamke, and others (2003).

Samples of mine waste and mill tailings samples were collected to determine their bulk chemical composition and acid-producing potential. Surface composite samples were collected at five sites (all but one of the major mill tailings accumulations); samples contained mill tailings mixed with other mine waste (fig. 3). Reclaimed mill tailings at the Nellie Grant mill site were not sampled. Crushed but unconcentrated ore was sampled at two sites (FMB 1 and FMB 2, fig. 3). Material from all sites was collected to a depth of about 3 in. and was composited from 30 or more randomly selected cells throughout the collection site. Sampling methods are described in Klein, Thamke, and others (2003). Data from previous studies of the Frohner and Nellie Grant mine sites (Metesh and others, 1998; Pioneer Technical Services, 1996, 2000) were used to supplement mine-waste and mill-tailings data from this study.

Vertical profiles of mill tailings and mine waste accumulations and meadow deposits obtained from cores in wetland areas were used to help determine the thickness and extent of mill tailings and the stratigraphy, physical character, and chemistry of the mill tailings and meadow deposits. Most cores were $2-5 \mathrm{ft}$ deep and were collected along lines at intervals of 50-100 ft. The locations of profile lines and individual sample sites are shown in figure 3 . The sampling and sample preparation methods used for cores are described in Klein, Thamke, and others (2003).

\section{Laboratory Methods}

Geochemical samples were analyzed by three digestion methods that are described in Klein, Thamke, and others (2003). Resulting solutions were analyzed for 40 elements by inductively coupled plasma-atomic emission spectroscopy (Briggs, 1996). In addition, a fourth digestion method was used to measure net acid-generation potential.

Stream bed sediments, composite samples of surface mine waste and mill tailings, and samples from cores were digested in a mixed four-acid medium of $\mathrm{HCl}, \mathrm{HNO}_{3}, \mathrm{HClO}_{4}$, and HF. This mixed-acid medium dissolves most silicates, oxides, and sulfides; resistant or refractory minerals such as zircon, chromite, and some tin oxides are only partially dissolved. This procedure, referred to as a total digestion, releases the bulk of each major and trace element contained in a sample. Quality-assurance and quality-control data for totaldigestion analyses are summarized in Klein, Thamke, and others (2003, appendix tables 2a-2c).

Stream bed-sediment samples also were analyzed by use of a dilute $\mathrm{HCl}$ and 1 percent hydrogen peroxide partial digestion (dilute-acid partial digestion), which allows the selective determination of trace-metal concentrations bound within certain specific mineral phases. This digestion releases water-soluble and ion-exchangeable metal species from several potentially accumulating phases: hydrous amorphous iron, manganese, and aluminum oxide minerals; some crystalline iron and manganese oxyhydroxides (Church and others, 1993); and water-soluble, ion-exchangeable carbonates. Qualityassurance and quality-control data for this partial digestion by dilute acid is summarized in Klein, Thamke, and others (2003, appendix table 2d).

Composite samples containing surface mine waste and mill tailings were analyzed by the EPA-1312 acidic leach method (U.S. Environmental Protection Agency, 1986) and by a procedure that determines a sample's net acid-generation potential (Lapakko and Lawrence, 1993). Results of this latter method also simulate the net long-term or total potential of a material to produce acid during an unspecified period of weathering. The laboratory procedures for these analyses and the quality-assurance and quality-control data for the EPA-1312 leach are summarized in Klein, Thamke, and others (2003, appendix table 2e).

\section{Mine Waste and Mill Tailings}

\section{Downstream Distribution and Metal Content of Mine Waste and Mill Tailings}

The Frohner and Nellie Grant mine areas are the principal sources of mine waste and mill tailings in Frohner Meadows. A mill was located near each mine (fig. 3), and each mill produced tailings that have accumulated along Frohner Meadows and Nellie Grant creeks. Previous studies found that mine waste and mill tailings at the Nellie Grant and Frohner mines are enriched in potentially toxic metals-arsenic, cadmium, copper, iron, lead, manganese, and zinc (Pioneer Technical Services, 1996, 2000).

Between the Frohner mill and upper Frohner Meadows, tailings were deposited in small stream terraces along Frohner Meadows creek and in a mill-tailings debris fan at the change in slope where the stream enters upper Frohner Meadows. Below this debris fan, the creek has distributed mill tailings widely (fig. 3, area A) in the upper part of upper Frohner Meadows. The creek also transported a substantial amount of 
mill tailings to a mill-tailings impoundment in the middle of upper Frohner Meadows (fig. 3, area B).

Most mill tailings from the Nellie Grant mine were impounded in a tailings pond (fig. 3) on the hillslope above upper Frohner Meadows, but some were transported into upper Frohner Meadows by Nellie Grant creek. Some mill tailings from the Nellie Grant mine also were discharged into a beaver pond in lower Frohner Meadows (Pioneer Technical Services, 1996) during the latest period of mining (1979-82).

Seven composite surface samples from mill-tailings accumulations in upper and lower Frohner Meadows were collected to determine the chemical composition and acidproducing potential of the tailings. These samples were collected from each of the three major mill-tailings accumulations: at the west edge of the Frohner mill-tailings debris fan (area A), at the main mill-tailings impoundment (area B), and at the mill-tailings delta in the western margin of lower Frohner Meadows (fig. 3). In addition, shallow cores were drilled in these areas (Klein, Thamke, and others, 2003, and described in the following section, "Meadow Deposits"), and chemical analyses of mill tailings in the cores were used to investigate chemical differences among different sources of mill tailings. Two samples were also collected from dispersed untreated ore at the Frohner mill site (fig. 3, area A). Data from previous studies of the Frohner and Nellie Grant mine sites (Metesh and others, 1998; Pioneer Technical Services, 1996, 2000) were used to supplement chemical analyses of mill tailings and mine waste obtained during this study. Selected analyses from the previous studies, as well as the results of the total-digestion analyses of the composite samples from this study, are summarized in Klein, Thamke, and others (2003).

Some variation in composition of mill tailings and mine waste at these two mine sites is apparent. A ternary diagram of arsenic, lead, and zinc concentrations that uses data from surface mine waste and mill tailings and the mill tailings collected in cores (tables 6 and 7 of Klein, Thamke, and others, 2003 ) illustrates the compositional variability of mine waste and mill tailings (fig. 4). The position of each point on the diagram marks the proportion of each metal to the total concentration of the three metals; the position is found by dividing the concentration of each metal by the total concentration of

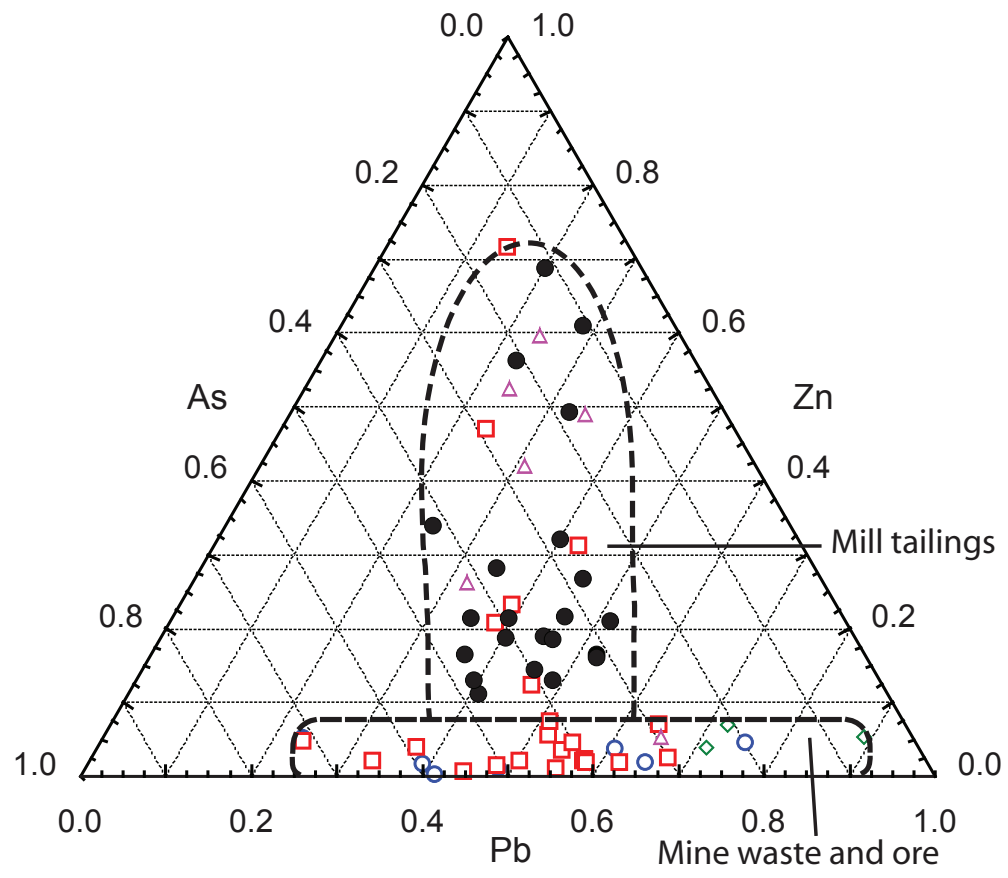

\section{EXPLANATION}

- Frohner mine unprocessed ore

- Area A mill tailings

- Nellie Grant mine waste

$\triangle$ Nellie Grant mill tailings

- Area B mill tailings

Figure 4. Total concentrations of arsenic, lead, and zinc in mine waste, unprocessed ore, and mill tailings from Frohner Meadows area. Areas referred to are shown in figure 3. 
the three metals. These three ore-related metals are sufficient to illustrate the variability, because copper is a minor constituent at the Frohner and Nellie Grant mines and because the chemical behavior of cadmium is nearly identical to that of zinc. Stream bed sediment in Frohner Meadows and upper Lump Gulch is also highly enriched in arsenic, lead, and zinc. Unprocessed ore and mine waste from the Frohner mill are distributed near the lead axis; arsenic/(lead + arsenic) values range from 0.25 to about 0.75 . The proportion of zinc to the total of the three metals in these samples was very low (0.05 or less). Waste rock from the Nellie Grant mine had a lower arsenic/(lead + arsenic + zinc) value than that of most of the unprocessed ore samples from the Frohner mill and waste rock from the Frohner mine; that value ranged from approximately 0.05 to 0.25 . The proportion of zinc to total metal content in samples of Nellie Grant mine waste was similar to that found in unprocessed ore and mine waste from the Frohner mill and mine. The area labeled "mine waste and ore" in figure 4 is defined by these samples.

Many samples from area A below the Frohner mine and mill (fig. 3) plotted within the mine waste and ore field (fig. 4); this distribution suggests that the samples were predominantly transported mine waste and unprocessed ore (fig. 4). Approximately 30 percent of the samples from area A showed a high but variable proportion of zinc. These samples were from cores in the most distal part of deposits that were sampled in area A; points plotted for these samples form a group that trends toward the zinc corner of the ternary diagram. These samples were composed of sand- and silt-size mill tailings, and their enrichment in zinc probably is due to entrainment of zinc in mill effluent during gravity ore processing at the Frohner mill. Samples of mill tailings in area B plotted in the same part of the diagram as did mill tailings from area A. Most of the samples of mill tailings from the Nellie Grant mill on the west side of area B (fig. 3), from the Nellie Grant mill tailings pond (now reclaimed), and from lower Frohner Meadows (one sample) were similar to most samples of mill tailings from other accumulations in Frohner Meadows (fig. 4). One sample plotted with those that form the mine waste and ore field and probably was waste deposited with tailings. The mill-tailings field is defined by these samples where they take proportions less than the maximum zinc proportion found in ore samples and mine waste (fig. 4).

As compared with mine waste and unprocessed ore samples, many surface and core samples from Frohner Meadows were enriched in zinc. This enrichment was most likely due to the recovery, during the extraction process, of lead and silver from galena $(\mathrm{PbS})$ and of arsenic from either arsenian pyrite $\left(\mathrm{FeS}_{2}\right)$ or arsenopyrite (FeAsS). Early milling processes enriched tailings in zinc (from sphalerite, $\mathrm{ZnS}$ ), because zinc was not recovered efficiently in gravity separation mills such as the Frohner mill. Zinc was recovered only later by mills that used flotation. However, as late as 1982 zinc was still poorly recovered. Mill tailings continued to be enriched in zinc, even though flotation was used at the Nellie Grant mill, which produced the youngest mill tailings in lower Frohner Meadows (Pioneer Technical Services, 1996).

The ternary diagram that shows concentrations of arsenic, lead, and zinc (fig. 4) is useful in defining the provenance of the surface and subsurface samples from Frohner Meadows. Determining whether a sample is predominantly ore and mine waste or whether it is mill tailings is useful in predicting which metals are most likely to be contributed to surface or ground water and stream bed sediment in a given area.

\section{Acid-Generating Capacity and Leachability of Mine Waste and Mill Tailings}

Two important characteristics of mine waste are its ability to produce acid and to release soluble metals. The composite mine-waste samples were tested to determine both. In the procedure used to determine the potential net acid production (NAP) (described in Klein, Thamke, and others, 2003), an aliquot of each sample was exposed to a strong (30 percent) solution of hydrogen peroxide. Sulfide minerals (typically pyrite, $\mathrm{FeS}_{2}$ ) in the sample were oxidized during the digestion and produced sulfuric acid. The results are expressed in terms of the concentration of calcium carbonate $\left(\mathrm{CaCO}_{3}\right)$ in kilograms per metric ton that would be required to neutralize the resultant acid. The result is a net estimate of the total acid that the sample could produce during an unspecified period of time, because it takes into account potential neutralization by acid-consuming minerals and the continuous generation of acid as weathering and transport remove previously generated acid. The NAP of a material is the simple difference between its acid-producing potential and its acid-neutralizing potential. This difference can be determined by separately measuring each attribute in the laboratory and taking the difference or by measuring one solution in which acid is both produced and neutralized by the sample itself, as was done for this study.

Results of the NAP test showed a range of values from 2 to $250 \mathrm{~kg} / \mathrm{ton}$ (table 1). Other studies applied this procedure to mine-waste material from the Boulder River watershed west of Frohner Meadows and to material from the Animas River watershed in southwestern Colorado (Fey, Desborough, and Finney, 2000; Fey, Nash, and others, 2000). Results from 19 samples from the Boulder River watershed ranged from 0 to $34 \mathrm{~kg} / \mathrm{ton}$, and results from 110 samples from the Animas River watershed, Colorado, ranged from 0 to $167 \mathrm{~kg} / \mathrm{ton}$. By comparison, the fine-grained sample from the mill-tailings delta at the west end of lower Frohner Meadows (sample LFM 1 NGS) had an extremely high NAP. Another measure of the acid-producing qualities of a mine-waste material is known as the "neutralization potential ratio," which is the ratio of the neutralization potential to the acid-producing potential, where again each potential is measured separately. There are several classification schemes for the neutralization potential ratio, and a given mine-waste material can be placed into various categories. According to one classification scheme by Price and others (1997), four categories can be used to relate the neutralization potential ratio to the likelihood that a waste 
material will produce acid. These categories are as follows: ratio $<1$, acid production likely; ratio between 1 and 2, acid production possible; ratio between 2 and 4, acid-production potential low; and ratio $>4$, no acid-production potential. The fourth category can be obtained by mixing four parts of limestone with one part of mine waste (a 4:1 ratio). For example, to remediate a sample with a NAP of $10 \mathrm{~kg} / \mathrm{ton}$ would require mixing in $40 \mathrm{~kg} /$ ton $\mathrm{CaCO}_{3}$ into the material, or about 170 $\mathrm{lb}$ of limestone per cubic yard of waste. Samples FMB 1 and LFM 1 NGS (table 1) had NAP values high enough to make it impractical to apply and mix limestone on-site: LFM 1 NGS would require more than $4,000 \mathrm{lb}$ of limestone per cubic yard (about a 50 percent mix of limestone with waste). In addition, this site is under water, which makes it exceedingly impractical to remediate.

All other samples except UFM 2 had relatively low NAP values. Three splits of sample UFM 2 were analyzed for acidity $-\mathrm{a}>2$-mm fraction, a $<2$-mm fraction, and a combined bulk fraction. Most geochemical studies find that the finer fractions contain more of the constituents of interest (Horowitz, 1991). Such was not the case for acidity in UFM 2 . The $>2-\mathrm{mm}$ fraction yielded an NAP value more than 10 times that of the $<2$-mm fraction and more than twice that of the bulk fraction. This sample contained coarse, angular quartz chips that we interpret to be coarsely ground ore material from which pyrite and other sulfide minerals were not fully liberated.

However, the sample preparation process for this study (grinding to $<200$ mesh) allowed all pyrite to be available for reaction in the acidity determinations. Thus, the NAP value obtained from the $>2$-mm fraction was a high estimate of the total potential of the $>2-\mathrm{mm}$ fraction to create acid. The value obtained from the $<2-\mathrm{mm}$ fraction, only $2 \mathrm{~kg} / \mathrm{ton}$, indicates few acid-storing soluble salts or pyrite in the fine fraction. The bulk sample yielded a value $(12.8 \mathrm{~kg} / \mathrm{ton})$ between that of the $<2-\mathrm{mm}$ and the $>2-\mathrm{mm}$ fractions. All three fractions, when subjected to the EPA-1312 leach (see below), produced leachates having a $\mathrm{pH}$ between 3.5 and 3.7. The $\mathrm{pH}$ of the leach solutions represents a snapshot of the hydronium-ion activity, whereas the NAP represents the long-term potential for generation of acid.

The leachability of various constituents from the composite mine waste and mill tailings samples was determined by the EPA-1312 synthetic precipitation leach procedure (SPLP) described in Klein, Thamke, and others (2003). This procedure simulates the effect of rainfall or runoff on a dump surface. Note that in the discussion that follows, the term "leachable" applies to constituents liberated by the SPLP test solution, which is deionized water acidified to $\mathrm{pH} 4.2$, and not to those liberated by the dilute-acid partial digestion that was applied to stream bed sediment. The leachate was analyzed for the ore-related metals arsenic, cadmium, copper, lead, and zinc. The sum of the concentrations of these five metals in the leach solution is plotted against the NAP value obtained from the acidity test shown in figure 5. This plot provides a geochemical rank for each waste and tailings source. This rank should be considered, along with factors such as amount of material, proximity to flowing water, permeability of the substrate, and slope aspect, to determine appropriate remediation actions.

The diagram in figure 5 is divided into four geochemical classes that are based on the classification of Fey, Desborough,

Table 1. Net acid-producing capacity of mine waste and mill tailings (kilograms per ton $\mathrm{CaCO}_{3}$.

$[<$, less than; $>$, more than $]$

\begin{tabular}{lcc}
\hline \multicolumn{1}{c}{$\begin{array}{c}\text { Sample } \\
\text { number }\end{array}$} & Description & $\begin{array}{c}\text { Acid-producing } \\
\text { capacity }\end{array}$ \\
\hline FMB 1 & Frohner mill & Composite ore sample \\
FMB 2 & Composite ore sample & 38 \\
& Lower Frohner Meadows & 7.2 \\
LFM 1 NGS & Nellie Grant mill-tailings delta & 250 \\
& Upper Frohner Meadows & \\
& Mill-tailings debris fan & \\
UFM 1 & Eastern part, bulk sample & 3.1 \\
UFM 2 (bulk) & Western part, bulk sample & 12.8 \\
UFM 2 (>2-mm fraction) & Western part, >2-mm fraction & 35 \\
UFM 2 (<2-mm fraction) & Western part, <2-mm fraction & 2 \\
UFM 3 & Main mill-tailings area & 4.3 \\
UFM 4 & Nellie Grant mill-tailings fan & 2.8 \\
\hline
\end{tabular}


and Church (2000). Class 1 contains material that generates little acid $\left(<10 \mathrm{~kg} /\right.$ ton $\left.\mathrm{CaCO}_{3}\right)$ and low concentrations of total leachable metals $(<1,000 \mu \mathrm{g} / \mathrm{L}$ total metals). Class 2 contains material that generates little acid and moderate total leachable metals. Class 3 contains material that generates little acid but high concentrations of total leachable metals. Class 4 contains material that generates large amounts of acid and high concentrations of total leachable metals $\left(>10 \mathrm{~kg} /\right.$ ton $\mathrm{CaCO}_{3}$ and $>5,000 \mu \mathrm{g} / \mathrm{L}$ total leachable metals). If other factors are equal, class 4 materials then are of highest concern, whereas class 1 materials are of lowest concern.

Two composite unprocessed crushed-ore samples were collected at the Frohner mill site (fig. 3). Sample FMB 1 was collected from the ground below the mill, and sample FMB 2 was collected from an above-ground bin. Both samples yielded SPLP leachates with geochemistry similar to each other (Klein, Thamke, and others, 2003); lead dominated the total dissolved-metal concentrations $(13,000$ and 19,000 $\mu \mathrm{g} / \mathrm{L}$ total leachable metals, respectively). However, the NAP values obtained from the two samples were different. Sample FMB 1 had an NAP value of $38 \mathrm{~kg} /$ ton $\mathrm{CaCO}_{3}$, whereas sample FMB 2 had an NAP value of $7 \mathrm{~kg} /$ ton $\mathrm{CaCO}_{3}$. This difference may relate to the composition of source material or to differences in the response of source materials to weathering. Regardless of the acidities, both unprocessed ore samples produced leachates having high concentrations of dissolved metals.

Sample UFM 1 was collected at the upper (western) end of fluvial mill tailings deposited in Frohner Meadows creek as it entered upper Frohner Meadows (fig. 3). This sample produced a moderate $2,700 \mu \mathrm{g} / \mathrm{L}$ total leachable metals. The low NAP value $\left(3.1 \mathrm{~kg} /\right.$ ton $\left.\mathrm{CaCO}_{3}\right)$ indicates that little pyrite was present to produce acid.

Sample UFM 2 was collected in upper Frohner Meadows (fig. 3, area A) and was separated into three size categories as described previously. The different size fractions responded quite differently to acidity and SPLP tests. The bulk sample and the $>2-\mathrm{mm}$ fraction plotted in class 4 (fig. 5). The $<2-\mathrm{mm}$ fraction, however, plotted in class 2 . These mill tailings, which probably had been processed by an early stamp mill, still contained many coarsely crushed quartz chips. Despite its coarse grain size, the coarse fraction produced a high concentration of lead $(17,000 \mu \mathrm{g} / \mathrm{L})$ and a low concentration of zinc (330 $\mu \mathrm{g} / \mathrm{L})$. The sample of $<2-\mathrm{mm}$ material produced only 1,300 $\mu \mathrm{g} / \mathrm{L}$ lead but a slightly higher zinc concentration of $570 \mu \mathrm{g} / \mathrm{L}$, which indicates that the coarse fraction of the mill tailings was the source of the high concentrations of metals and high acid concentration in the bulk sample.

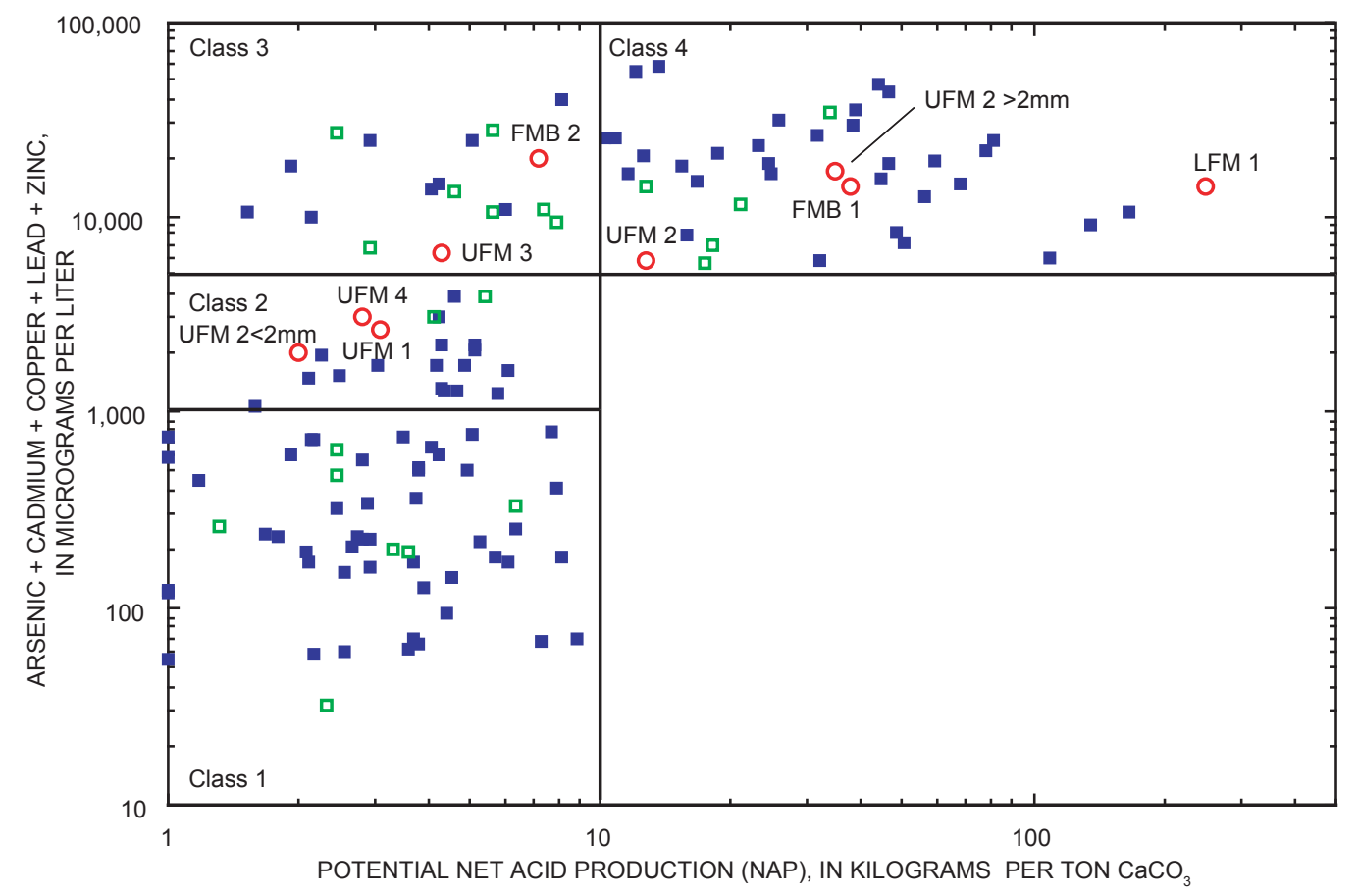

EXPLANATION

- Animas watershed (Fey, Desborough, and Finney, 2000)

- Boulder watershed (Fey, Desborough, and Church, 2000)

○ Frohner Meadows

Figure 5. Acid-generating capacity and yields of ore-related metal in mine waste and mill tailings from Frohner Meadows area and from two other mine sites. 
Composite sample UFM 3 contained some fluvial mill tailings similar to the coarse-grained material in sample UFM 2. It was collected in upper Frohner Meadows throughout the relatively large main mill tailings area upstream from UFM 2 in (fig. 3, area A); tailings samples were collected from overbank material that had been transported down Frohner Meadows creek. The total dissolved metals $(6,500 \mu \mathrm{g} / \mathrm{L}$, dominated by zinc) placed this sample in class 3 . This sample also produced the second-highest concentration of dissolved cadmium $(73 \mu \mathrm{g} / \mathrm{L})$.

Sample UFM 4, collected from the mill tailings debris fan on Nellie Grant creek (which drains the Nellie Grant mine area) on the west side of upper Frohner Meadows, produced a leachate having the lowest $\mathrm{pH}$ and highest specific conductance of all the samples. However, the amount of total dissolved metals was moderate $(3,200 \mu \mathrm{g} / \mathrm{L}$, dominated by zinc), and the net acid production was the second lowest. This material probably has a higher proportion of soluble salts and a lower concentration of pyrite than the others.

Sample LFM 1, taken from the fine-grained mill tailings in the delta of the pond in lower Frohner Meadows (fig. 3, area C), produced a leachate with the highest arsenic, cadmium, and zinc concentrations $(900,170$, and 9,100 $\mu \mathrm{g} / \mathrm{L}$, respectively) of the samples from the study area. This material is probably a source of some of the solution-transported arsenic that enriches stream bed sediment downstream at site $\mathrm{L}-159$ (see below).

\section{Meadow Deposits}

Frohner Meadows is covered by thick vegetation, many shallow beaver ponds, and fine-grained pond-fill deposits that now are exposed in breached beaver ponds. Mill tailings have been impounded behind several beaver ponds, and many areas that contain a substantial thickness of mill tailings are obvious from their lack of vegetation. However, in other areas mill tailings may be covered by thick vegetation. In these areas, mill tailings commonly are concealed by thin, organic-rich soil and are difficult to identify. In some ponds where water levels have decreased owing to breaches in inactive beaver dams or low water flow, fine-grained pond-bottom deposits commonly are difficult to distinguish from transported finegrained mill tailings.

A reconnaissance coring program was undertaken throughout Frohner Meadows to determine (1) the stratigraphy of the meadow deposits including exposed tailings, (2) the extent, thickness, and chemical composition of buried mill tailings, and (3) the degree of subsurface metal migration after deposition. Twenty-seven cores were collected in upper Frohner Meadows and nine were collected in lower Frohner Meadows. Three cores were also taken in meadow deposits in a nearby valley, referred to informally as the "Panama mine meadows" (fig. 3). This area has no obvious significant mining or milling activity; it was sampled to help establish background concentrations for the study area and to determine the origin of the deposits filling an abandoned reservoir in Panama mine meadows. Cores were obtained July 16-19, 2001; core lengths were $33-133 \mathrm{~cm}$. Sampling methods and data from these core samples are discussed in Klein, Thamke, and others (2003); geographic locations and other site data are presented in appendix 1a of that report, core descriptions and location of intervals sampled for chemistry are presented in appendix $1 \mathrm{~b}$ of that report, and the results of chemical analyses of the sampled intervals, obtained by use of the total-digestion method, are listed in table 7 of that report.

\section{Premining Metal Concentrations in Frohner Meadows}

Frohner Meadows has been formed from fill material, some of which certainly is derived locally. Part of this mostly alluvial fill may have been derived from stream bed sediments that were shed by metal-bearing natural exposures of the Frohner-Nellie Grant vein system and by weakly mineralized rocks that typically surround these vein systems. This stream bed sediment likely would have contained higher concentrations of ore-related elements than stream bed sediment from sites in drainage basins that have been affected little (or not at all) by mining or by natural exposures of mineral deposits.

Establishment of local, premining concentrations of ore-related elements allows the determination of the degree to which postmining stream bed and pond-fill deposits are enriched in metals; such a baseline is necessary to establish baseline concentrations that are relevant to remediation goals. The area of concern in this study is the area drained by Frohner Meadows creek, the upper part of Lump Gulch Creek, and Panama mine meadows. To estimate premining concentrations, samples were selected from cored intervals that appeared to be geologically or geographically isolated from mining-derived deposits. These samples were chosen from areas that contain no physical signs of previous mining activity (Panama mine meadows) or from core intervals that are separated from overlying mine waste and mill tailings by thick clay layers. The samples used to define the premining metal concentrations in Frohner Meadows and their chemical analyses are tabulated in Klein, Thamke, and others (2003).

Cores from Frohner meadows contained clay-rich deposits and coarse clastic deposits. Clay-rich deposits formed during sedimentation that filled in shallow ponds and marshes. Sandy or coarse alluvium formed in stream channels or as overbank deposits along ancient stream channels. The postdepositional environment of these two types of deposits may differ geochemically because of their different physical and hydrological characters. In order to determine if background concentrations differ in these two environments, metal concentrations determined in clay-rich samples were compared statistically with those in coarse clastic deposits.

The population distribution of the metals arsenic, cadmium, copper, lead, and zinc were compared with calculated normal distribution curves. Zinc populations were normally distributed, but populations of the other four metals were not. The nonparametric Mann-Whitney $U$ test was used to 
compare the metal populations in samples of these two deposit types (clay rich and coarse clastic). This test equally rigorously compares two normally distributed or two nonnormally distributed populations. The results of this test indicate that the metals concentrations of both groups were statistically similar ( $\mathrm{p}<0.05$ ) and can be combined to estimate premining concentration levels. A summary of the descriptive statistics for background samples from the two groups is shown in table 2.

Trace-element chemistry of stream bed sediment and other geologic materials was investigated in the nearby Boulder River watershed (Church and others, 2004). The Boulder River watershed lies immediately west of the upper Prickly Pear Creek watershed, which contains the Frohner Meadows study area. The Boulder River and Prickly Pear Creek watersheds have similar bedrock geology and glacial history, and they contain similar types of mineral deposits.

As part of the Boulder River watershed study, 16 sites were sampled to determine premining metal concentrations in stream bed sediment and terrace deposits downstream from areas that were mined or mineralized. Means and standard deviations of the Boulder River data are shown in table 2, as are similar data for core samples of meadow-fill deposits in Frohner Meadows. Concentrations of lead and zinc were substantially higher in premining samples from Frohner Meadows than in premining samples from the Boulder River watershed or mean global soil and sediment concentrations. However, arsenic and copper concentrations in premining samples from Frohner Meadows were similar to concentrations of those elements in the Boulder River watershed and were substantially higher than mean global soil and sediment concentrations. Premining samples from Frohner Meadows and Boulder River watershed contained, as shown by the Mann-Whitney $U$ test, similar arsenic, cadmium, and copper concentrations but different lead and zinc concentrations $(\mathrm{p}<0.05)$. These results strongly suggest that locally derived premining metal concentrations should be used as baseline values for the Frohner Basin. Arsenic concentrations in these samples were high relative to global-mean sediment and soil concentrations but were similar to premining background concentrations in the Boulder River watershed, a relationship that suggests that both watersheds possess regional high background concentrations of arsenic.

Calculation of geochemical threshold concentrations is a technique commonly used in exploration geochemistry to identify anomalous samples. Geochemical threshold concentrations presented in table 2 were calculated from the cores by using the mean concentration of each metal plus two standard deviation concentrations, a widely accepted method (Rose and others, 1979). These threshold values are used to identify sample intervals in Frohner Meadows cores that had metal concentrations likely to be truly anomalous (the core interval was enriched) and not merely in the upper range of normal values.

\section{Postdepositional Metal Migration}

Vertical chemical profiles were plotted for several cores to investigate the vertical variation in concentration of metals and related elements. From each core, six samples were taken between 5 and $85 \mathrm{~cm}$ depth and were analyzed to provide data for these plots. These plots reveal two types of profiles. The first is illustrated by a core from site 1-150 (fig. 6) in and the second is illustrated by a core from site 3-250 (fig. 7). These samples are located the western part of core line 1 (fig. 8) and the central part of core line 3 (fig. 9), respectively.

The upper part of the core from site 1-150 was a coarse mixture of oxidized fluvial mill tailings, unprocessed ore or mine waste, and transported colluvial granitic material (slope wash) that overlay a thin meadow soil of interfingered peat, silt, and fine tailings. The lower part of the core was an interval of interlayered alluvial deposits and transported granitic alluvial and colluvial deposits (fig. 10). The chemical profile of this core showed high concentrations of one group of metals (arsenic, copper, iron, and lead) in the upper two samples (mill tailings and mine waste); concentrations were lower and declined in the underlying transported colluvial material, meadow soil, and the mixed layer of transported colluvium and alluvium (fig. 6). The highest concentrations of this first

Table 2. Means and standard deviations of ore related-metal concentrations in core samples used to define premining conditions in study area.

[All concentrations are total. Frohner Meadows geochemical threshold is premining concentration plus two standard deviations. Mean global sediment and soil concentrations are from Bowen (1979). Boulder River concentrations are from Church and others (2004). Cadmium concentrations below detection limit ( $2 \mathrm{ppm}$ ) in Frohner Meadows were assigned a concentration of $1 \mathrm{ppm}$ for calculating the mean. All concentrations are in parts per million; standard deviations are in parentheses; <, less than; (-), below detection limit]

\begin{tabular}{|c|c|c|c|c|c|}
\hline Metal & $\begin{array}{c}\text { Frohner } \\
\text { Meadows } \\
\text { premining } \\
\text { concentration }\end{array}$ & $\begin{array}{c}\text { Frohner } \\
\text { Meadows } \\
\text { geochemical } \\
\text { threshold } \\
\text { concentration }\end{array}$ & $\begin{array}{l}\text { Boulder River } \\
\text { watershed } \\
\text { premining } \\
\text { concentration }\end{array}$ & $\begin{array}{l}\text { Mean global } \\
\text { sediment } \\
\text { concentration }\end{array}$ & $\begin{array}{l}\text { Mean global } \\
\text { soil } \\
\text { concentration }\end{array}$ \\
\hline Arsenic & $58(32)$ & 122 & $58 \quad(57)$ & 8 & 6 \\
\hline Cadmium & $2.2(1)$ & 4.2 & $<2 \quad(-)$ & 0.05 & 0.35 \\
\hline Copper & $42(21)$ & 84 & $59 \quad(32)$ & 33 & 30 \\
\hline Lead & $114(86)$ & 286 & $79 \quad(55)$ & 19 & 35 \\
\hline Zinc & $232(67)$ & 366 & $159 \quad(52)$ & 95 & 90 \\
\hline
\end{tabular}




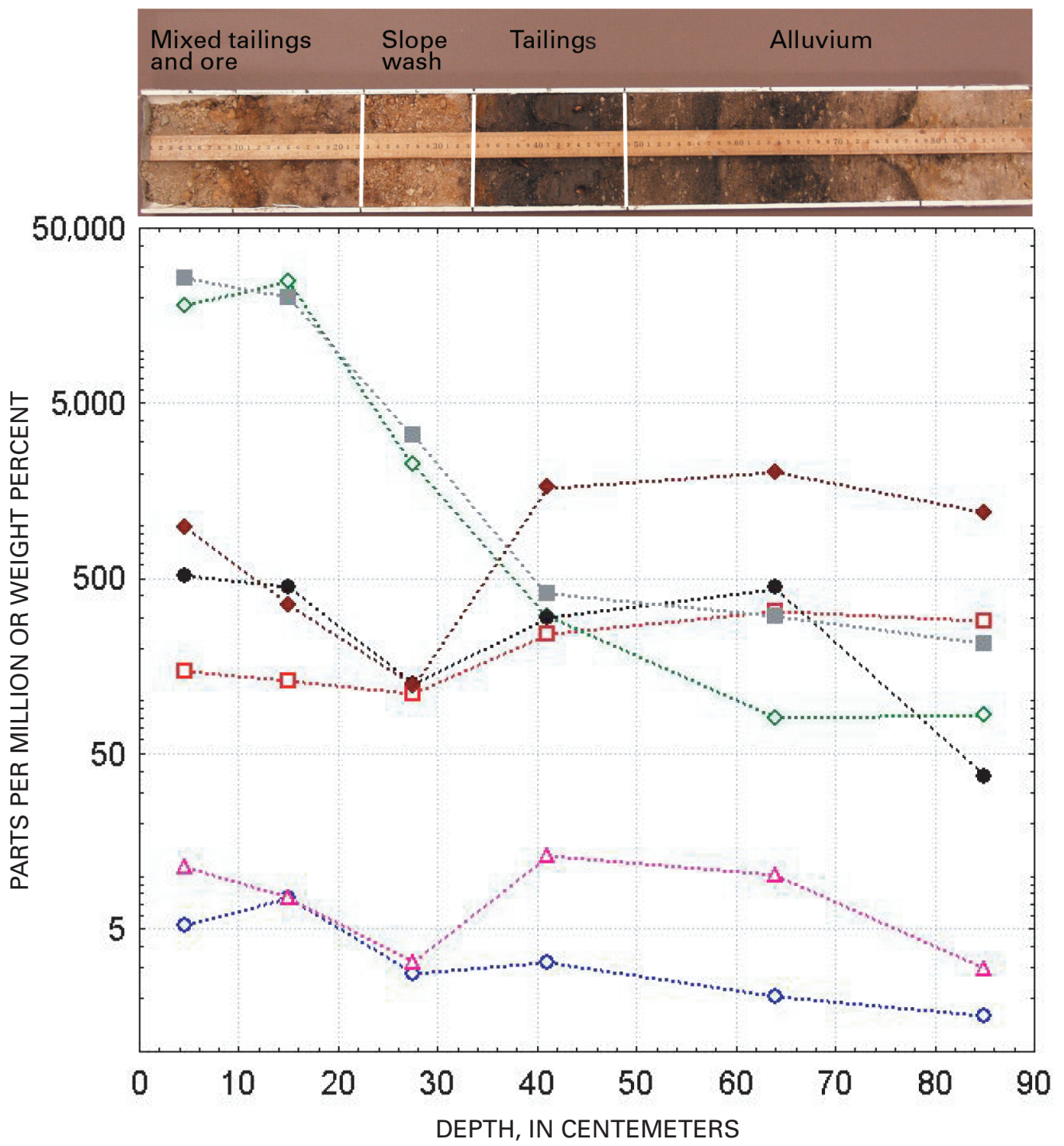

EXPLANATION

.o... Fe wt \%

- $\cdots$ Mn ppm

. $\cdots$ As ppm

$\cdots$ Cd ppm

$\cdots \cdots$ Cu ppm

..... $\mathrm{Pb} \mathrm{ppm}$

*.. Zn ppm

Figure 6. Composite image and geochemical profile of core 1-150 showing relation between stratigraphy and chemistry. Depths not corrected for compaction. ppm, parts per million; wt \%, weight percent. 


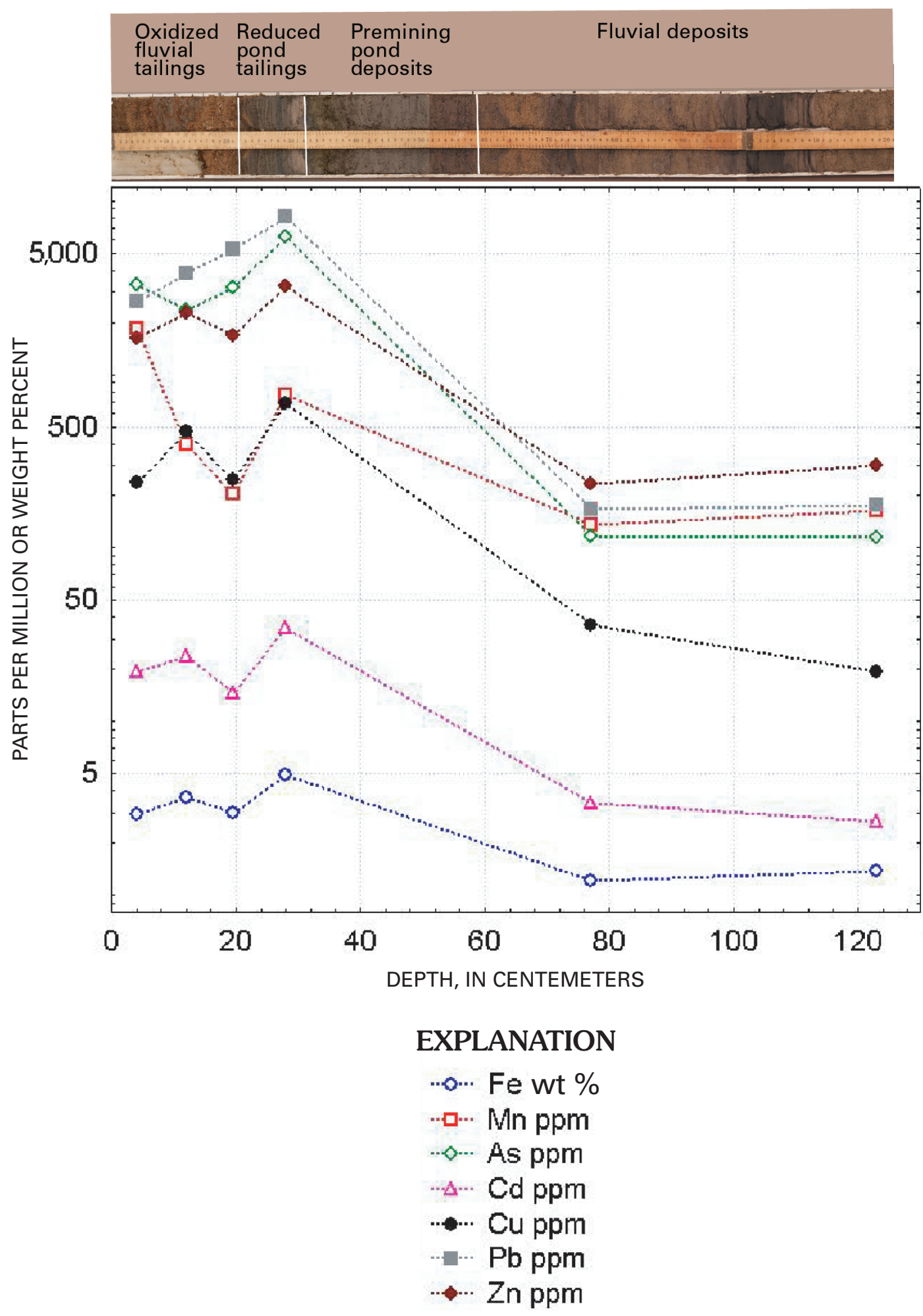

Figure 7. Composite image and geochemical profile of core 3-250 showing relation between stratigraphy and chemistry. Depths not corrected for compaction. ppm, parts per million; wt \%, weight percent. 


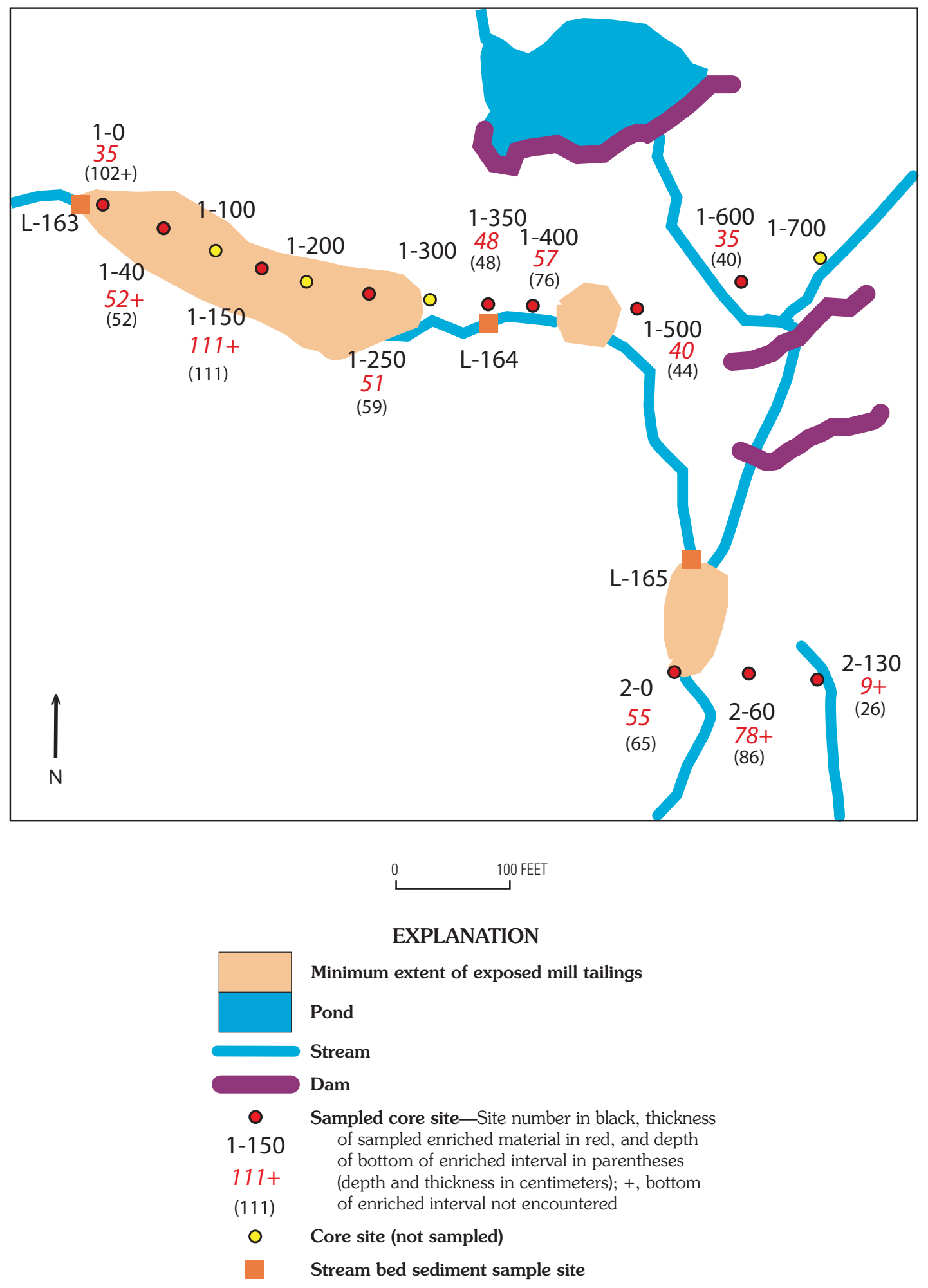

Figure 8. Upper mill-tailings area (fig. 3 , area A, upper Frohner Meadows) showing thickness of metalenriched material and depth to bottom of enriched interval. 

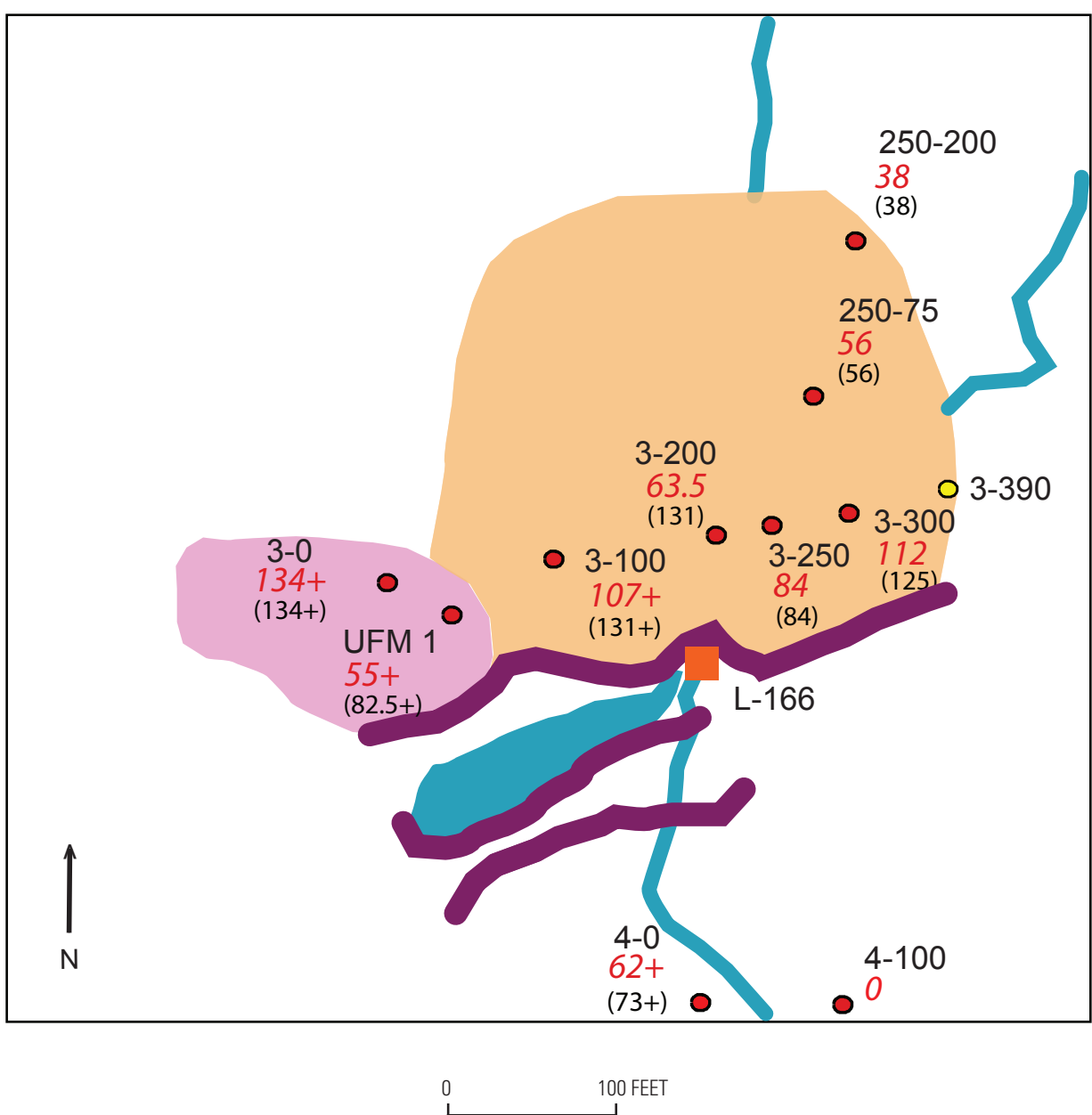

\section{EXPLANATION}

\begin{tabular}{|c|c|}
\hline & \multirow{3}{*}{$\begin{array}{l}\text { Minimum extent of exposed mill tailings } \\
\text { Approximate extent of Nellie Grant tailings debris fan } \\
\text { Pond }\end{array}$} \\
\hline & \\
\hline & \\
\hline & Stream \\
\hline & Dam \\
\hline $\begin{array}{c}0 \\
3-0 \\
134+ \\
(134+)\end{array}$ & $\begin{array}{l}\text { Sampled core site-Site number in black, thickness } \\
\text { of sampled enriched material in red, and depth } \\
\text { of bottom of enriched interval in parentheses } \\
\text { (depth and thickness in centimeters); +, bottom } \\
\text { of enriched interval not encountered }\end{array}$ \\
\hline O & Core site (not sampled) \\
\hline 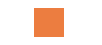 & Stream bed sediment sample site \\
\hline
\end{tabular}

Figure 9. Main mill tailings area (fig. 3, area B, upper Frohner Meadows) showing thickness of enriched material and depth to bottom of enriched interval. 
group of metals (arsenic, copper, iron, and lead) were similar to concentrations of these metals in ore from the Frohner mine. Concentrations of a second group of metals (cadmium, manganese, and zinc) were lowest in the upper two samples; the concentrations of these metals generally increased with depth between $26.5 \mathrm{~cm}$ and approximately $64 \mathrm{~cm}$. Cadmium, manganese, and zinc concentrations also were typically high in local unprocessed ore and mine waste and would, therefore, be expected to be high in mill tailings (as in fact was seen in bulk samples from the study area; Klein, Thamke, and others, 2003, table 6). However, the concentrations of these three metals generally were lower in the mill tailings in the upper part of this profile than in the underlying deposits. The difference in the profiles of these two groups of metals can be explained by their chemical behavior during weathering and by the mixing of ore-related material (mill tailings, ore, and mine waste) with eroded sediments that contain lower background concentrations of metals.

Geochemically, arsenic, iron, and lead are relatively immobile after weathering and oxidation of the sulfide ore minerals, and the abundance of these elements in the profile is related to their original concentrations in the mill tailings. Reduction in their concentrations can be attributed primarily to mixing with geologic material having lower concentrations of background metals. In contrast, cadmium and zinc are geochemically mobile in oxidizing environments; their concentrations are moderate at the top of this profile and increase with depth. This distribution probably reflects oxidation of sulfide minerals in mill tailings and mine waste, dissolution of cadmium and zinc in the upper parts of the profile during weathering and subsequent deposition, and their concentration at deeper levels by precipitation or sorption. The metals might be carried in downward percolating water or be laterally transported by water in permeable subsurface material. Copper shows relatively little change through the profile. Concentrations of all of these metals were markedly reduced in the slope wash $(28 \mathrm{~cm}$ depth) probably because they were diluted by a large amount of transported granitic colluvium.

Contrasting geochemical behavior was shown in the core from site 3-250 near the middle of core line 3 (fig. 3 ). This core consisted of oxidized fluvial mill tailings that overlay a relatively thin layer of reduced, bedded, fine-grained mill tailings (fig. 7). These fine-grained mill tailings in turn overlay clay-rich, highly organic premining pond-fill deposits and fluvial deposits. The highest concentrations of arsenic, cadmium, copper, lead, and zinc were present in the reduced mill tailings (fig. 7). The later addition of fluvial material having only background concentrations of metals diluted the reduced mill tailings and produced lower concentrations of arsenic, cadmium, copper, lead, and zinc in the uppermost sample interval that generally contains high concentrations of these metals (Klein, Thamke, and others, 2003). Below the reduced mill tailings in sample 3-250, concentrations of all metals were substantially lower in the deep fluvial deposits, and there was no apparent postdepositional mobility of any metals, such as cadmium, copper, manganese, or zinc, as was observed in core $1-150$ (fig. 6).

The contrasting behavior of cadmium, copper, and zinc at these two sites was probably due to the difference in oxidation-reduction characteristics as seen in the upper parts of the two cores. As shown by core 1-150, downward percolating or laterally flowing surface water is thought to have substantially oxidized the tailings during weathering and to have mobilized cadmium, copper, and zinc.

The solubility of the geochemically mobile metals (cadmium, copper, and zinc) is highest under oxidizing conditions, which promote their migration into underlying material. These effects of weathering are enhanced by the porous nature of the underlying material, which allows rapid percolation of surface water through the mill tailings, and by the position of the mill tailings well above the local ground water. As shown by core 3-250, the upper parts of the deposits are mostly oxidized, fluvially transported, mixed mill tailings and mine waste. These materials probably had the same source as the deposits crossed by line 1 (fig. 3), as suggested by the abundance of coarse quartz chips. These quartz chips are mixed with a small amount of silty, reduced mill tailings that probably were locally derived. The similarity of profiles of the three mobile metals (cadmium, copper, and zinc) to those of the relatively immobile metals (arsenic and lead) suggests little postdepositional migration. The conditions in this area differ substantially from those at site $1-150$. Shallow ground water in this area produces near-surface reducing conditions that do not promote the solubility of cadmium, copper, or zinc. Lowpermeability material underlying clay-rich pond fill and the organic-rich pond fill deposits also may form a physical and chemical barrier to metal migration.

\section{Area A-Upper Frohner Meadows}

Mill tailings are concentrated in two areas in upper Frohner Meadows: a debris fan of fluvial material and mill tailings where Frohner Meadows creek enters the meadow (area A, fig. 3) and a large impoundment behind a sinuous beaver dam in area B, directly east of the Nellie Grant mine area.

The debris fan and the part of the meadow that lies east of the fan were sampled along a longitudinal core line at intervals of 40-100 ft (fig. 8). Sites and samples along this line are designated with the prefix " 1 ." Along the line 12 sites were cored; 8 cores were chosen for chemical analysis (fig. 8), and from those 8 cores, 31 intervals were sampled. Descriptions of the core samples and their geochemistry are contained in Klein, Thamke, and others (2003). A typical cross section is exposed in the bank of Frohner Meadows creek where it has cut through the western part of the debris fan (fig. 10). Mill tailings and associated coarse-grained quartz fragments overlie a thin layer of clay-rich, fine-grained mill tailings, which in turn overlie a sequence of fine- to medium-grained stream deposits and thin organic-rich clay layers that probably were formed in shallow ponds or wetlands. Klein, Thamke, and others (2003) reported total-digestion chemical analyses of sampled intervals in table 7 of that report. 


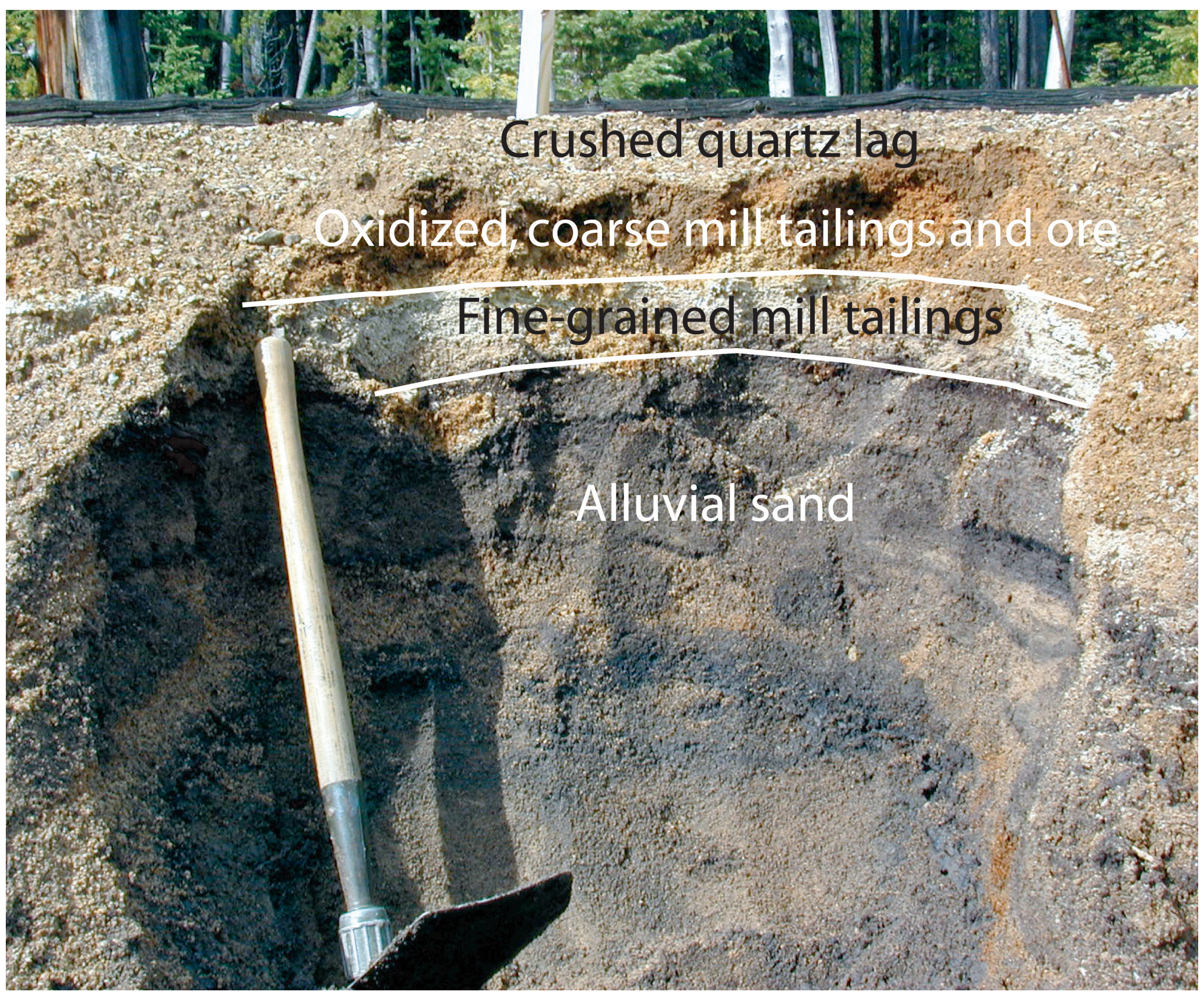

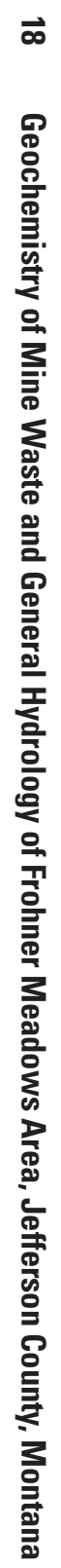

Figure 10. Trench showing cross section of mill-tailings debris fan along Frohner Meadows creek (fig. 3, area A, upper Frohner Meadows). Stratigraphic units are labeled. 
On the basis of those chemical analyses, core samples that exceeded the geochemical threshold (table 2) for any of the five metals are referred to in the following sections as "enriched" material. The mean minimum thickness of enriched material in the sampled cores taken along line 1 was $64 \mathrm{~cm}$; the greatest thickness was at site 1-150, where enriched material was greater than $111 \mathrm{~cm}$ thick (fig. 8). The thickness of enriched material was greater than that of actual mill tailings at many sites. Adjacent deposits that are not tailings likely were enriched as infiltrating surface water redistributed metals from the mill tailings during weathering. Thin soils (less than $8 \mathrm{~cm}$ thick) typically overlay these deposits. The stratigraphy of the cored material changes between sites 1-250 and 1-300, where fine-grained mill tailings were deposited directly over clay-rich pond deposits rather than over alluvium; similar relations were observed in all cores taken east of that site. In several cores, several sequences of pond deposits were interlayered with medium- to coarsegrained alluvium. Enriched material at site 1-600 was $35 \mathrm{~cm}$ thick; no coarse-grained mill tailings were observed at sites $1-600$ or $1-700$.

Core line 2 is located $300 \mathrm{ft}$ downstream from line 1 (fig. 3). Three sites were cored perpendicular to the long axis of the meadow, and nine intervals were sampled. Enriched intervals at sites 2-0 and 2-60 (fig. 8) were 55 and $78 \mathrm{~cm}$ thick, respectively, but the enriched layer thinned between site 2-60 and 2-130 to only $9 \mathrm{~cm}$. Enrichment at site 2-130 was marginal; zinc concentration was $380 \mathrm{ppm}$, only slightly higher than the enrichment threshold value of $340 \mathrm{ppm}$. Enriched intervals in this area directly overlay pond deposits at all sites. Soils were from 8 to $17 \mathrm{~cm}$ thick along this core line.

Because concentrations of ore-derived metals were highly variable within individual cores, the geochemical data in each core were vertically integrated by calculating a weighted average based on the thickness of the analyzed intervals. This weighted average allows comparison of the bulk compositions of enriched material among sites. Each sample was assumed to represent the composition of the entire stratigraphic unit in which it was found. The weighted-average concentration used to integrate the metal concentrations was calculated from the following equation:

\section{Weighted-average concentration $=$ $\sum$ (thickness of sampled interval $\times$ metal concentration of interval) / \\ $\sum$ thickness of sampled intervals}

The weighted-average concentration calculated for the ore-derived metals from cores in area A (fig. 3) is shown in figure 11. In the following discussion, sampled intervals were considered slightly enriched if they contained 1-5 times the premining background concentration of each metal, moderately enriched if they contained $>5$ and $\leq 10$ times the premining background concentration for each metal, and highly enriched if they contained $>10$ times the premining background value of each metal.
All cores in line 1, from 1-0 to 1-500 inclusive, and core 2-0 showed high weighted-average concentrations of arsenic, cadmium, and lead. Weighted-average concentrations of zinc and copper were moderate. Samples from cores 1-600, 2-60 and 2-130 were only slightly enriched in most metals or contained concentrations near the premining background concentrations, although sample 2-60 was highly enriched in cadmium. The lower weighted-average concentrations for all metals from samples at sites 1-600 and 2-130 are probably due to dilution by material having lower metal concentrations from sources east and north of the meadow.

\section{Area B-Upper Frohner Meadows}

In upper Frohner Meadows directly east of the Nellie Grant mine, a large volume of mill tailings is exposed (area B, fig. 3). Samples were taken along two core lines in this area of mill tailings; line 3 is perpendicular to the length of the meadow, and line 250 is located along a line with a bearing of N. $12^{\circ}$ E. from sample site 250 on line 3, roughly parallel to the length of the meadow (fig. 9). Along line 3, six sites were sampled at 50-100 ft intervals, and two samples were taken along line 250, at $75 \mathrm{ft}$ and $200 \mathrm{ft}$ north of line 3 . An additional sample site (UFM 1) lies southeast of site 3-0 near the toe of a debris fan at the outlet of Nellie Grant creek. The thickness of enriched material ranged from 33 to $88 \mathrm{~cm}$; the mean was $62 \mathrm{~cm}$. Mill tailings exposed in a shallow incised channel in the center of the meadow contain interlayered oxidized silt and fine sand-size mill tailings and coarse quartz chips (fig. 12), similar to the material observed along line 1 (fig. 10). The character of the surface mill tailings changes from the middle of this area, where coarse-grained and finegrained tailings interfinger, to the margins of the meadow, where tailings are fine- and medium-grained well-sorted sand. Samples from sites 3-0, 3-100, and 3-300 (fig. 9) contained the greatest thickness of the metal-enriched material. Mill tailings at sites 3-100 and 3-200 were mostly silt and clay, whereas at sites UFM 1, 3-250, 3-300, 250-75, and 250-200 sand-size mill tailings of various thicknesses overlay silt or clay tailings or mixed fine-grained mill tailings and pond sediment. Samples from site 3-390 did not contain identifiable mill tailings. Pond-fill sediment overlay the Mazama ash and coarse-grained alluvium at sites 3-200, 3-300, and 250-200.

The depositional history of the mill tailings here is complex. Frohner Meadows creek transported mill tailings from area A (fig. 3) to the main mill tailings deposits in area B and then deposited them in a natural pond behind a beaver dam. On the basis of features observed in cores UFM 1 and 3-0, we conclude that a second source of mill tailings probably was fine-grained mill tailings from the Nellie Grant mill that were released into Nellie Grant creek and entered the pond to form a delta. These fine-grained tailings also dispersed into the center of the meadow. Later, coarse-grained mill tailings, probably also from the Nellie Grant mill, were released and covered the earlier fine-grained mill tailings; later yet they were partially removed by erosion and dispersed into the center of the meadow. 

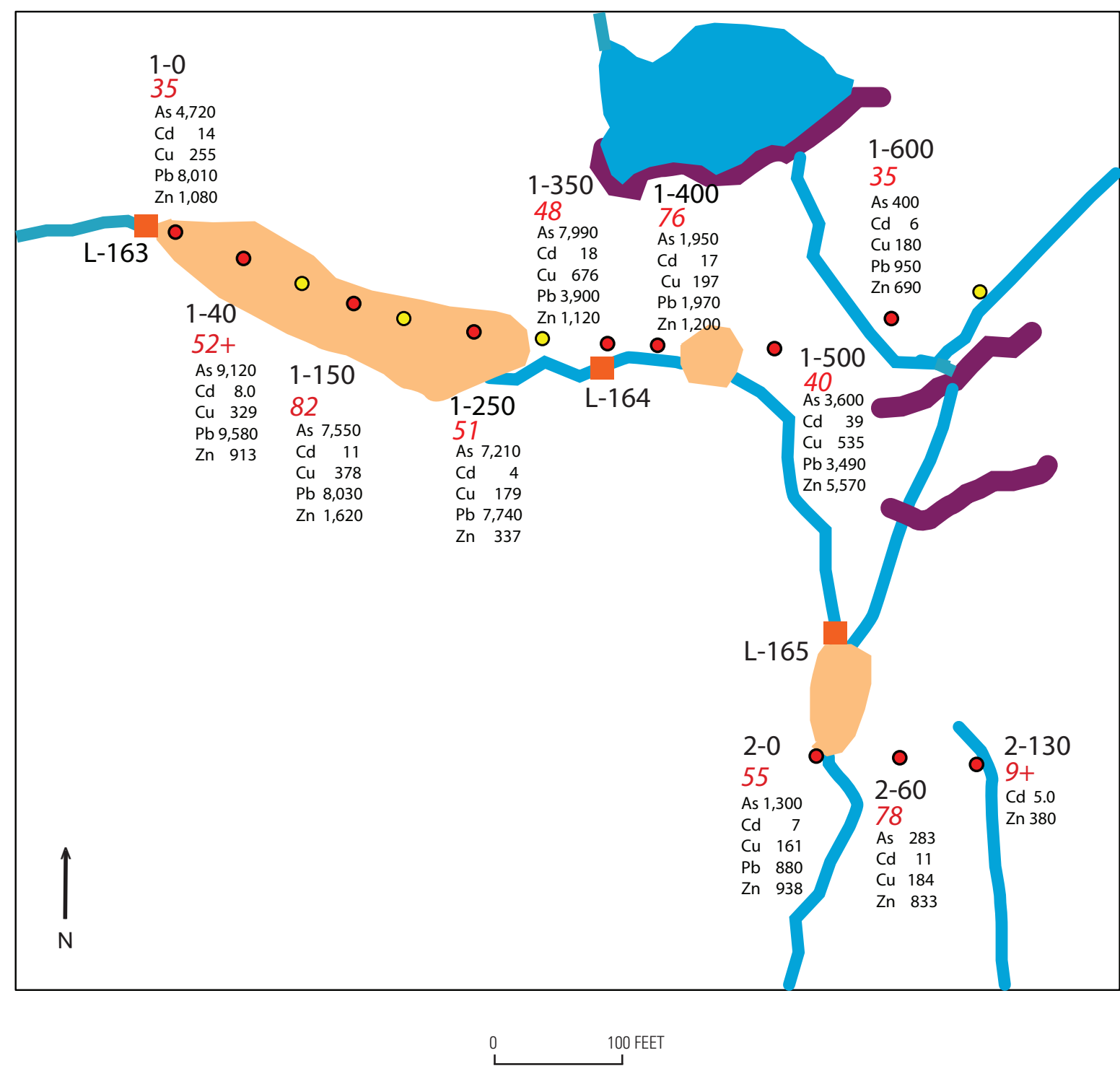

\section{EXPLANATION}

\begin{tabular}{|c|c|}
\hline & Minimum extent of exposed mill tailings \\
\hline & Pond \\
\hline & Stream \\
\hline & Dam \\
\hline 0 & Sampled core site-Site number in black, thickness of \\
\hline $2-130$ & sampled enriched material in red, and weighted average \\
\hline $9+$ & of metal concentrations for enriched interval (depth and \\
\hline Cd 5.0 & + , bottom of enriched interval not encountered \\
\hline $\begin{array}{l}\mathrm{Zn} 380 \\
0\end{array}$ & Core site (not sampled) \\
\hline & Stre \\
\hline
\end{tabular}

Figure 11. Upper mill-tailings area (fig. 3, area A, upper Frohner Meadows) showing thickness of enriched material and thickness-weighted averages of metal concentrations in enriched interval. 


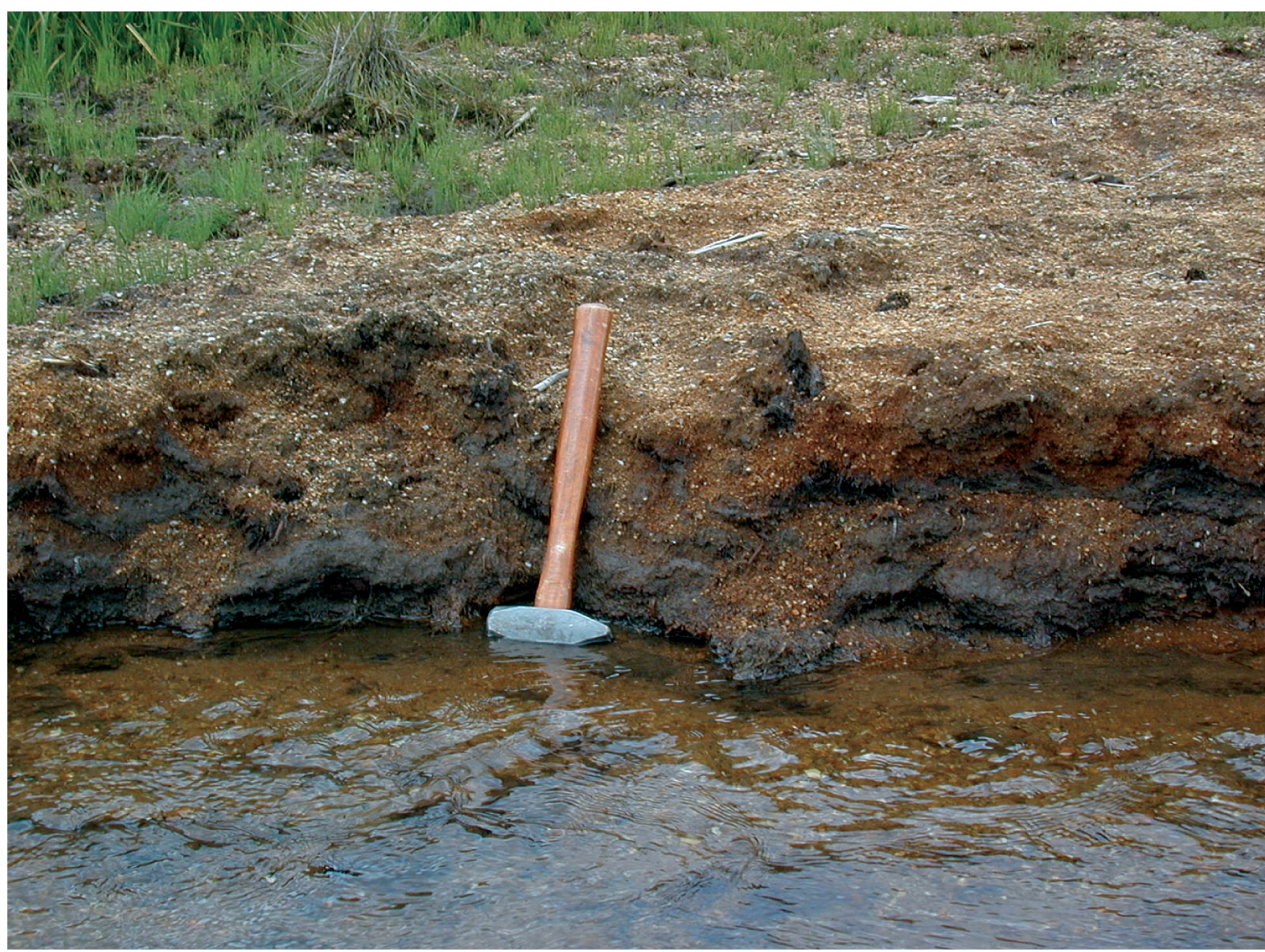

Figure 12. Mill tailings exposed along Frohner Meadows creek in main mill-tailings impoundment (fig. 3, area B, upper Frohner Meadows). Coarse quartz chips form a lag deposit overlying fine-grained oxidized mill tailings.

Two sites (4-0 and 4-100) that lie immediately below the main mill tailings impoundment (fig. 9) were sampled to determine the extent to which mill tailings had been transported downstream into the meadow and pond system. At site 4-0, an 11-cm-thick clay- and vegetation-rich layer overlay clay-rich pond deposits. These 14-cm-thick deposits were a mixture of silt- and clay-sized pond-fill deposits and transported clay or silt-size mill tailings. Fine-grained alluvial sand, older pond deposits, and Mazama ash underlie these pond-fill deposits and transported mill tailings. Enriched material, found only at site $4-0$, is greater than $62 \mathrm{~cm}$ thick. The stratigraphy at site $4-100$ is similar to that at site $4-0$ except that Mazama ash is not present.

The weighted-average concentrations of metals calculated for cores from area B are shown in figure 13. Mill tailings and underlying fine-grained, pond-fill deposits in all cores from sites 3-0 to 3-300 inclusive and from sites 250-75 and 250200 were highly enriched in cadmium. All sites were highly enriched in zinc, but zinc was highly variable; overall the weighted-average concentrations are about twice those of area A (fig. 11). Core material was variably enriched in arsenic and lead; arsenic and lead concentrations were much higher than geochemical threshold metal concentrations. Compared with the enrichment of material in cores from area A, material from cores in area B was enriched at most only by half and in some cores not at all (that is, it contained only background concentrations). The weighted-average concentrations of copper were higher than those concentrations in cores from area A but were only slightly above threshold concentrations. Weighted-average concentrations of all metals (except cadmium) in the silt- and clay-rich deposits in core 4-0 were lower than concentrations in samples from the mill tailings impoundment immediately upstream. Near-surface samples from core 4-100 were not chemically analyzed; the fine-grained sand that underlies the upper pond sequence showed no significant enrichment in any metal. The weighted-average concentrations of cadmium and zinc in UFM 1 were similar to those in other cores in area B. However, the weighted-average concentrations of arsenic and lead were much lower. This core sampled an artesian outflow zone. The artesian water is derived from Nellie Grant creek, and a metal-contaminated ground-water plume may have more greatly enriched the tailings sediments in zinc and cadmium than in lead and arsenic. This interpretation is supported by the high concentrations of zinc and cadmium that are found in surface water in Nellie Grant creek and in ground water in monitoring well MW-1 (fig. 14, table 3). 


\section{Area C-Lower Frohner Meadows}

Lower Frohner Meadows (area C, fig. 3) contains several water-filled abandoned beaver ponds and many dry ponds with breached dams (fig. 15). In most of the breached beaver ponds, streams are eroding the highly organic and clay-rich pond-fill deposits and incising stream channels. The ponds (both wet and dry) are separated by relatively dry meadowlands in the upper part of the meadow system and by wetlands in the lower part, near the meadow outlet. The most recent mining activity at the Nellie Grant mine created a small delta of mill tailings in the southwest corner of the uppermost pond (which is water filled) (Jack Yates, Montana Department of Environmental Quality, oral commun., 2001).

The minimum extent of the mill-tailings delta, as judged visually, is shown in figure 15 . The delta was characterized by one $125-\mathrm{cm}$ core at site LFMC 1 . Enriched mill tailings of finesand-size material grades downward into clay-rich pond deposits; the tailings are approximately $40 \mathrm{~cm}$ thick. Fine-grained pyrite is abundant, and partially oxidized pyrite is present to about $30 \mathrm{~cm}$ depth. The mill tailings are water saturated and form a marshy area near the high-water level of the pond.

Core line 5 is about $300 \mathrm{ft}$ downstream from the milltailings delta in a relatively flat dry meadow. Five cores, ranging in depth from 73 to $137 \mathrm{~cm}$, were taken at $100 \mathrm{ft}$ intervals along line 5. Pond-fill deposits 35 to $96 \mathrm{~cm}$ thick overlie Mazama ash, periglacial fluvial deposits, or moraine deposits in all cores.

Along core line 6, fine-grained pond-fill deposits in a breached beaver pond were sampled. The pond-fill deposits range from 19 to $61 \mathrm{~cm}$ thick and consist of fine-grained, highly organic clay and silt containing abundant woody debris. These deposits overlay medium- to fine-grained alluvial deposits and periglacial fluvial sediment.

Cores LFMC 1 and 6-0 contained the highest weightedaverage concentrations of metal in area C (fig. 16). Samples of mill tailings in LFMC 1, which probably derive from the Nellie Grant mine, contained weighted-average concentrations of metal similar to those in core 3-0 in area B (fig. 13). The enriched material consists of fine-grained mill tailings; some underlying clay-rich pond-fill deposits were highly enriched in cadmium and zinc and much less enriched in arsenic and lead, as is true also in Nellie Grant mine waste and mill tailings. Arsenic, cadmium, and zinc concentrations in core $6-0$ were similar to those concentrations in LFMC 1 , but core 6-0 had a much higher weighted-average concentration of lead. The source of this lead may be clastic grains of lead-rich minerals in mill tailings in upper Frohner Meadows, which typically contain abundant lead, transported by Frohner Meadows creek to lower Frohner Meadows, where mill tailings typically contain less lead. The most enriched material in the upper part of fine-grained pond-fill deposits in core 6-0 consisted of organic material only; fine-grained alluvium in the lower part (below $31 \mathrm{~cm}$ ) was not analyzed.

Sites 5-200 and 5-300 show moderate concentrations of ore-related metals in fine-grained pond-fill; the greatest thickness of enriched material is at site 5-300. The horizontal and vertical extent of contaminated material along line 5 was not adequately defined by sampling. Samples from sites $5-0$ and 5-400 were not analyzed, and at site 5-100, only alluvium lying below pond-fill deposits (below $113 \mathrm{~cm}$ ) was analyzed; its metal content was below threshold concentrations (table 2).

As was shown in all core samples from lower Frohner Meadows, only the fine-grained upper part of the pond-fill deposits was enriched in metals. In some cases, the lower part of the fine-grained pond-fill deposits was uncontaminated. In all cases, the coarser grained alluvium underlying the finegrained pond deposits was uncontaminated, and this characteristic suggests that deposition of metal from ground water is not an important factor in metal accumulation in this area. Older buried alluvium was not enriched to a significant degree in ore-related metals.

\section{Upper Lump Gulch}

Frohner Meadows creek discharges into upper Lump Gulch in the southeastern part of the study area. A small meadow has formed in a sediment-filled reservoir in upper Lump Gulch about $700 \mathrm{ft}$ below the outlet of Frohner Meadows creek (fig. 3). A water-diversion structure here is the source of water for Park Lake, which lies about $1 \mathrm{mi}$ to the northeast. Stream bed-sediment and water samples taken in 2000 during a watershed-characterization study identified material enriched in ore-related metals at the outlet of Frohner Meadows creek (Klein and others, 2001). Metal concentrations decline substantially through the stream reach below this reservoir in upper Lump Gulch.

Three cores (LGFR 1, 2, and 3) that ranged from 132 to $190 \mathrm{~cm}$ in depth were taken to determine the mechanism that reduces metal concentrations in water and stream bed sediment below the outlet of Frohner Meadows creek. The upper $20 \mathrm{~cm}$ of core LGFR 1 was dark red silt that appeared to be oxidized and fine-grained transported mill tailings (Klein, Thamke, and others, 2003). The lower part of all cores was interbedded thick pond-fill deposits and fine-grained alluvium that was as much as $157 \mathrm{~cm}$ thick. In cores LGFR 1 and 3, which extended deeper than LGFR 2, interbedded pond fill and fine-grained alluvium overlay very coarse, poorly sorted alluvium that probably was periglacial.

Because these cores were enriched only slightly in ore-related metals, and enriched material is vertically discontinuous, weighted-average concentrations of metals were not calculated. In LGFR 1, the upper $20 \mathrm{~cm}$, which we interpreted to be fine-grained fluvial mill tailings, was highly enriched in cadmium and zinc and moderately enriched in arsenic and lead relative to the respective threshold concentrations of those metals. Near the bottom of this core, between 91 and $152 \mathrm{~cm}$, medium- and coarse-grained alluvium that contained abundant grains coated with manganese oxyhydroxide was slightly enriched in cadmium and zinc. This interval was slightly enriched in arsenic; it contained about twice the premining threshold concentration. Clay-rich, highly organic pond-fill deposits enclosed this coarse-grained alluvium. 

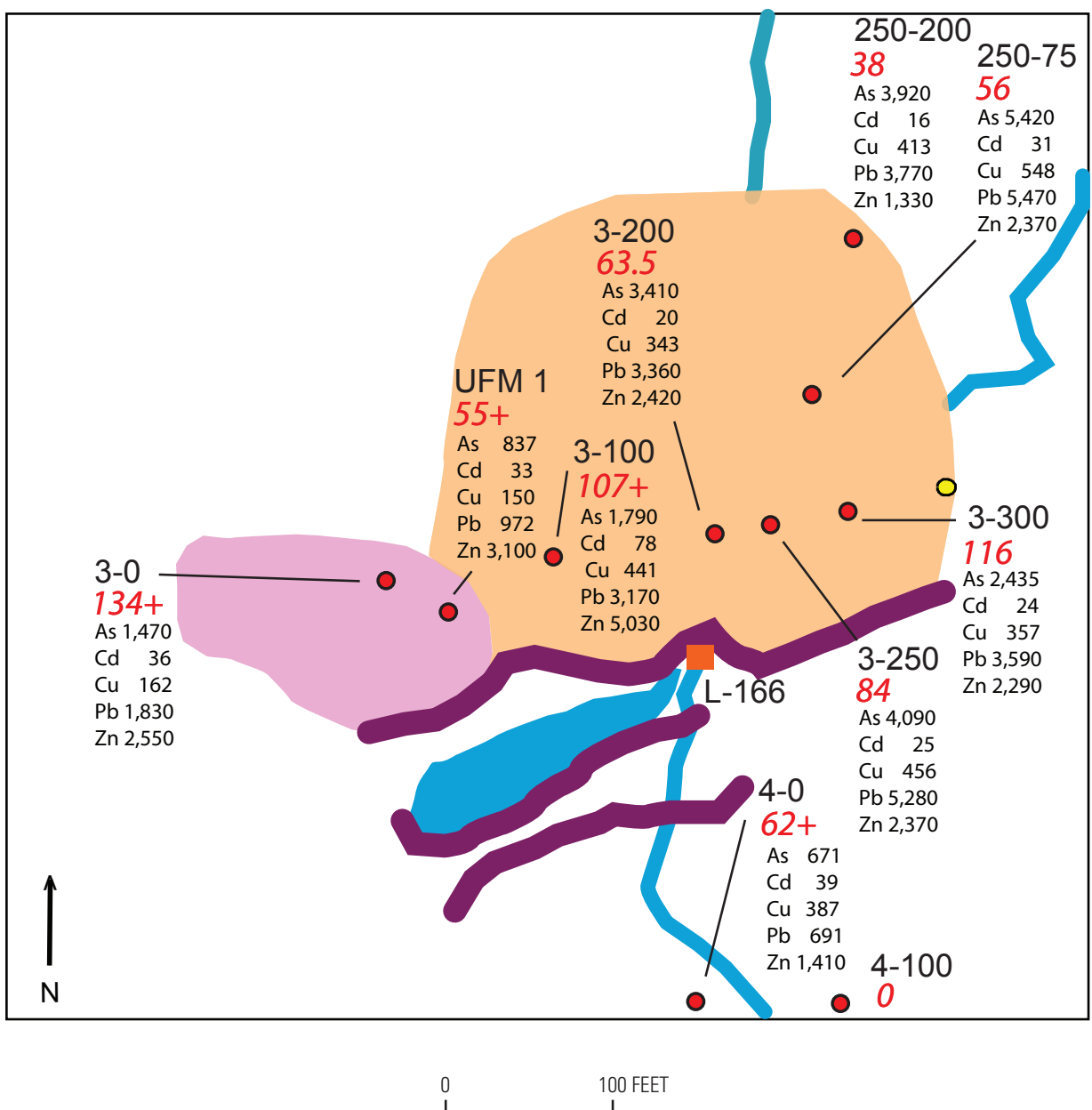

\section{EXPLANATION}

\begin{tabular}{|c|c|}
\hline & $\begin{array}{l}\text { Minimum extent of exposed mill tailings } \\
\text { Approximate extent of Nellie Grant tailings debris fan }\end{array}$ \\
\hline & $\begin{array}{l}\text { Pond } \\
\text { Stream }\end{array}$ \\
\hline & Dam \\
\hline 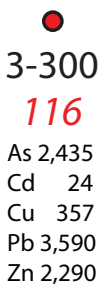 & $\begin{array}{l}\text { Sampled core site-Site number in black, thickness of } \\
\text { sampled enriched material in red, and weighted } \\
\text { average of metal concentrations for enriched interval } \\
\text { (depth and thickness in centimeters, concentration in } \\
\text { parts per million); +, bottom of enriched interval not } \\
\text { encountered }\end{array}$ \\
\hline 0 & Core site (not sampled) \\
\hline & Stream bed sediment sample site \\
\hline
\end{tabular}

Figure 13. Main mill tailings area (fig. 3, area B, upper Frohner Meadows) showing thickness of enriched material and thickness-weighted averages of metal concentrations in enriched interval. 


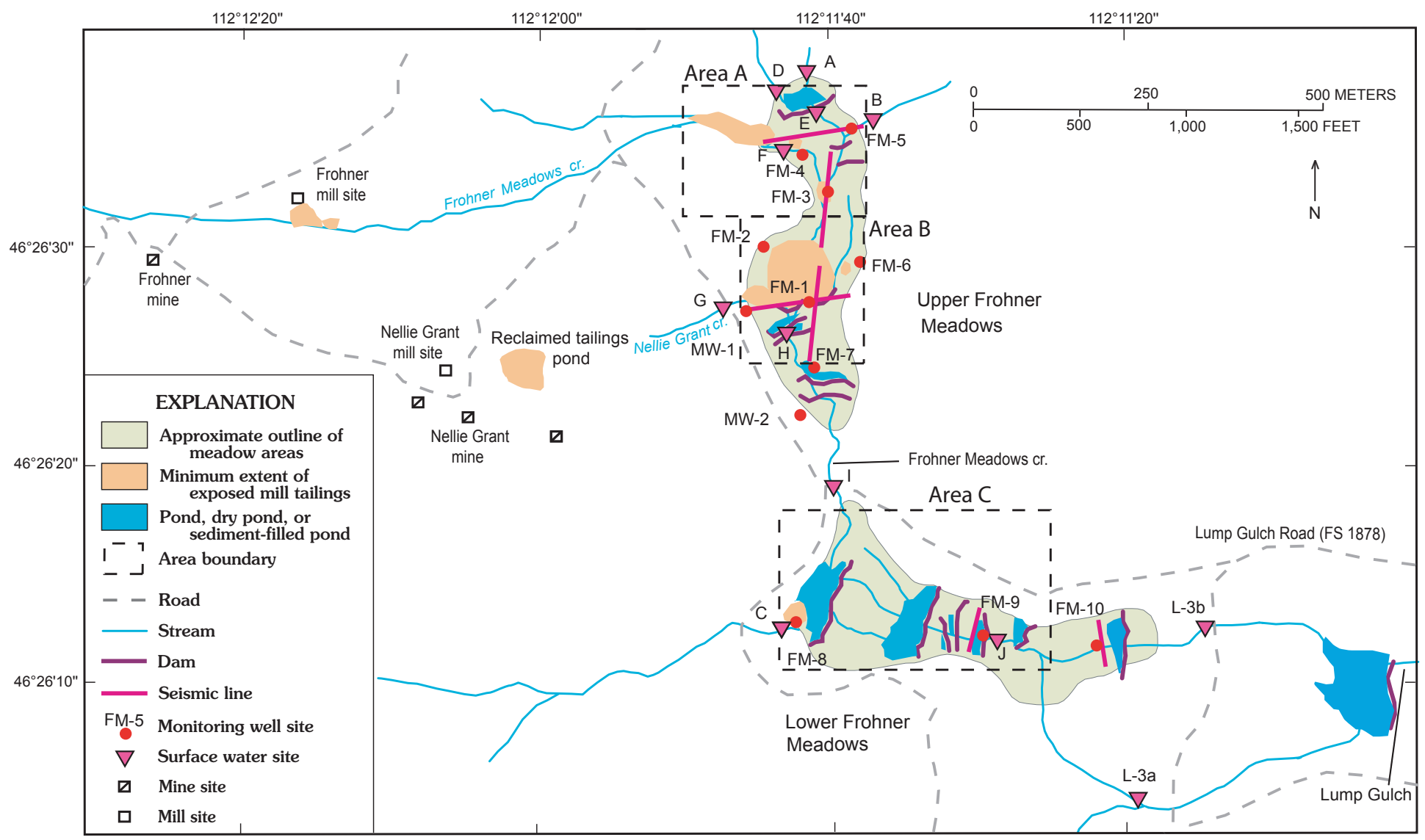

Figure 14. Location of monitoring wells, seismic lines, and surface-water sampling sites in and near Frohner Meadows. 
Table 3. Concentrations and instantaneous loads of total recoverable trace metals in Frohner Meadows area.

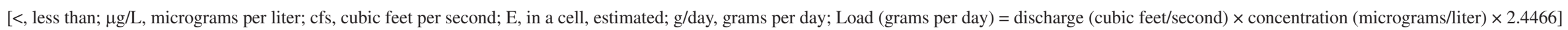

\begin{tabular}{|c|c|c|c|c|c|c|c|c|c|c|c|c|c|c|}
\hline \multirow[b]{2}{*}{ Site ID } & \multirow[b]{2}{*}{$\begin{array}{c}\text { Site } \\
\text { name }\end{array}$} & \multirow[b]{2}{*}{ Date } & \multirow[b]{2}{*}{ Time } & \multirow{2}{*}{$\begin{array}{l}\text { Instantaneous } \\
\text { discharge } \\
\text { (cfs) }\end{array}$} & \multicolumn{2}{|c|}{ Arsenic } & \multicolumn{2}{|c|}{ Cadmium } & \multicolumn{2}{|c|}{ Copper } & \multicolumn{2}{|c|}{ Lead } & \multicolumn{2}{|c|}{ Zinc } \\
\hline & & & & & $\begin{array}{c}\text { Total } \\
\text { recoverable } \\
(\mu \mathrm{g} / \mathrm{L})\end{array}$ & $\underset{\text { (g/day) }}{\text { Load }}$ & $\begin{array}{c}\text { Total } \\
\text { recoverable } \\
(\mu \mathrm{g} / \mathrm{L})\end{array}$ & $\begin{array}{c}\text { Load } \\
\text { (g/day) }\end{array}$ & $\begin{array}{c}\text { Total } \\
\text { recoverable } \\
(\mu \mathrm{g} / \mathrm{L})\end{array}$ & $\begin{array}{l}\text { Load } \\
\text { (g/day) }\end{array}$ & $\begin{array}{c}\text { Total } \\
\text { recoverable } \\
(\mu \mathrm{g} / \mathrm{L})\end{array}$ & $e_{(\text {g/day) }}^{\text {Load }}$ & $\begin{array}{c}\text { Total } \\
\text { recoverable } \\
(\mu \mathrm{g} / \mathrm{L})\end{array}$ & $\begin{array}{l}\text { Load } \\
\text { (g/day) }\end{array}$ \\
\hline \multirow[t]{2}{*}{462638112114201} & A & $6 / 25 / 2001$ & 1255 & 0.0353 & E1 & E0.09 & E0.03 & E0.002 & 3.2 & 0.28 & $<1$ & $<0.09$ & 4 & 0.35 \\
\hline & & $8 / 1 / 2001$ & 945 & 0.00353 & 2 & 0.02 & E0.03 & E0.0002 & 2.2 & 0.02 & $<1$ & $<0.009$ & 5 & 0.04 \\
\hline 462636112113801 & B & $6 / 25 / 2001$ & 1340 & 0.00353 & $<2$ & $<0.02$ & 0.07 & 0.001 & 3.0 & 0.03 & $<1$ & $<0.009$ & 3 & 0.03 \\
\hline \multirow[t]{2}{*}{462637112114401} & $\mathrm{D}$ & $6 / 26 / 2001$ & 910 & 0.0162 & 3 & 0.12 & 0.05 & 0.002 & 4.1 & 0.16 & 2 & 0.079 & 7 & 0.28 \\
\hline & & $8 / 1 / 2001$ & 1020 & 0.027 & 9 & 0.59 & 0.07 & 0.005 & 3.3 & 0.22 & 3 & 0.198 & 11 & 0.73 \\
\hline \multirow[t]{2}{*}{462637112114101} & $\mathrm{E}$ & $6 / 26 / 2001$ & 945 & 0.2066 & 16 & 8.09 & 0.12 & 0.061 & 5.1 & 2.58 & 4 & 2.02 & 20 & 10.1 \\
\hline & & $8 / 1 / 2001$ & 1050 & 0.0247 & 55 & 3.32 & 0.13 & 0.008 & 5.0 & 0.30 & 12 & 0.725 & 21 & 1.27 \\
\hline \multirow[t]{2}{*}{462635112114401} & $\mathrm{~F}$ & $6 / 26 / 2001$ & 1005 & 0.6048 & 17 & 25.2 & 1.40 & 2.07 & 7.3 & 10.8 & 9 & 13.3 & 284 & 420 \\
\hline & & $8 / 1 / 2001$ & 1135 & 0.138 & 25 & 8.44 & 2.49 & 0.84 & 8.0 & 2.70 & 11 & 3.71 & 505 & 171 \\
\hline \multirow[t]{2}{*}{462627112114701} & G & $6 / 26 / 2001$ & 1040 & 0.063 & 208 & 32.1 & 121 & 18.7 & 83.9 & 12.9 & 72 & 11.1 & 15,100 & 2,330 \\
\hline & & $8 / 1 / 2001$ & 1240 & 0.006 & 45 & 0.66 & 94.0 & 1.38 & 15.9 & 0.23 & 13 & 0.191 & 13,400 & 197 \\
\hline \multirow[t]{3}{*}{462626112114301} & $\mathrm{H}$ & $6 / 26 / 2001$ & 1115 & 0.76 & 39 & 72.5 & 7.16 & 13.3 & 8.0 & 14.9 & 10 & 18.6 & 1,110 & 2,060 \\
\hline & & $8 / 1 / 2001$ & 1205 & 0.203 & 81 & 40.2 & 6.23 & 3.09 & 8.0 & 3.97 & 15 & 7.45 & 1,130 & 561 \\
\hline & & $10 / 16 / 2001$ & 1105 & 0.09 & 52 & 11.5 & 7.92 & 1.74 & 6.4 & 1.41 & 9 & 1.98 & 1,920 & 423 \\
\hline \multirow[t]{3}{*}{462619112114001} & I & $6 / 26 / 2001$ & 1200 & 0.86 & 38 & 80.0 & 6.94 & 14.6 & 8.9 & 18.7 & 8 & 16.8 & 1,180 & 2,480 \\
\hline & & $8 / 1 / 2001$ & 1350 & 0.212 & 71 & 36.8 & 6.00 & 3.11 & 7.7 & 3.99 & 13 & 6.74 & 1,120 & 581 \\
\hline & & $10 / 16 / 2001$ & 1140 & 0.15 & 23 & 8.44 & 8.96 & 3.29 & 5.4 & 1.98 & 4 & 1.47 & 2,320 & 851 \\
\hline \multirow[t]{2}{*}{462613112114401} & $\mathrm{C}$ & $6 / 25 / 2001$ & 1540 & 0.0671 & E1 & E0.16 & E.03 & E0.005 & 3.0 & 0.49 & $<1$ & $<0.16$ & 2 & 0.33 \\
\hline & & $8 / 1 / 2001$ & 1420 & 0.01 & 4 & 0.10 & .06 & 0.001 & 2.8 & 0.07 & 3 & 0.073 & 6 & 0.15 \\
\hline \multirow[t]{2}{*}{462612112113001} & $\mathrm{~J}$ & $6 / 26 / 2001$ & 1300 & 0.91 & 34 & 75.7 & 6.89 & 15.3 & 8.4 & 18.7 & 10 & 22.3 & 1,110 & 2,470 \\
\hline & & $8 / 1 / 2001$ & 1500 & 0.311 & 64 & 48.7 & 5.66 & 4.31 & 7.6 & 5.78 & 42 & 32.0 & 1,020 & 776 \\
\hline \multirow[t]{4}{*}{462603112112101} & L-3a & $6 / 16 / 2000$ & 1415 & 0.62 & 6 & 9.10 & 6.31 & 9.57 & 7.4 & 11.2 & 2 & 3.03 & 1,450 & 2,200 \\
\hline & & $10 / 11 / 2000$ & 1345 & 0.0003 & 10 & 0.01 & 9.76 & 0.01 & 2.7 & $<0.001$ & $<1$ & $<0.001$ & 3,970 & 2.91 \\
\hline & & $5 / 10 / 2001$ & 1100 & 0.26 & 7 & 4.45 & 6.67 & 4.24 & 7.3 & 4.64 & 2 & 1.27 & 1,630 & 1,040 \\
\hline & & $8 / 1 / 2001$ & 1130 & 0.004 & 11 & 0.11 & 5.21 & 0.05 & 6.9 & 0.07 & 2 & 0.020 & 1,360 & 13.3 \\
\hline \multirow[t]{5}{*}{462612112111501} & L-3b & $6 / 16 / 2000$ & 1445 & 1.17 & 15 & 42.9 & 13.1 & 37.5 & 11.0 & 31.5 & 8 & 22.9 & 2,650 & 7,590 \\
\hline & & $10 / 11 / 2000$ & 1630 & 0.11 & 6 & 1.61 & 47.1 & 12.7 & 5.8 & 1.56 & 4 & 1.08 & 15,400 & 4,150 \\
\hline & & $3 / 15 / 2001$ & 1130 & 0.06 & 17 & 2.50 & 15.6 & 2.29 & 10.3 & 1.51 & 9 & 1.32 & 4,720 & 693 \\
\hline & & $5 / 10 / 2001$ & 1120 & 0.78 & 14 & 26.7 & 13.1 & 25.0 & 11.4 & 21.8 & 7 & 13.4 & 2,510 & 4,790 \\
\hline & & $8 / 1 / 2001$ & 0950 & 0.233 & 33 & 18.8 & 4.99 & 2.84 & 6.5 & 3.71 & 8 & 4.56 & 1,190 & 678 \\
\hline
\end{tabular}



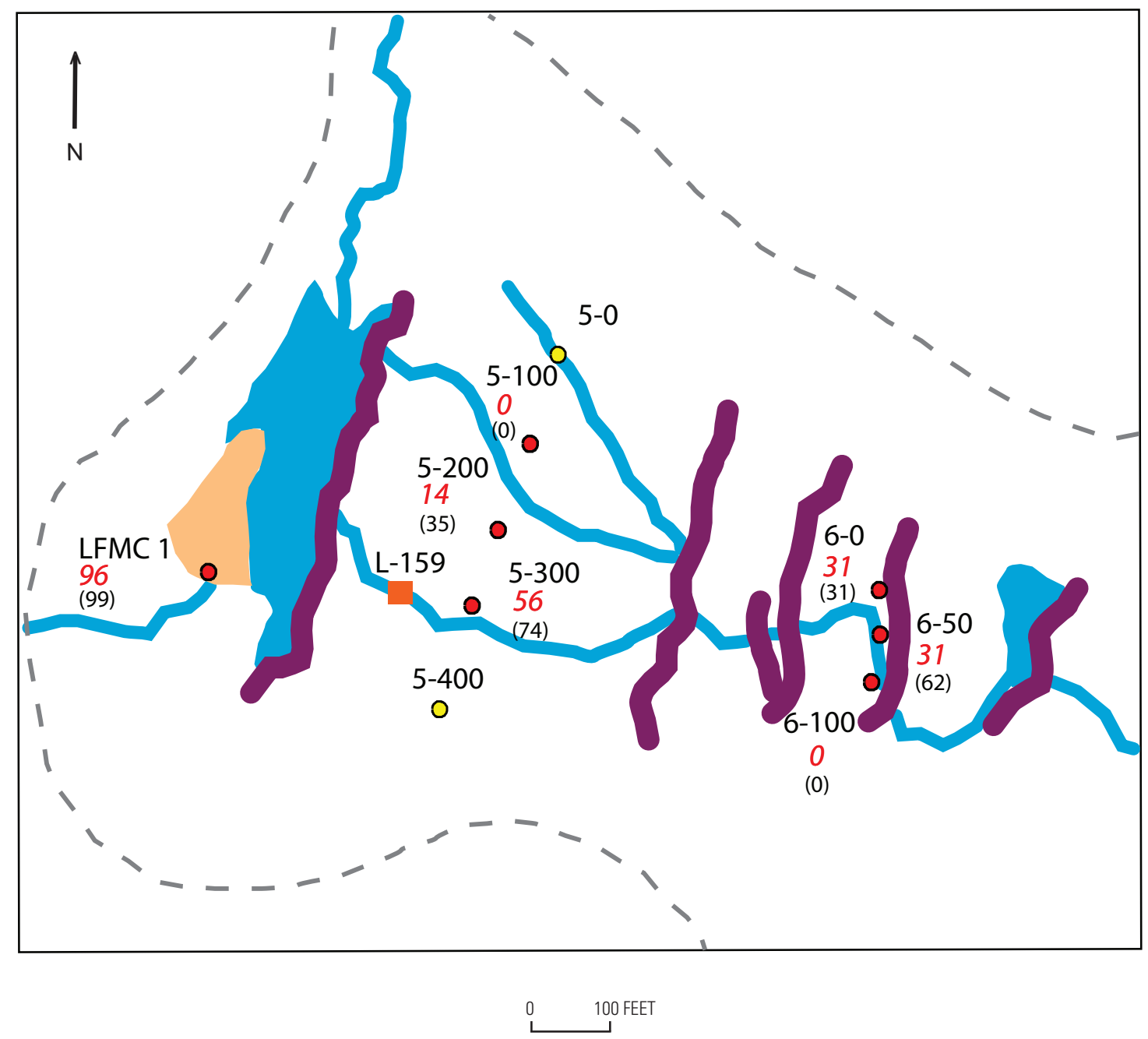

\section{EXPLANATION}

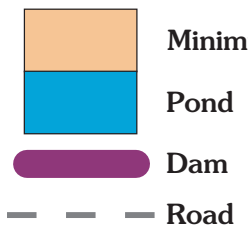

Road

- Sampled core site-Site number in black,

5-200 thickness of sampled enriched material

14 in red, and depth of bottom of enriched

(35) interval in parentheses (depth and

(35) thickness in centimeters).

○ Core site (not sampled)

Stream bed sediment sample site

Figure 15. Lower Frohner Meadows (fig. 3, area C) showing thickness of enriched material and depth to bottom of enriched interval. 

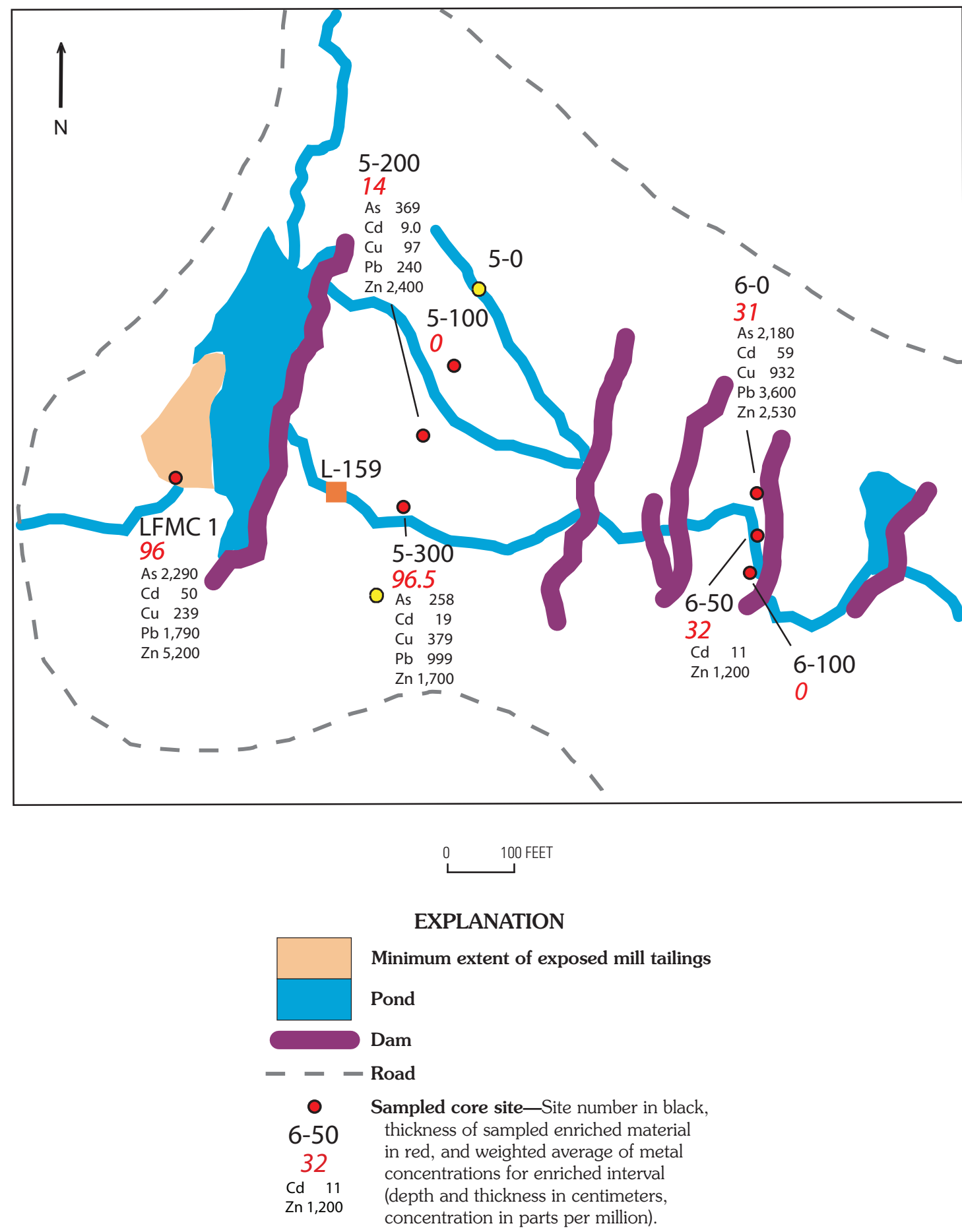

○ Core site (not sampled)

Stream bed sediment sample site

Figure 16. Lower Frohner Meadows (fig. 3, area C) showing thickness of enriched material and thicknessweighted averages of metal concentrations in enriched interval. 
Near the surface in core LGFR 2, medium-grained alluvium was slightly enriched in arsenic, cadmium, and zinc relative to the local geochemical threshold concentration (table 2). Near the bottom of the core, interbedded fine sand and clay that lay beneath clay-rich pond fill also were slightly enriched in cadmium and zinc. In the upper part of core LGFR 3 coarse-grained alluvium was slightly enriched in cadmium and zinc, whereas coarse-grained alluvium in the bottom 30 $\mathrm{cm}$ was slightly enriched in arsenic and lead.

In cores LGFR 1 and 2, buried, permeable, medium- and coarse-grained alluvium enriched in cadmium and zinc suggests that these metals may be accumulating in the subsurface from metal-enriched ground water. The two deepest samples taken from LGFR 1 and the deepest sample taken from LGFR 2 were below clay layers that may restrict ground-water flow into the underlying, more permeable, coarse-grained alluvial layers. The most likely source of metal is the highly contaminated surface water that leaves Frohner Meadows near site L-3b (fig. 3), immediately upstream from this reservoir site. The uppermost samples of these two cores were enriched in all ore-related metals, perhaps owing to transport of grains that contain arsenic and lead minerals and to solution transport of cadmium and zinc by the most recent alluvial material filling the reservoir. Coatings of iron and manganese oxyhydroxides on stream-transported sediments may themselves be enriched in zinc and cadmium and thus contribute zinc and cadmium to shallow deposits.

Site LGFR 3 lies along a tributary of the south fork of upper Lump Gulch Creek that drains Frohner Meadows through site $\mathrm{L}-150$. The near-surface parts of this core were slightly enriched in cadmium and zinc, probably because surface water that leaves Frohner Meadows upstream from $\mathrm{L}-150$ is enriched in cadmium and zinc. The two deepest samples in LGFR 3 were slightly enriched in arsenic and lead. Arsenic may be transported in ground water under reducing conditions, as is noted in some ground-water monitoring wells in upper Frohner Meadows, but lead (which has a very low solubility in water under all natural conditions) can be transported in significant concentrations only as clastic material. Therefore, this enriched material probably contains arsenic- and lead-bearing minerals transported early in the history of this reservoir, a time that predated the pondfilling sedimentation, which in turn predated construction of the impoundment and diversion structure.

\section{Panama Mine Meadows}

A large, abandoned, sediment-filled reservoir that lies about 1 mi southwest of lower Frohner Meadows was sampled to determine the origin of its fill material. The reservoir consists of a series of dry and water-filled beaver ponds and intervening meadows that have developed behind a breached diversion dam (fig. 3). Three cores (PMC 1, 2, and 3), ranging in depth from 58 to $80 \mathrm{~cm}$, showed that the deposits that fill the reservoir were interbedded pond-fill deposits and medium to coarse alluvial sand and gravel consisting largely of granite pebbles (Klein, Cannon, and Fey, 2003, appendix 1). These coarse clastic deposits are derived locally from the surrounding granitic rocks of the Boulder batholith.

In core PMC 3, one clay-rich pond-fill interval was slightly enriched in arsenic and lead relative to premining concentrations (Klein, Thamke, and others, 2003). The source of the metals and the extent of the enrichment are unknown. Background concentrations of metals in water and stream bed sediment at site L-1 (fig. 3) (Klein and others, 2001) suggest that the active stream system is not the source of this lead and arsenic. Samples from PMC 1 showed no unusual metal accumulations.

\section{Thickness-Weighted Average Concentrations of Ore-Related Metal in Core Samples}

For all enriched intervals in cores in each of the three areas (A, B, and $\mathrm{C}$ in fig. 3), thickness-weighted average concentrations of the five ore-related metals were calculated; the calculated concentrations allow comparison of bulk chemistry among areas containing enriched material. Materials present in different parts of the meadow system and that contain various bulk-metal concentrations (table 4) can be compared in terms of their potential for contributing metals to ground water, surface water, and stream bed sediment. These calculated concentrations also serve as an estimate of the metal's bulk concentration in contaminated material. This information may be useful during any remediation efforts.

Cores from area A contained the highest bulk concentrations of arsenic and lead, whereas cores from areas B and $\mathrm{C}$ were highest in cadmium and zinc. This relationship is similar to that observed in bulk surface samples of mine and mill tailings from the same areas. These average arsenic, lead, and cadmium concentrations in cores from areas A, B, and $\mathrm{C}$ greatly exceeded the geochemical threshold concentrations for each metal (table 2) and showed that sediment deposits in the cored areas were highly enriched in these metals. In upper Lump Gulch, enriched clastic material in cores from the filled reservoir contained weighted-average metal concentrations of arsenic, copper, and lead near or below their geochemical threshold concentrations, but concentrations of cadmium and zinc were about twice their threshold concentrations.

\section{Stream Bed Sediment}

Stream bed sediments were sampled to locate stream reaches that are enriched in metals owing to natural or human causes. Concentrations of chemical elements in stream bed sediment present a time-integrated view of chemical input from two sources: erosion of underlying bedrock and glacial debris upstream from the sample site and erosion of natural or cultural point sources such as outcrops of ore deposits or mines and mills (either active or abandoned). Downstream from natural outcrops of base- and precious-metal deposits 
Table 4. Weighted-average concentration of contaminated material in core samples, by area.

[All concentrations in parts per million]

\begin{tabular}{lcccrr}
\hline \multicolumn{1}{c}{ Location } & Arsenic & Cadmium & Copper & Lead & Zinc \\
\hline Area A-Upper Frohner Meadows & 3,520 & 12 & 268 & 3,520 & 1,190 \\
Area B-Upper Frohner Meadows & 1,980 & 36 & 293 & 2,650 & 2,860 \\
Area C-Lower Frohner Meadows & 277 & 11 & 189 & 595 & 863 \\
Lower Frohner Meadows mill tailings (LFMC 1) & 2,290 & 50 & 239 & 1,790 & 5,200 \\
Upper Lump Gulch filled reservoir & 109 & 9 & 66 & 156 & 648 \\
\hline
\end{tabular}

and below mine and mill sites, sediment deposits such as those in the Frohner Meadows area typically are enriched in ore-related trace metals (arsenic, cadmium, copper, lead, and zinc). Ore-related metals accumulate in stream bed sediment either as detrital grains of the original ore minerals or host rock or as secondary minerals formed during weathering of ore minerals. The bulk of the secondary minerals is composed of colloidal iron and manganese oxyhydroxides, which generally accumulate as coatings on sediment grains. These coatings are relatively unstable; they are easily eroded and transported during periods of increased stream discharge, are easily dissolved by a decrease in oxidation-potential of stream water, and may be leached from grain coatings by a decrease in the $\mathrm{pH}$ of stream water. Other physical variables, such as stream velocity, changes in stream gradient, and shallow ground-water contributions also can affect the amount of metal in stream bed sediment.

The biogeochemical effects of high metal concentrations in stream bed sediment on the ecosystem and surface-water chemistry are complex. In terms of the local ecosystem, metals in stream bed sediment promote the accumulation of metals in benthic fauna, which feed on and live in stream bed sediment (MacDonald and others, 2000). Benthic fauna in turn is a major food source for many freshwater fish, and metals accumulated in benthic fauna may be transferred to fish (Farag and others, 2004). The effects on water chemistry of metals in stream bed sediment are more complex. The silicate and oxide mineral grains that make up most of the stream bed sediment are relatively resistant to weathering and release only small amounts of metals during a long period of weathering (Church and others, 1993). Thus, high concentrations of metals in silicate and oxide grains likely have little effect on water chemistry. However, metals found in iron and manganese oxyhydroxide grain coatings can markedly affect water chemistry, because relatively large releases of metals into water may be induced by relatively small changes in water chemistry, such as oxidation potential and $\mathrm{pH}$, or flow conditions during a short time period (Horowitz, 1991).

\section{Regional Background-Metal Concentrations in Stream Bed Sediment}

Regional background-metal concentrations in stream bed sediment were determined for the upper Prickly Pear Creek watershed (fig. 1 of this report) (Klein and others, 2001). Background concentrations of arsenic, cadmium, copper, lead, and zinc were determined on samples from sites in streams that drain areas having little or no mining history and that are underlain by unmineralized granitic bedrock typical of much of the watershed. The measured background concentrations (determined by total digestion) are much higher than their respective mean crustal abundances in granitic rocks. These elevated background concentrations may, in part, result from the same regional hydrothermal alteration that produced many base- and precious-metal deposits in the heavily mineralized northern part of the Boulder batholith. These regionalbackground concentrations in the upper Prickly Pear Creek watershed were used to evaluate the degree to which stream bed-sediment samples from Frohner Meadows are enriched in ore-related metals.

\section{Stream Bed-Sediment Consensus-Based Probable-Effect Concentrations}

The health of aquatic organisms is one measure of the biological effect of metal contamination in a stream reach. The minimum concentrations at which various metals in stream bed sediment harm the health of aquatic organisms have not been firmly established. Because the mechanisms of metal uptake and the effects of metals on an organism's health are poorly understood, no standard has yet been adopted by any major environmental agency. Currently, the best alternative to such standards is called the "consensus-based probable-effect concentration" (CBPEC). These values are based on the protective concentrations of metals as determined by a consensus among several methods (MacDonald and others, 2000). A CBPEC identifies the contaminant concentration above which sediment-dwelling organisms commonly are harmed. CBPEC values were derived from the geometric-mean concentration of selected published effects-based sediment-quality guidelines. The total analysis method of sediment analysis was used to establish the CBPEC. These concentrations then were evaluated for reliability by pairing sediment chemistry data with toxicity data. The CBPEC values (MacDonald and others, 2000) are used in this report to relate metal concentrations in the stream bed sediment in Frohner Meadows to concentrations of metals that may produce toxic effects on aquatic organisms. 


\section{Metal Concentrations in Frohner Meadows Compared with Background Concentrations and CBPEC Standards}

Stream bed sediment from Frohner Meadows and from the upper Prickly Pear Creek watershed was analyzed by total digestion and dilute-acid partial digestion of ore-related metals (Klein, Thamke, and others, 2003). Sediment in Frohner Meadows creek is highly enriched in ore-related metals as compared with median background concentrations in the upper Prickly Pear Creek watershed (table 5). On the basis of total digestions and dilute-acid partial digestions, metal concentrations at all of the stream bed-sediment sites in stream reaches below the mine and mill areas were determined to be 8-100 times the watershed median-background concentrations for arsenic, cadmium, lead, and zinc. Similarly, the median copper concentration in the watershed area was determined to be 7 times the median-background concentrations produced by dilute-acid partial digestion and 4 times the concentration produced by total digestion. Frohner Meadows creek is similarly enriched in comparison with the mean crustal abundance of these elements in granitic rocks (table 5). These data illustrate that Frohner Meadows creek is enriched in ore-related metals relative to their mean crustal abundance and to regional background concentrations.

Comparison of the same data (table 5) with CBPEC concentrations (table 6) shows that in Frohner Meadows creek median concentrations (determined by total digestion and dilute-acid partial digestions) exceed the CBPEC concentrations for arsenic, cadmium, lead, and zinc by 5 to nearly 30 times. Concentrations of these ore-related metals in this creek at these sites - downstream from the mine and mill areas-far exceed any stream bed-sediment standard value that attempts to define aquatic health. Median copper concentrations in Frohner Meadows creek are similar to the CBPEC for copper, which suggests that copper concentrations are a lesser threat to aquatic health in Frohner Meadows than are the other ore-related metals.

\section{Downstream-Concentration Plots of Ore-Related Metals}

A type of plot called a downstream-concentration plot aids identification of the sources of ore-related metals and the interpretation of downstream changes in metal concentrations. In these plots, the measured concentration at a site and a constant rate of change in concentration between adjacent sites are illustrated with a connecting line. These plots provide a graphical tool by which changes in metal concentration can be evaluated in terms of sources and chemical and physical processes. Concentrations of metals derived from dilute-acid partial-digestion analyses were used to construct the plots because the metals liberated by dilute-acid digestion are more readily available to stream water and to aquatic organisms. The chemical analyses of samples treated by this method are given in table 8 of Klein, Thamke, and others (2003).
Sites $\mathrm{L}-152$ through $155, \mathrm{~L}-4$, and $\mathrm{L}-4 \mathrm{a}$ are outside the study area and lie downstream, in that order, from site L-156 in upper Lump Gulch (fig. 3). These sites were included in the downstream plots to illustrate the downstream effect of Frohner Meadows on stream bed sediment in upper Lump Gulch. Data for those sites are summarized in Klein, Cannon, and Fey (2003).

Changes in dilute-acid partial-digestion concentrations of arsenic, cadmium, copper, lead, and zinc in stream bed sediment as a function of distance downstream are shown in figures 17-22. In each figure, an element's concentration is represented on the vertical axis, and the downstream distance is represented on the horizontal axis. Downstream distances were measured from an arbitrary starting point; to the left of the figure is upstream and to the right is downstream. In each plot, a green solid line connects metal-concentration data for sites along Frohner Meadows creek, beginning above site L-2 and continuing downstream through upper and lower Frohner Meadows to site L-3b. Lump Gulch begins at site L-158, which lies upstream from a small, sediment-filled reservoir. Site L-156 (fig. 3) is at the junction of the tributaries that drain the Panama mine meadows (fig. 3) and Frohner Meadows. Below this reservoir, the stream in Lump Gulch flows from site $\mathrm{L}-156$ to $\mathrm{L}-4$ and beyond. A solid yellow line connects metal concentration data for stream bed sediment from the Panama mine tributary. A dashed green line connects lower Frohner Meadows with the Panama mine meadows tributary. Water from lower Frohner Meadows flows from the meadow primarily in a channel at the eastern end at site $\mathrm{L}-3 \mathrm{~b}$, as well as through a second channel that emerges from the meadow's southern edge and connects with the Panama mine tributary. The Panama mine tributary mostly is unaffected by contaminated sediment and appears to dilute the concentrations of orerelated metals in sediment in Frohner Meadows creek below their convergence near site L-156.

\section{Arsenic}

The dilute-acid partial-digestion arsenic concentration (10 ppm) above the Frohner mine (site L-2, fig. 17) was near the background concentration of $6.6 \mathrm{ppm}$ (table 5). The next site downstream, L-162, is just below the historical Frohner mill site, where a large volume of crushed-ore material is present at the surface and in an old ore bin. Erosion has distributed the crushed ore down the relatively steep slope into Frohner Meadows creek. The arsenic concentration in stream bed sediment here was higher than 2,000 ppm. Downstream through upper and lower Frohner Meadows, arsenic concentrations remained variably high relative to the upstream samples. A general trend toward lower concentrations downstream between sites L-165 and $\mathrm{L}-161$ probably reflects dilution by sediment containing a lower arsenic concentration. The small increase in arsenic concentration in the upstream site (L-159) in lower Frohner Meadows probably was due to the addition of arsenic-enriched material from mill tailings situated at the western end of the lower meadow near bulk sample site LFM-1 (fig. 3). 
Table 5. Median trace metal concentrations of regional-background stream bed-sediment samples in upper Prickly Pear Creek watershed (Klein and others, 2001, table 2) and median concentrations in stream bed sediments in Frohner Meadows study area.

[Mean crustal abundances for granitic rocks are total analyses and are from Rose and others (1979). All concentrations in parts per million. Conc., concentration; (s.d.), standard deviation; $\mathrm{n}$, number of samples]

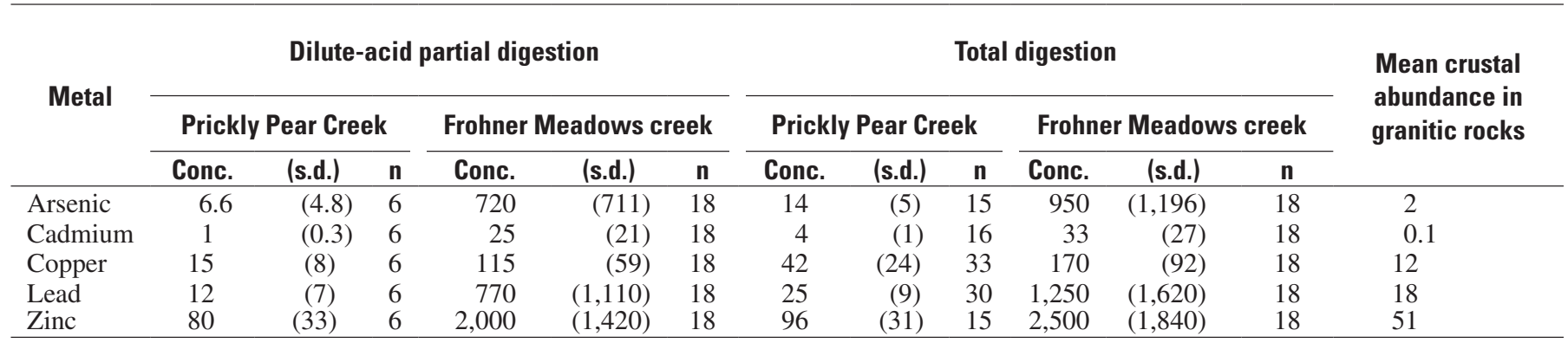

Table 6. Summary of consensusbased probable-effect concentrations of ore-related metals in stream bed sediment (MacDonald and others, 2000).

[CBPEC, consensus-based probable-effect concentration; ppm, parts per million]

\begin{tabular}{lc}
\hline Element & $\begin{array}{c}\text { CBPEC } \\
\text { (ppm) }\end{array}$ \\
\hline Arsenic & 33 \\
Cadmium & 4.98 \\
Copper & 149 \\
Lead & 128 \\
Zinc & 459 \\
\hline
\end{tabular}

At site $\mathrm{L}-158$, the concentration of arsenic sharply increases. Manganese and iron concentrations also increase markedly, perhaps because those metals, which are dissolved in spring water in Frohner Meadows, oxidize and precipitate out as spring water enters the creek (between sites L-3b and L-158). The increase in arsenic concentration may be linked to oxidation of arsenic-rich ground water in lower Frohner Meadows. However, the extremely high lead concentration at this site (see subsequent section) is evidence against its transport in solution and suggests that lead is transported by detrital processes. Arsenic concentration decreases substantially between site L-158, just above the sediment-filled reservoir in upper Lump Gulch, and the reservoir outlet (site L-156). On the basis of field observations such as flood-plain width, it is likely that the Panama mine tributary contributes far more detrital material to the filled reservoir than does Frohner Meadows creek. Field observation above site L-3b suggests that little coarse detrital material leaves lower Frohner Meadows because of its numerous dams, ponds, and wetlands. Very low arsenic concentrations at sites $\mathrm{L}-151$ and $\mathrm{L}-157$ confirmed that stream bed sediment from the Panama mine tributary likely is not contaminated. The tie line between $\mathrm{L}-157$ and L-156 (fig. 17) illustrates that stream bed sediment having low arsenic concentration from the Panama mine tributary dilutes the arsenic concentration in typical Frohner Meadows creek concentrations below the junction of these streams.

\section{Cadmium}

As with arsenic, the cadmium concentration at site $\mathrm{L}-2$ is quite low and equals the median for background sites (figure 18 , table 5). The concentration rises to $16 \mathrm{ppm}$ below the Frohner mill site (L-162). Tailings from the mill site were not particularly high in cadmium; samples from sites FMB-1 and 2 contained 9 and 4 ppm, respectively (table 6 of Klein, Thamke, and others (2003)), so the mill tailings probably contribute little cadmium to the stream bed sediment. However, the cadmium concentration in samples from site $\mathrm{L}-100$ increased substantially to $46 \mathrm{ppm}$. Cadmium is quite soluble and mobile at the nearly neutral $\mathrm{pH}$ of the stream waters found throughout Frohner Meadows and, as a result, can be transported in solution as well as in detrital mineral grains. It also can be removed from solution by sorption on iron or manganese oxyhydroxides (Horowitz, 1991). This study found strong correlations between dilute-acid partial-digestion concentrations of iron and cadmium in stream bed sediment and similarly derived concentrations of manganese and cadmium. The $r^{2}$ (correlation coefficient) for iron and cadmium is 0.85 , and the $r^{2}$ for manganese and cadmium is 0.71 . The diluteacid partial-digestion concentrations of iron and manganese in samples from core L-100 were high-23,000 and 16,000 ppm, respectively (table 8 of Klein, Thamke, and others, 2003; fig. 18 , this report). Thus, the large amount of iron and manganese oxyhydroxide that coats stream bed sediment at that site may scavenge cadmium from the dissolved phase and produce sediment concentrations of cadmium that are much higher than those in core $\mathrm{L}-162$. This process-the scavenging, by iron 


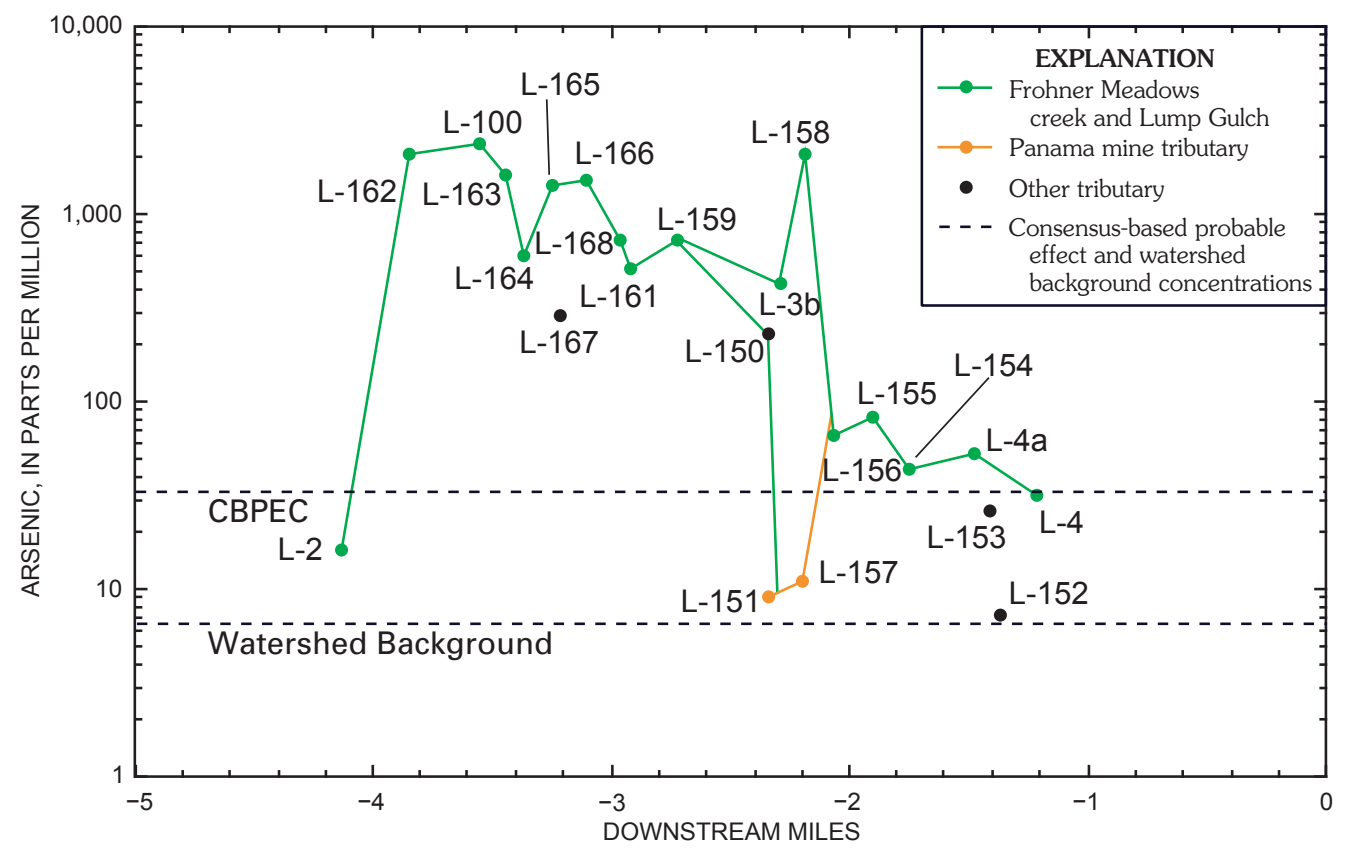

Figure 17. Downstream-concentration plot of arsenic in stream bed sediment from Frohner Meadows creek and Lump Gulch. Concentrations derived by dilute-acid partial-digestion analyses.

and manganese oxyhydroxides in stream bed sediment, of cadmium dissolved in contaminated surface water-probably is responsible for the high concentrations of cadmium in stream bed sediment at many sites in the study area.

The concentration of cadmium in stream bed sediment decreased overall downstream from site L-100 to site L-164 (fig. 18), probably from dilution by unenriched stream bed sediment. Then, from site L-165 in upper Frohner Meadows, concentrations increased downstream through the eastern end of lower Frohner Meadows site L-3b.

Cadmium also is transported out the south outlet of lower Frohner Meadows, as we infer from the high concentration (40 ppm) in samples from site L-150. Stream bed sediment from the Panama meadows tributary diluted the south outlet sediment as seen at site $\mathrm{L}-157$, where the cadmium concentration dropped to $3 \mathrm{ppm}$. However, the cadmium dilution in samples from site $\mathrm{L}-156$ was not as marked as that for arsenic, probably because dissolved cadmium continues to be transported out of Frohner Meadows and deposited onto iron and manganese oxyhydroxide grain coatings, even during low-flow conditions when clastic transport is minimal. This process is relatively independent of the effects of dilution by clastic sediments.

The downstream-concentration plot of iron and manganese (fig. 19) shows that the overall patterns of both metals are similar to that of cadmium. This similarity supports the hypothesis that dissolved cadmium accumulates in sediment by sorption on iron and manganese oxyhydroxide grain coatings. The highest concentrations of iron and manganese are at site $\mathrm{L}-158$. Most concentrations of ore-related metal below this site decrease sharply, a trend that suggests that some of the transported metals (cadmium and zinc) may be removed from the streamwater by sorption on manganese and iron grain coatings near this site. Similar effects also may occur in the lower part of lower Frohner Meadows above site L-3b.

Concentrations of dissolved arsenic, cadmium, and zinc in streamwater varied widely in different seasons at site $\mathrm{L}-3 \mathrm{~b}$. In addition, the concentrations of these constituents varied widely in stream bed sediments collected in October 2000 and July 2001. These large variations may be responses to temporal changes in water chemistry related to solubility reactions between surface water and iron and between manganese oxyhydroxide grain coatings on stream bed sediments and surficial deposits in this marshy area. Alternatively, some of the variation may be related to sample variation. At site $\mathrm{L}-3 \mathrm{~b}$, which is at the outlet of lower Frohner Meadows, and at site L-100, we collected a sample in October 2000 and in July 2001. In both samples, sediment concentrations of all ore-related trace metals were lower in 2001 than in 2000. However, the major elements aluminum, calcium, potassium, and sodium, which were all higher in 2001, indicate that the sample had a higher proportion of lithic material (decomposed, plutonic rock-forming minerals) that diluted the ore-related trace metals. The iron and manganese concentrations in the 2001 samples were lower than they were in 2000 ( 58 percent and 33 percent at $\mathrm{L}-3 \mathrm{~b}$, respectively). The lower concentrations of these scavenger elements generally reduced the concentrations of the other elements. Whether the lower concentrations of iron and manganese were due to temporal differences in water chemistry or to the heterogeneity of material at these sites is not known. 


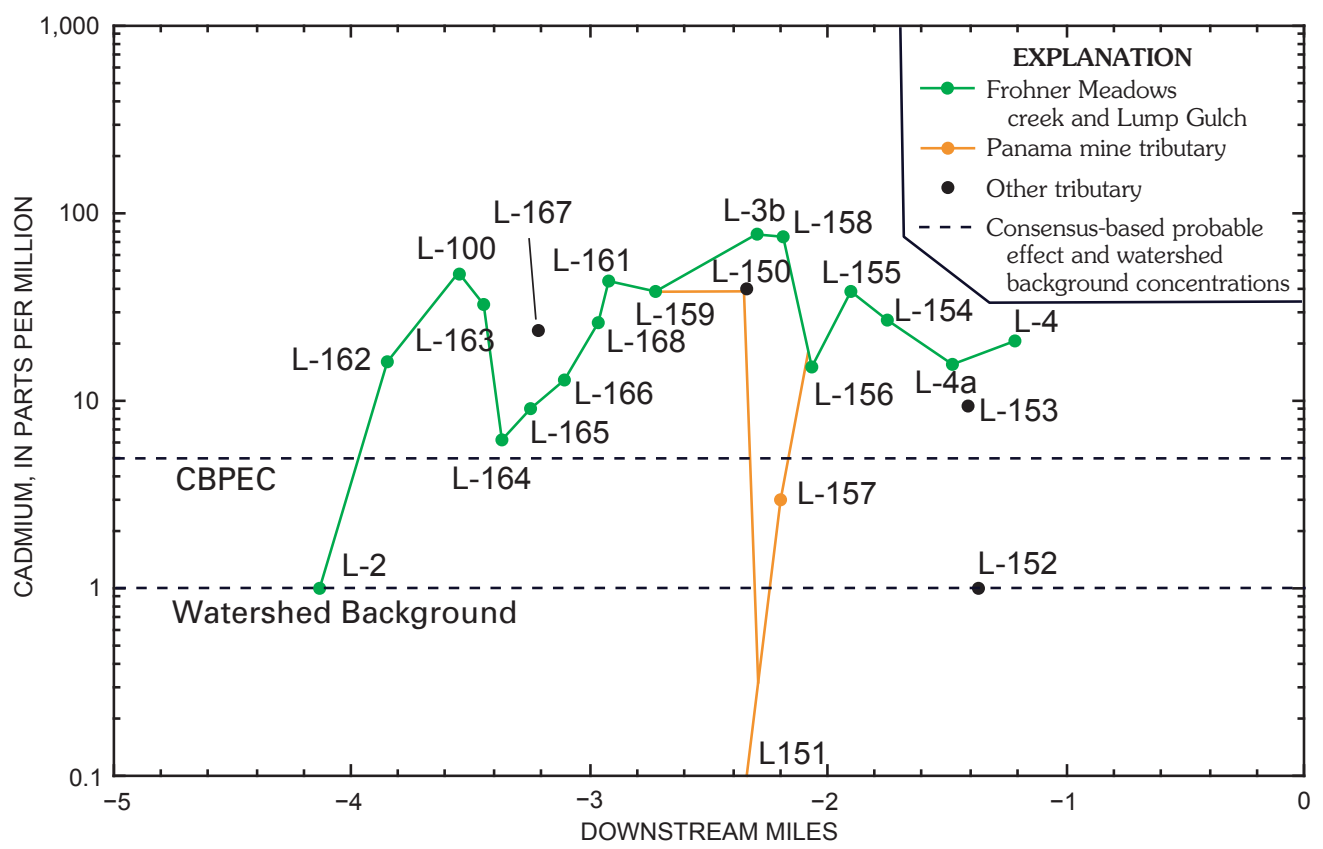

Figure 18. Downstream-concentration plot of cadmium in stream bed sediment from Frohner Meadows creek and Lump Gulch. Concentrations derived by dilute-acid partial-digestion analyses.

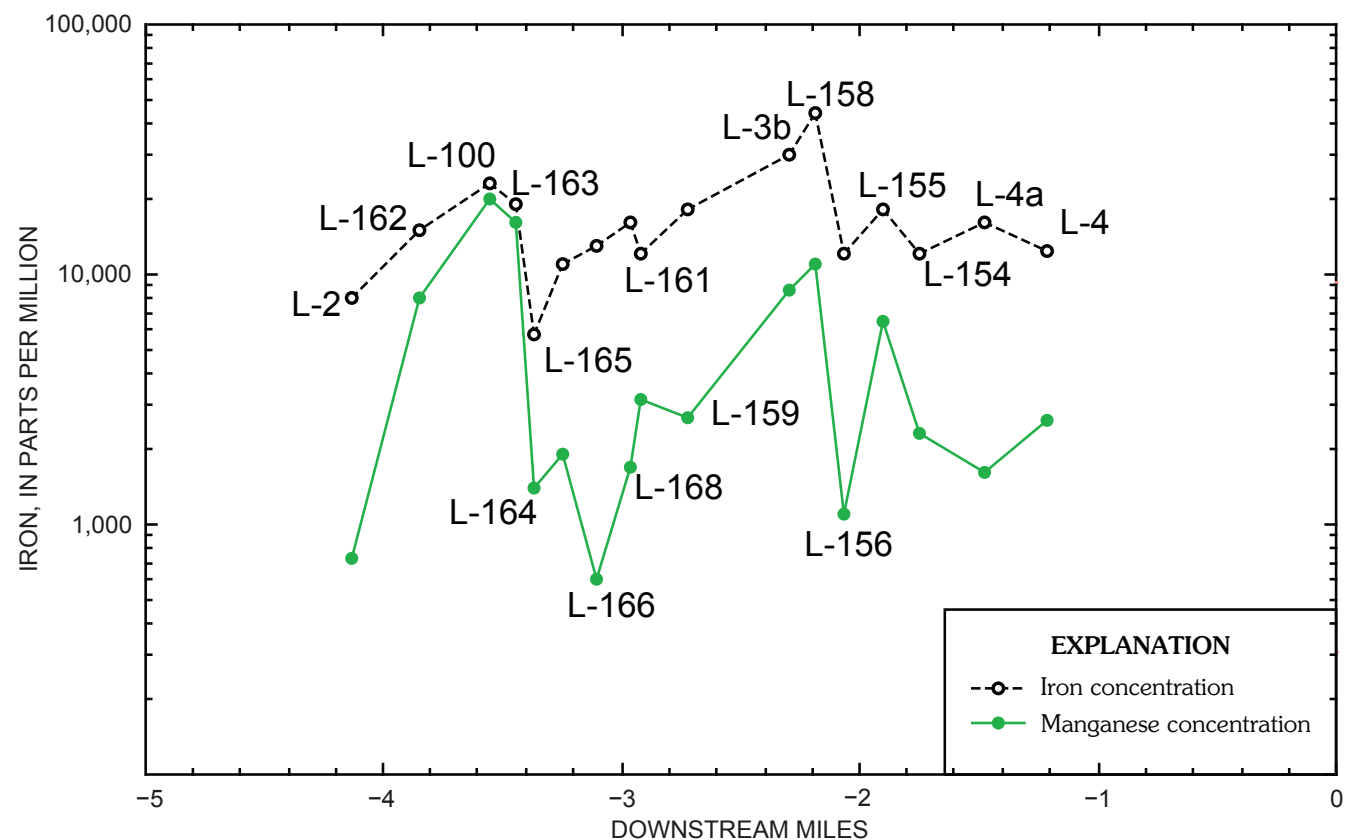

Figure 19. Downstream-concentration plot of iron and manganese in stream bed sediment from Frohner Meadows creek and Lump Gulch. Concentrations derived by dilute-acid partial-digestion analyses. 


\section{Copper}

Copper concentrations in the stream bed sediment throughout Frohner Meadows are relatively low because the mineralized rock in the Frohner and Nellie Grant deposits contains only low concentrations of copper. The CBPEC of $149 \mathrm{ppm}$ was exceeded at only three sites (fig. 20). Site L-2 had a concentration of 19 ppm, slightly higher than the median background copper concentration $(15 \mathrm{ppm})$ in this study. Below the Frohner mill site, at sites L-162 and L-100, copper concentrations were 120 and 200 ppm, respectively. Dilution by streambed sediment reduced the concentration to $74 \mathrm{ppm}$ at site $\mathrm{L}-164$. Between sites $\mathrm{L}-165$ and $\mathrm{L}-166$, Frohner Meadows creek passes through dispersed mill tailings (fig. 3) that increase the concentration of copper in stream bed sediment. The addition of unenriched stream bed sediment diluted the copper concentration at site L-161, at the lower end of upper Frohner Meadows. Samples from site L-159 contained slightly more copper, possibly from the mill tailings impounded at the west end of lower Frohner Meadows (fig. 3 ). The $r^{2}$ correlation coefficients for iron and manganese on copper were only 0.48 and 0.50 , respectively. Thus, copper is more likely transported in detrital weathering products or with organic matter to which it readily binds.

The concentration of copper was much greater in samples from site $\mathrm{L}-158$ than in those from site $\mathrm{L}-3 \mathrm{~b}$. The cause of this increase in copper, and in arsenic, manganese, and iron, is not clear. Copper concentrations markedly decline between site $\mathrm{L}-158$, just above the filled reservoir, and $\mathrm{L}-156$, the outlet to the reservoir (fig. 20). Dilution by uncontaminated sediment from the Panama meadows tributary apparently reduces the dilute-acid extractable copper in Frohner Meadows creek sediment to $31 \mathrm{ppm}$ at site L-156. Frohner Meadows stream bed sediment that is enriched in copper likely will have only minor environmental effects, because copper concentrations are only slightly higher than regional background concentrations and crustal-abundance concentrations.

\section{Lead}

Of the five ore-related metals discussed here, lead is the least soluble and least correlated with iron and manganese. The $r^{2}$ correlation coefficients of iron and manganese with lead were only 0.05 and 0.37 respectively. These low correlations imply that lead is transported as detrital material. Dilute-acid partial-digestion concentrations of lead from the stream bed sediment probably represent primary galena $(\mathrm{PbS})$ in the samples, because galena was readily soluble in the warm, dilute $\mathrm{HCl}$ used in the dilute-acid partial digestion.

High concentrations of lead in stream bed sediments of Frohner Meadows creek are due to an influx from the Frohner mine and mill site (fig. 3). In samples taken above the mine (site L-2), the dilute-acid partial-digestion concentration was low (20 ppm), close to the median-background concentration (12 ppm) and well below the CBPEC (128 ppm) (table 6, fig. 21). Contributions of tailings material from the Frohner mill site (and probably from the Frohner mine, although a sample was not taken directly below the mine site) increase the lead concentration in stream bed sediment to $3,500 \mathrm{ppm}$ at site L-162. Dilution by sediment from other sources produced a downstream decrease in the concentration at site L-164 to 940 ppm. Dispersed mill tailings in the meadow between sites

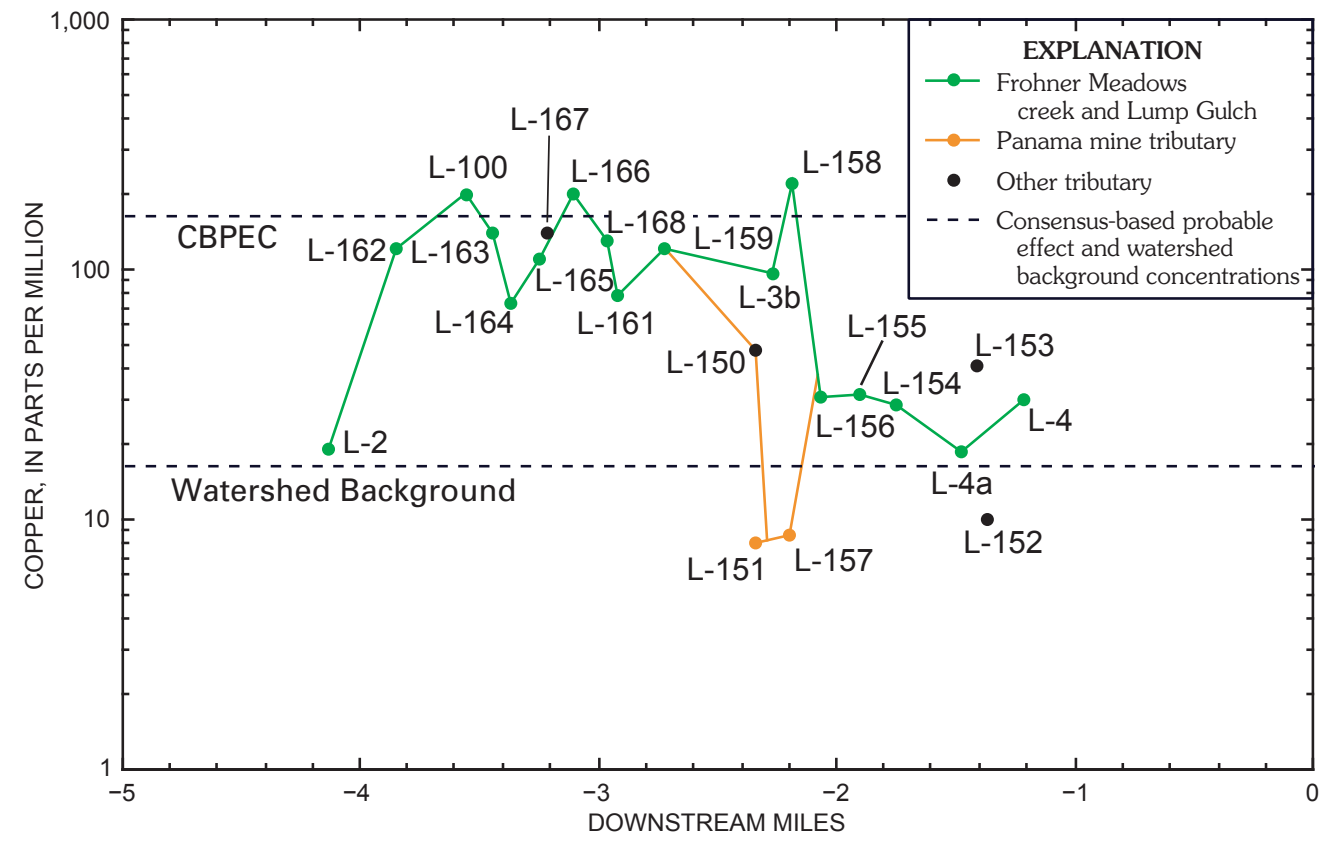

Figure 20. Downstream-concentration plot of copper in stream bed sediment from Frohner Meadows creek and Lump Gulch. Concentrations derived by dilute-acid partial-digestion analyses. 
L-164 and L-166 contribute additional contaminated material that raises the lead concentration at site $\mathrm{L}-166$ to 1,800 ppm; dilution by other meadow sediment again lowers the lead concentration to $480 \mathrm{ppm}$ at site $\mathrm{L}-161$.

A bulk sample of the fine-grained mill tailings (sample LFM 1) from the delta at the west end of lower Frohner Meadows contained 8,100 ppm total lead (table 6, Klein, Thamke, and others, 2003). These mill tailings probably contribute to the increase in the dilute-acid partial-digestion concentration of lead at site L-159 (960 ppm). The dilute-acid partial-digestion lead concentration (220 ppm) in samples from site L-3b was much lower, probably because only a small amount of detrital galena is transported through lower Frohner Meadows. The meadow, with its numerous abandoned beaver ponds, other ponds, and marshes, effectively traps detrital sediment under most stream-discharge conditions. The dilute-acid partial-digestion concentration of lead (1,000 ppm) in samples from site L-158 was enigmatically high, because solution transport cannot be invoked to explain the large rise. One explanation is that a past high-energy flushing event moved fine-grained detrital lead through the meadows, and material having high lead concentrations settled out in the stream where the slope changes to a more gentle gradient (near site L-158). Stream bed sediment of the Panama mine tributary dilutes lead concentrations at site L-156 (fig. 21). Between sites $\mathrm{L}-158$ and $\mathrm{L}-156$ lead concentration drops by a factor of about 14, whereas cadmium concentration drops by a factor of only 5 (fig. 18). Because cadmium can be transported in solution as well as by detrital grains, a higher proportion remains in stream bed sediment downstream from the junction of the two creeks.

\section{Zinc}

Zinc and cadmium display isochemical behavior. Cadmium commonly substitutes for zinc in sphalerite, the principle zinc ore mineral in the local ore deposits, and strongly covaries with zinc in stream bed sediments in the study area. The dilute-acid partial-digestion concentration of zinc in stream bed sediment above the Frohner mine and mill sites (L-2) was 49 ppm (fig. 22), below the median-background concentration of $80 \mathrm{ppm}$ (table 5) and far below the CBPEC of 459 ppm (table 6). Below the Frohner mill site (L-162), the dilute-acid partial-digestion concentration of zinc in stream bed sediment $(1,400 \mathrm{ppm})$ was higher than the total zinc concentration in the mill waste material itself (400-1,100 ppm). Farther downstream at site L-100, the dilute-acid partial-digestion zinc concentration $(3,300 \mathrm{ppm})$ was higher still. This spike probably reflects sediments enriched by iron or by manganese oxyhydroxides that have successfully scavenged dissolved zinc. The $r^{2}$ correlation coefficients of iron and manganese with zinc were 0.86 and 0.71 , respectively. Zinc is transported in the dissolved phase from the Frohner mine area on Frohner Meadows creek and then is trapped by sediment grain coatings and concentrated in stream bed sediment above site L-100.
As with the metals already discussed, between sites L-100 and L-164 zinc concentrations are diluted, likely by unenriched stream bed sediment from other sources. Between sites L-164 and L-161, zinc concentration increases again, probably from an influx of dispersed mill tailings between L-165 and L-166 and from the accumulation of zinc scavenged from solution by iron and manganese oxyhydroxides. The total zinc concentration of the mill tailings submerged at the west end of lower Frohner Meadows was 11,000 ppm (Klein, Thamke, and others, 2003, table 6). It is not clear if zinc is moved by direct transport to site $\mathrm{L}-159$, because the dilute acid partial-digestion concentration of zinc at that site is the same as at site L-161, which is upstream from the upper end of the meadow. However, because the dilute-acid partialdigestion concentration of zinc increases markedly downstream from site L-159 to higher than 4,600 ppm at site L-3b, it is probable that those mill tailings contribute some soluble zinc to the meadow that is then scavenged by iron and manganese oxyhydroxides near the east end of the meadow.

The familiar dilution of metal in Frohner Meadows creek by sediment from the Panama mine tributary occurs again with zinc (fig. 22). Note that the alternative path for the transport of dissolved zinc from the south side of lower Frohner Meadows through sites $\mathrm{L}-150$ and $\mathrm{L}-157$ is similar to that for cadmium. As with cadmium, iron, and manganese, zinc concentration in stream bed sediment below site L-158 decreased by a factor of only 4 or so, whereas lead decreased by a factor of about 14 and arsenic decreased by a factor of about 32 . These relative decreases again point out the difference in behavior between the metals that are transported primarily in solution (cadmium, copper, and zinc) and those that are transported primarily as (or on) clastic debris (arsenic and lead). Dilute-acid partialdigestion concentrations of zinc increase downstream to site L-155, where the dilute-acid partial-digestion iron and manganese concentrations again are high, a trend that suggests that in this area iron- and manganese-rich grain coatings accumulate substantial amounts of zinc and cadmium dissolved in streamwater.

\section{Hydrology}

The recharge, movement, and discharge of water in the Frohner Basin (fig. 2) are influenced by many factors, including the climate, geology, and topography of the area. About 25 in. of annual average precipitation (U.S. Soil Conservation Service, 1977) recharges ground-water flow systems and small streams that flow into Frohner Meadows. The steep slopes of granitic bedrock that surround Frohner Meadows and the relatively flat areas of unconsolidated sediment in Frohner Meadows form a unique hydrologic system that supports the wetland environment of Frohner Meadows. Ground-water and surfacewater components of the hydrologic system were analyzed to estimate an annual hydrologic budget for Frohner Meadows and to understand the hydrologic regime of the wetlands. 


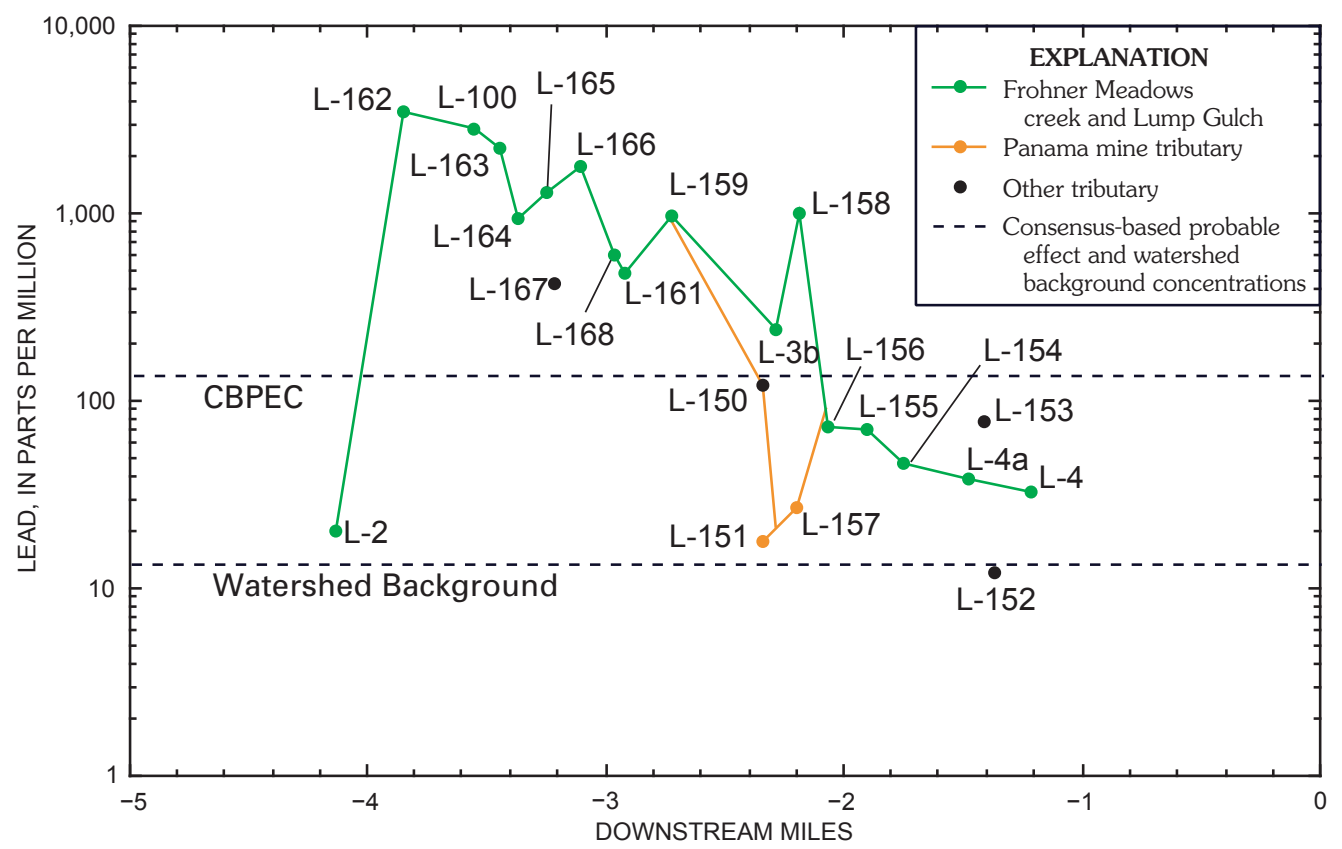

Figure 21. Downstream-concentration plot of lead in stream bed sediment from Frohner Meadows creek and Lump Gulch. Concentrations derived by dilute-acid partial-digestion analyses.

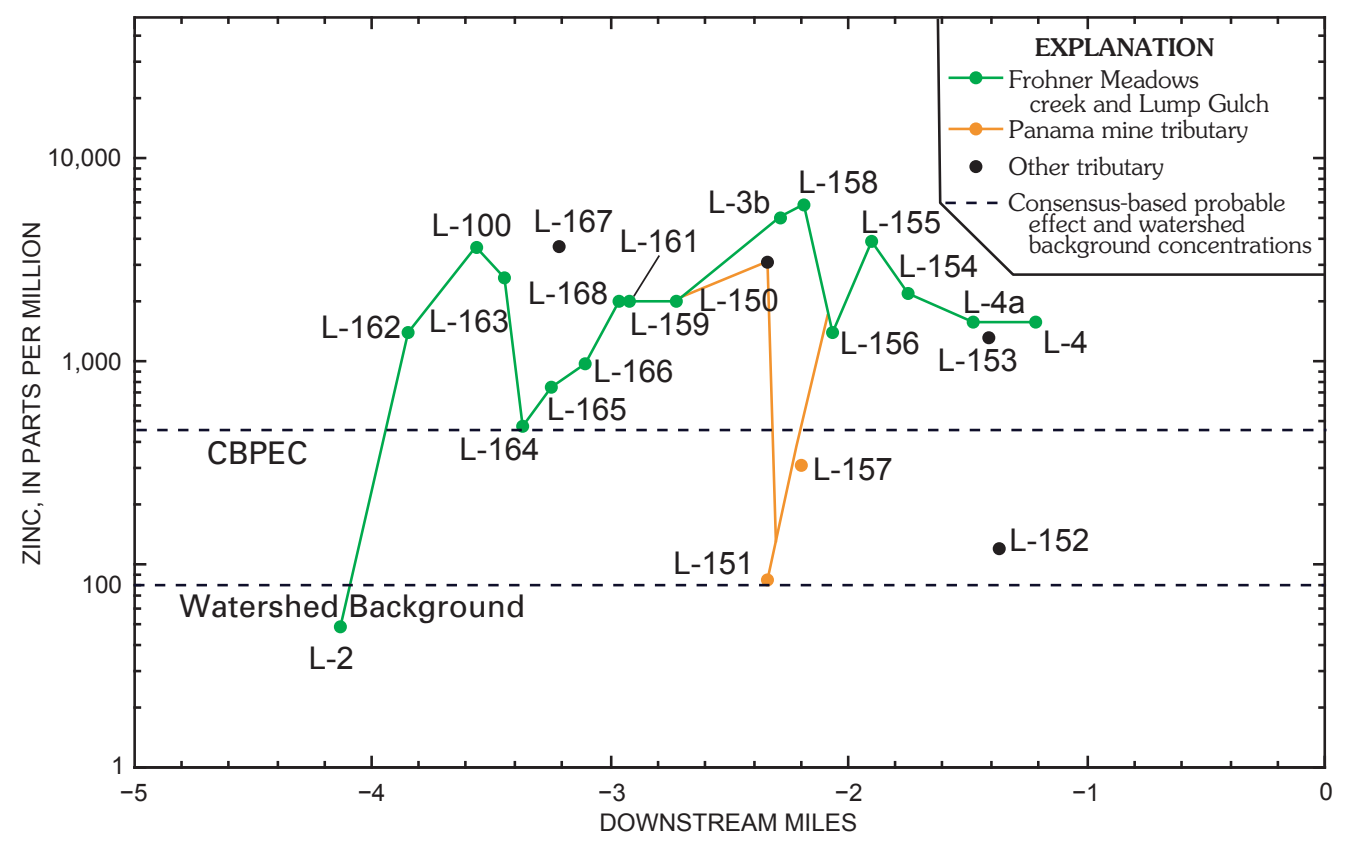

Figure 22. Downstream-concentration plot of zinc in stream bed sediment from Frohner Meadows creek and Lump Gulch. Concentrations derived by dilute-acid partial-digestion analyses. 


\section{Methods of Investigation}

The hydrology of the area was investigated by analysis of surface-water flow, ground-water flow, and hydrogeologic characteristics of the area. A water budget was developed from site-specific measurements of discharge and aquifer characteristics and from regional values of precipitation and monthly discharge. Metal loads into and out of the Frohner Meadows area were estimated from measured values of stream discharge and metal concentrations. Seven shallow wells were installed in upper Frohner Meadows and three wells in lower Frohner Meadows to measure water levels and water quality. Seismicrefraction studies were completed along six lines across the wetland areas of the meadows and analyzed to estimate thickness of saturated unconsolidated sediment overlying the granitic bedrock.

Water-quality samples were collected from both surfaceand ground-water sources in upper and lower Frohner Meadows. Surface-water samples typically were grab samples because discharge was too low to allow the use of a depthintegrating sampler. Surface-water samples were filtered onsite through a $0.45 \mu \mathrm{m}$ syringe filter. Ground-water samples were collected from shallow wells by use of a peristaltic pump, and samples were filtered on-site through a $0.45 \mu \mathrm{m}$ capsule filter. All samples were processed according to procedures described in Wilde and others (1998) and were analyzed by the U.S. Geological Survey National Water Quality Laboratory in Denver, Colo. Analytical methods are described by Faires (1993), Fishman (1993), Fishman and Friedman (1989), Garbarino (1999), Garbarino and Struzeski (1998), Hoffman and others (1996), and Jones and Garbarino (1999).

\section{Ground Water}

The bedrock geology of Frohner Basin, the distribution and thickness of unconsolidated deposits, and the hydraulic characteristics of the unconsolidated deposits and plutonic bedrock that underlie the basin largely control local groundwater flow. Frohner Basin (fig. 2) and the surrounding area are underlain entirely by plutonic rocks of the Boulder batholith, which typically are quartz monzonite and granodiorite (Becraft and others, 1963). Nearly all pore space and permeability in the plutonic rocks is produced by near-surface weathering along joints. Outcrops of the Boulder batholith generally are considerably weathered, and weathering has produced large open fractures along the joints. In many areas, joints in the rocks have sufficiently weathered to leave large, freestanding, rounded boulders. Weathering of the plutonic rocks rapidly decreases with depth, which is clearly evident in many road cuts, mine workings, excavations, and drill holes. In the areas examined, the upper $5 \mathrm{ft}$ of rock typically is highly weathered and has open joints. From about 5 to $50 \mathrm{ft}$ depth, the plutonic rock grades from slightly weathered to unaltered rock, and most joints become tight and contain clay. Below about $50 \mathrm{ft}$, rocks typically are fractured but most fractures are extremely tight, and only a few fracture surfaces are weathered
(McDougal and others, 2004). Gouge typically accompanies even the smallest faults in the batholith (Becraft and others, 1963). Exceptions to these general characteristics may be found along some mineralized zones and large fractures. Hydraulic conductivity of the plutonic rocks typically is very low. At two core holes drilled west of the study area near the continental divide, hydraulic conductivities measured by slug tests were $0.02 \mathrm{ft} /$ day and $0.04 \mathrm{ft} /$ day (Maxim Technologies, 1999). Both slug tests were conducted on fractured or weathered quartz monzonite of the Boulder batholith at depths of 18-43 ft below the land surface. Because of decreasing hydraulic conductivity with depth, most ground-water flow in the Boulder batholith occurs in the uppermost, weathered zone.

Unconsolidated deposits in Frohner Basin contain boulder till and colluvium on hillsides, and in the lowland areas of Frohner Meadows they contain till, alluvium, volcanic ash, and organic deposits. During the Pleistocene Epoch, glacial ice covered much of the highland area west of the study area. From the center of accumulation near upper Cataract Basin, ice moved eastward down Lump Gulch, North Fork Quartz Creek, and South Fork Quartz Creek, where the ice was joined by small tributary glaciers from poorly developed cirques in Frohner Meadows and Park Lake (Becraft and others, 1963). Before the Pleistocene Epoch, Frohner Meadows drained through the North Fork of Quartz Creek; however, Lump Gulch captured this drainage during the Pleistocene (Becraft and others, 1963).

Moraines deposited by glacial ice dammed the preglacial channel of Frohner Meadows creek and formed shallow ponds that subsequently filled with clay, silt, sand, volcanic ash, and organic deposits. Seismic-refraction soundings conducted along upper and lower Frohner Meadows (fig. 14) indicated that till and postglacial sediment overlying bedrock are as much as $45 \mathrm{ft}$ thick in upper Frohner Meadows and $25 \mathrm{ft}$ thick in lower Frohner Meadows. We conclude that a major part of the unconsolidated deposits is till, on the basis of large boulders exposed along the margins of the wetlands and from rocks and till intersected in two types of drill holes: in auger holes drilled in the wetlands for installation of shallow test wells and in shallow cores in the meadow. Sediments overlying the till (in ascending order) typically are poorly sorted, angular, alluvial sand derived from batholith rocks, volcanic ash, organic-rich clay, and peat. Hydraulic conductivity of the organic-rich clay and volcanic ash is very low, and these materials function as confining layers for ground water in the thin underlying zone of alluvial sand.

The volcanic ash, tentatively identified as the Mazama ash, is a massive, tan, biotitic, air-fall deposit. The age of the Mazama ash, which has been estimated by ${ }^{14} \mathrm{C}$ dating to be about $7 \mathrm{Ka}$ (Bacon, 1983), provides an approximate age for the beginning of the development of postglacial ponds. This unit was observed in six cores in Frohner Meadows, ranged in depth from 2 to $4.4 \mathrm{ft}$ below the present surface, and was $0.1-0.8 \mathrm{ft}$ thick where it was intersected.

Discharge of ground water from unconsolidated deposits plays an important role in maintaining the wetland 
environment of Frohner Meadows. Ground water flows from topographically higher areas within Frohner Basin through predominantly thin unconsolidated deposits and the uppermost, weathered zone at the top of bedrock and discharges to land surface in wetland areas of Frohner Meadows. Groundwater discharge, in the form of numerous seeps, was observed along the west, north, and east margins of upper Frohner Meadows and along the west margin of lower Frohner Meadows. By comparing water levels measured in shallow (total depths 5-9 ft) test wells on Sept. 26, 2001, with surveyed elevations of land surfaces and nearby water surfaces (table 7), we documented a large upward component of groundwater flow. Ground-water levels were higher than land surface at three wells (FM-4, FM-5, and FM-7) and were higher than the adjacent pond or stream surface at three other wells (FM-1, FM-3, and FM-8). Upward hydraulic gradients were as much as $0.33(1.05 \mathrm{ft} / 3.0 \mathrm{ft})$ at well FM-5.

Discharge of ground water to wetlands in Frohner Meadows contributes to stream discharge in Frohner Meadows creek. Discharge measurements were made at 12 sites on Frohner Meadows creek and its tributaries (fig. 14) several times in 2001. Small gains in discharge were measured in the downstream part of upper Frohner Meadows. Between measurement sites $\mathrm{H}$ and I, discharge on June 26, 2001, increased from $0.76 \mathrm{ft}^{3} / \mathrm{s}$ to $0.86 \mathrm{ft}^{3} / \mathrm{s}$, and on October 10,2001 , discharge increased from $0.09 \mathrm{ft}^{3} / \mathrm{s}$ to $0.15 \mathrm{ft}^{3} / \mathrm{s}$. Measurements made on other dates or at other sites indicated small increases or small decreases in discharge through different sections of Frohner Meadows. Many of the differences in discharge were within the measurement error of the methods used. However, ground water likely discharges to Frohner Meadows creek throughout much of the length of the wetlands, as is indicated by observed flow of seeps toward the stream and by measured ground-water levels that generally are higher than stream surface or land surface.

Downstream from lower Frohner Meadows, discharge of ground water through moraine and bedrock likely is small because till and batholith rocks generally have low hydraulic conductivities. A likely range of hydraulic conductivity, on the basis of measured hydraulic conductivity in the Boulder batholith (Maxim Technologies, 1999) and published values for till (Bouwer, 1978), is 0.003 to $0.3 \mathrm{ft} /$ day; a median value is $0.03 \mathrm{ft} / \mathrm{day}$. We calculated that the flow (Darcy equation, see Lohman, 1972) of ground water through till and the upper weathered zone of bedrock ranges from 0.0001 to $0.01 \mathrm{ft}^{3} / \mathrm{s}$ and has a median of $0.001 \mathrm{ft}^{3} / \mathrm{s}$, on the basis of the above values of hydraulic conductivity, a width of $600 \mathrm{ft}$, a thickness of $60 \mathrm{ft}$, and a gradient of $0.1(80 \mathrm{ft} / 800 \mathrm{ft})$.

\section{Surface Water}

Frohner Meadows creek drains Frohner Basin into Lump Gulch and eventually into Prickly Pear Creek (fig. 3). Frohner Meadows creek flows adjacent to the Frohner mine and enters the wetlands of upper Frohner Meadows in the northwestern part of the meadows. Several small tributaries join Frohner
Meadows creek, including an unnamed tributary that drains from the Nellie Grant mine reclamation area. All water that drains from upper Frohner Meadows through Frohner Meadows creek flows into lower Frohner Meadows. In the western part of lower Frohner Meadows, a small tributary that drains the steep slopes west of the meadows joins Frohner Meadows creek. At a beaver pond in the eastern part of lower Frohner Meadows, Frohner Meadows creek splits into two separate outflow channels. The two channels eventually rejoin in Lump Gulch. The drainage area of Frohner Meadows creek at the outlet of upper Frohner Meadows is $1.04 \mathrm{mi}^{2}$. At the outlets of lower Frohner Meadows, the creek has a drainage area of $1.30 \mathrm{mi}^{2}$. The drainage area of lower Frohner Meadows was measured as all drainage area upstream from Jefferson County Road 1878, where it crosses Frohner Meadows creek (near sites L-3a and L-3b, fig. 14).

Frohner Meadows creek has no gaging station that can be used to measure daily, mean monthly, or annual discharge values; therefore, regression equations (Parrett and Johnson, 1989) that relate monthly discharge characteristics to drainage area and mean annual precipitation were used to estimate mean monthly and annual discharge. The regression equations yielded a mean annual discharge of $0.98 \mathrm{ft}^{3} / \mathrm{s}$ for Frohner Meadows creek at the outlet of lower Frohner Meadows. Calculated mean monthly discharge ranged from $0.19 \mathrm{ft}^{3} / \mathrm{s}$ in January to $3.8 \mathrm{ft}^{3} / \mathrm{s}$ in May (table 8).

Base flow of Frohner Meadows creek, which is derived from ground-water discharge, also was estimated from measured discharge in nearby streams that drain the areas underlain by the Boulder batholith and flow across geologic substrates similar to those in the study area. Base flow of Basin Creek, Cataract Creek, and High Ore Creek, determined from winter measurements made from 1996 to 2000 (Nimick and Cleasby, 2000; T.E. Cleasby, unpub. data, 2000), averaged $0.11 \mathrm{ft}^{3} / \mathrm{s}$ from each square mile of drainage area. If we assume that Frohner Meadows creek has similar runoff characteristics, then discharge at the outlet of lower Frohner Meadows would be about $0.15 \mathrm{ft}^{3} / \mathrm{s}$ during base-flow conditions. Actual discharge of Frohner Meadows creek measured during base-flow conditions on October 11, 2000, was $0.11 \mathrm{ft}^{3} / \mathrm{s}$ at site $\mathrm{L}-3$ (sites L-3a and $\mathrm{L}-3 \mathrm{~b}$ combined, fig. 14). On the basis of both calculated and measured values of stream discharge, ground-water discharge is estimated to contribute about $0.15 \mathrm{ft}^{3} / \mathrm{s}$ to Frohner Meadows creek during base-flow conditions. A larger volume of ground water discharges into Frohner Meadows creek during and after large rainfall events and spring snowmelt.

\section{Water Budget}

An annual water budget for Frohner Meadows and Frohner Basin was developed to evaluate relative volumes of water that discharge through surface water, ground water, and evapotranspiration. This budget was developed by use of published values of long-term precipitation and evaporation and of calculated values of stream discharge and ground-water flow. Calculations of stream discharge and ground-water flow 
Table 7. Water levels in wells and at surface-water sample sites in Frohner Meadows, September 24-26, 2001.

[Relative elevations (in feet) were surveyed from temporary bench marks; bench-mark elevations estimated from 1:24,000-scale topographic map, National Geodetic Vertical Datum of 1929. +, water level above land surface; NA, not applicable]

\begin{tabular}{|c|c|c|c|c|}
\hline Site name & $\begin{array}{c}\text { Elevation } \\
\text { of land } \\
\text { surface }\end{array}$ & $\begin{array}{c}\text { Water } \\
\text { level } \\
\text { below land } \\
\text { surface }\end{array}$ & $\begin{array}{c}\text { Date } \\
\text { measured }\end{array}$ & $\begin{array}{c}\text { Elevation } \\
\text { of water } \\
\text { surface }\end{array}$ \\
\hline Well FM-1 & 6582.13 & 0.96 & $9 / 26 / 2001$ & 6581.2 \\
\hline Well FM-2 & 6583.79 & 1.10 & $9 / 26 / 2001$ & 6582.7 \\
\hline Well FM-3 & 6587.29 & 0.79 & $9 / 26 / 2001$ & 6586.5 \\
\hline Well FM-4 & 6597.89 & +0.43 & $9 / 26 / 2001$ & 6598.3 \\
\hline Well FM-5 & 6595.11 & +1.05 & $9 / 26 / 2001$ & 6596.2 \\
\hline Well FM-6 & 6583.76 & 1.97 & $9 / 26 / 2001$ & 6581.8 \\
\hline Well FM-7 & 6576.51 & +0.16 & $9 / 26 / 2001$ & 6576.7 \\
\hline Well FM-8 & 6541.55 & 0.45 & $9 / 26 / 2001$ & 6541.1 \\
\hline Well FM-9 & 6530.03 & 1.10 & $9 / 26 / 2001$ & 6528.9 \\
\hline Well FM-10 & 6517.50 & 0.76 & $9 / 26 / 2001$ & 6516.7 \\
\hline Frohner Meadows Creek west of well FM-1 (water surface) & NA & NA & $9 / 24 / 2001$ & 6580.7 \\
\hline Beaver pond at well FM-7 & NA & NA & $9 / 24 / 2001$ & 6575.9 \\
\hline Beaver pond between wells FM-1 and FM-7 & NA & NA & $9 / 24 / 2001$ & 6579.2 \\
\hline Stream west of well FM-6 (water surface) & NA & NA & $9 / 24 / 2001$ & 6581.9 \\
\hline Frohner Meadows Creek east of well FM-2 & NA & NA & $9 / 24 / 2001$ & 6582.7 \\
\hline Frohner Meadows Creek by well FM-3 & NA & NA & $9 / 24 / 2001$ & 6585.3 \\
\hline Frohner Meadows Creek, north of well FM-4 & NA & NA & $9 / 24 / 2001$ & 6597.1 \\
\hline Frohner Meadows Creek between wells FM-4 and FM-5 & NA & NA & $9 / 24 / 2001$ & 6595.2 \\
\hline Beaver pond at well FM-5 & NA & NA & $9 / 24 / 2001$ & 6593.8 \\
\hline Upper beaver pond in Upper Frohner Meadows & NA & NA & $9 / 24 / 2001$ & 6600.0 \\
\hline Beaver pond at well FM-8 & NA & NA & $9 / 24 / 2001$ & 6540.1 \\
\hline Stream at well FM-9 (water surface) & NA & NA & $9 / 24 / 2001$ & 6528.9 \\
\hline Beaver pond between wells FM-9 and FM-10 & NA & NA & $9 / 24 / 2001$ & 6526.0 \\
\hline Stream at well FM-10 (water surface) & NA & NA & $9 / 24 / 2001$ & 6516.7 \\
\hline
\end{tabular}

were based on the hydrologic conditions of the study area. Frohner Basin is located at the headwaters of Lump Gulch, and because of its location at the uppermost part of the drainage, all water entering Frohner Meadows likely originates as precipitation within the $1.30 \mathrm{mi}^{2}$ Frohner Basin.

This annual water budget for the basin assumes that long-term changes in storage are zero and that the budget may be expressed as a simple mass-balance equation (2) in which precipitation is equal to all outflows:

$$
\begin{gathered}
\text { Precipitation }=\text { Stream discharge }+ \text { Ground } \text {-water discharge } \\
+ \text { Evapotranspiration }
\end{gathered}
$$

Average annual precipitation for the area between Frohner Meadows and the basin divide is about 25 in. (U.S. Soil Conservation Service, 1977). The average annual volume of precipitation that falls on Frohner Basin is about 1,733 acre-ft, and this volume of water equals all outflows from the basin. The stream-discharge component of the annual budget is about $0.98 \mathrm{ft}^{3} / \mathrm{s}$ (709 acre-feet per year (acre-ft/yr)), of which at least $0.15 \mathrm{ft}^{3} / \mathrm{s}$ (108 acre-ft/yr) originates as ground-water flow within the basin. Ground water that leaves the basin as flow through till and granite is estimated at about 1 acre-ft/yr, although it could range from 0.09 to 9 acre-ft/yr. A large volume of water leaves Frohner Basin through evapotranspiration. Potential evapotranspiration rates for wetlands are greater than those for forest or grassland; therefore, total evapotranspiration for the basin is subdivided into evapotranspiration from wetland and evapotranspiration from forest.

Evapotranspiration for the wetland area of Frohner Meadows can be calculated as a free-water-surface evaporation and is about $30 \mathrm{in} . / \mathrm{yr}$ (National Oceanic and Atmospheric Administration, 1982). Actual evapotranspiration from the wetlands probably is only slightly less than potential evaporation because of the large areas of ponded water, wet soils, and vegetation, all of which draw on an unlimited water supply. Evapotranspiration of $30 \mathrm{in}$./yr from the 29.7 acres of wetlands 
Table 8. Calculated mean monthly discharge and annual discharge of Frohner Meadows creek.

\begin{tabular}{lcc}
\hline \multicolumn{1}{c}{$\begin{array}{c}\text { Discharge } \\
\text { interval }\end{array}$} & $\begin{array}{c}\text { Cubic feet/ } \\
\text { second }\end{array}$ & Acre-feet \\
\hline October & 0.39 & 24 \\
November & 0.28 & 17 \\
December & 0.23 & 14 \\
January & 0.19 & 12 \\
February & 0.20 & 11 \\
March & 0.25 & 16 \\
April & 0.97 & 58 \\
May & 3.8 & 234 \\
June & 3.3 & 197 \\
July & 1.0 & 63 \\
August & 0.61 & 38 \\
September & 0.43 & 25 \\
& & \\
Annual & 0.98 & 709 \\
\hline
\end{tabular}

of Frohner Meadows is equivalent to 74 acre-ft/yr. Evapotranspiration from the 802 acres of forest and grasslands in the Frohner Basin can be calculated as a remainder in equation 2. Rearranging equation 2 gives the following:

$$
\begin{gathered}
\text { Precipitation }- \text { Stream discharge }- \text { Ground-water discharge - } \\
\text { Evapotranspiration }_{\text {wetland }}=\text { Evapotranspiration }_{\text {forest }}
\end{gathered}
$$

Substituting acre-feet per year values into equation 3:

$$
1733-709-1-74=949 \text { acre-ft/yr. }
$$

The 949 acre-ft/yr of evapotranspiration from the 802 acres of forest or grass is equivalent to a rate of 14 in./yr of evapotranspiration throughout that area, or slightly less than half the rate for wetlands. The water budget for Frohner Basin is summarized in table 9 .

\section{Water Quality}

Samples of ground water and surface water from 22 sites in Frohner Basin were analyzed for specific conductance, $\mathrm{pH}$, common ions, and trace metals. Ground-water sampling sites were selected to allow analysis of ground water flowing (1) into Frohner Meadows from various sources, (2) out of upper and lower Frohner Meadows, and (3) beneath mill tailings deposits in the wetland areas of Frohner Meadows. Surface-water sites were selected to allow analysis of all inflows and outflows as well as to measure changes in water quality within Frohner Meadows. Traceelement loads through Frohner Meadows were calculated from discharge and water-quality data.

\section{Ground Water}

Ground water was sampled at 10 wells in upper and lower Frohner Meadows (sites FM-1 through FM-10, fig. 14 of this report; data are in Klein, Thamke, and others, 2003). Well logs containing lithologic descriptions and well-completion information can be found in Klein, Thamke, and others (2003). All wells were sampled on July 26, 2001, the day after they were purged with a bailer. Four wells (FM-1, FM-3, FM-7, and FM-10) were sampled a second time on October 17, 2001.

Specific conductance of ground water measured on-site during sampling ranged from $144 \mu \mathrm{S} / \mathrm{cm}$ at well FM-5 to 233 $\mu \mathrm{S} / \mathrm{cm}$ at well $\mathrm{FM}-8$. On-site $\mathrm{pH}$ values ranged from 6.0 at well FM-6 to 7.6 at well FM-4. Calcium was the predominant cation in all well-water samples.

Dissolved arsenic was present in most (10 of 14) water samples in concentrations exceeding the Montana numeric water-quality standard for human health of $20 \mu \mathrm{g} / \mathrm{L}$ in ground water (Montana Department of Environmental Quality, 2002). High concentrations of dissolved arsenic were present in water samples from wells FM-1, FM-4, FM-7, FM-8, FM-9, and FM-10. The highest concentration of arsenic was measured in a water sample collected on October 17, 2001, from well FM-1 $(3,380 \mu \mathrm{g} / \mathrm{L})$, which was completed in an area of mill tailings in the central part of upper Frohner Meadows (area A). Water from well FM-4, which was completed in the large impoundment of mill tailings where Frohner Meadows creek enters the west margin of upper Frohner Meadows, also had a high concentration of arsenic $(414 \mu \mathrm{g} / \mathrm{L})$. Water samples collected on July 26, 2001, from wells FM-2, FM-5, and FM-6 on the west, northeast, and east margins of upper Frohner Meadows had the lowest arsenic concentrations; they ranged from $1.0 \mu \mathrm{g} / \mathrm{L}$ at FM-5 to $13.2 \mu \mathrm{g} / \mathrm{L}$ at FM-6 (Klein, Thamke, and others, 2003).

Concentrations of dissolved cadmium, copper, and lead were low in water samples from all wells and were below human-health standards established by the Montana Department of Environmental Quality (2002). Dissolved zinc ranged from less than $1 \mu \mathrm{g} / \mathrm{L}$ in a sample from well FM-3 to 419 $\mu \mathrm{g} / \mathrm{L}$ in a sample from well FM-9.

Water-quality data are available for two additional wells in the area: well MW-1 located just west of the central part of upper Frohner Meadows, adjacent to Nellie Grant creek, and well MW-2 located on private property near the southwestern part of upper Frohner Meadows (fig. 14). Well MW-1 reportedly is screened between 13.5 and $25 \mathrm{ft}$ below land surface in unconsolidated deposits and weathered bedrock; depth to water was about $5 \mathrm{ft}$ below land surface, which is deeper than the stream level in this area (Pioneer Technical Services, 1996). Well MW-2, completed in granitic bedrock, is greater than $100 \mathrm{ft}$ deep, is artesian, and flows about 1-2 gallons/minute (Pioneer Technical Services, 1996). Five water samples collected from MW-1 had very high mean concentrations of cadmium $(79 \mu \mathrm{g} / \mathrm{L})$ and zinc $(9,300 \mu \mathrm{g} / \mathrm{L})$. Mean concentrations of arsenic, copper, and lead in well MW-1 were fairly low (Klein, Thamke, and others, 2003). The high 
Table 9. Summary of annual water budget of Frohner Basin.

[+, inflow; -, outflow; >, greater than; <, less than]

\begin{tabular}{lcc}
\hline \multicolumn{1}{c}{ Source } & $\begin{array}{c}\text { Annual inflow } \\
\text { or outflow }\end{array}$ \\
\cline { 2 - 3 } & $\begin{array}{c}\text { Volume } \\
\text { (acre-feet) }\end{array}$ & Percent \\
\hline Precipitation of 25 inches per year on 832 acres & $+1,733$ & +100 \\
Discharge from Frohner Meadows creek; drainage area of 1.30 square miles & -709 & -41 \\
Ground-water flow to Frohner Meadows creek (these values included in stream-discharge & $(>108)$ & $(>6)$ \\
$\quad$ volume and percentage) & -1 & $<1$ \\
Ground-water flow out of basin through till and bedrock & -74 & -4 \\
Potential evapotranspiration from 29.7 acres of wetland & -949 & -55 \\
\hline Evapotranspiration from 802 acres of forest and grass & & \\
\hline
\end{tabular}

concentrations of cadmium and zinc measured for well MW-1 likely are from infiltration of water from Nellie Grant creek (see next section), because the well is near the creek, and concentrations of dissolved cadmium and zinc in the stream are similar to those in ground water at the well. Water samples from the deeper well MW-2 had low concentrations of arsenic, cadmium, copper, lead, and zinc.

\section{Surface Water}

Surface water was sampled at 12 sites (A through J, L-3a, and L-3b) in the Frohner Meadows area (fig. 14). Surfacewater-quality data are reported in Klein, Thamke, and others (2003, table 6). Sample sites A, B, C, and D were located on small tributaries that flow into the wetlands of Frohner Meadows; these tributaries drain areas that show minimal or no disturbance from mining. Sample site F is on Frohner Meadows creek, and site G is on Nellie Grant creek. Sample sites E, $\mathrm{H}, \mathrm{I}$, and $\mathbf{J}$ were selected to show potential changes in quality as water moves downstream through Frohner Meadows and its mill tailings deposits. Sample sites $\mathrm{L}-3 \mathrm{a}$ and $\mathrm{L}-3 \mathrm{~b}$ were located on the two outflows from lower Frohner Meadows.

Specific conductance ranged from $33 \mu \mathrm{S} / \mathrm{cm}$ at tributary inflow site $\mathrm{C}$ to $500 \mu \mathrm{S} / \mathrm{cm}$ at site $\mathrm{G}$ on Nellie Grant creek. In general, specific conductance of all tributary inflows except Nellie Grant creek was less than $100 \mu \mathrm{S} / \mathrm{cm}$, and specific conductance of water discharging from lower Frohner Meadows (sites L-3a and L-3b) ranged from 88 to $483 \mu \mathrm{S} / \mathrm{cm}$. Field measurement of samples indicated mostly neutral $\mathrm{pH}$ values; both the lowest (6.0) and highest (8.2) values were measured in samples collected at site $\mathrm{L}-3 \mathrm{~b}$.

Concentrations of trace metals in tributaries to Frohner Meadows vary greatly by source of inflow (table 3 ). Small tributaries sampled at sites A, B, C, and D typically had low concentrations of arsenic, cadmium, copper, lead, and zinc. Frohner Meadows creek, which drains the area of the Frohner mine, had higher concentrations of trace metals than the small tributaries. The highest concentrations of trace metals were measured in Nellie Grant creek, which drains the adits and reclaimed area of the Nellie Grant mine. High concentrations of trace metals were measured in Frohner Meadows creek in the area between the mill tailings deposits in upper Frohner Meadows and the outlets of lower Frohner Meadows.

Total recoverable arsenic concentrations ranged from less than $2 \mu \mathrm{g} / \mathrm{L}$ in samples from tributaries A and B to $208 \mu \mathrm{g} / \mathrm{L}$ in a sample from Nellie Grant creek. The total recoverable arsenic concentration measured in a sample from Nellie Grant creek exceeds the chronic aquatic-life standard of $150 \mu \mathrm{g} / \mathrm{L}$ (Montana Department of Environmental Quality, 2002). Total recoverable cadmium concentrations ranged from about $0.03 \mu \mathrm{g} / \mathrm{L}$ in samples from tributary sites A and C to $121 \mu \mathrm{g} / \mathrm{L}$ in a sample from Nellie Grant creek. Total recoverable copper concentrations ranged from $2.2 \mu \mathrm{g} / \mathrm{L}$ in a sample from tributary site A to $83.9 \mu \mathrm{g} / \mathrm{L}$ in a sample from Nellie Grant creek. Total recoverable lead concentrations ranged from $<1 \mu \mathrm{g} / \mathrm{L}$ in samples from tributary sites A, B, and C to $72 \mu \mathrm{g} / \mathrm{L}$ in a sample from Nellie Grant creek. Total recoverable zinc concentrations ranged from $2 \mu \mathrm{g} / \mathrm{L}$ in a sample from tributary site $\mathrm{C}$ to $15,100 \mu \mathrm{g} / \mathrm{L}$ in a sample from Nellie Grant creek. At most sites along Frohner Meadows creek and areas downstream from Nellie Grant creek, concentrations of total recoverable cadmium, copper, lead, and zinc exceeded Montana aquatic-life standards (Montana Department of Environmental Quality, 2002).

\section{Trace-Metal Loads}

Instantaneous loads of trace metals into and out of Frohner Meadows were calculated from instantaneous streamdischarge measurements and from measured concentrations of total recoverable trace metals in water samples. Calculated loads are reported in grams per day (table 3). Graphs of instantaneous loads of total recoverable arsenic, cadmium, copper, lead, and zinc are shown in figures 23-27 for two sampling periods. The first set of samples was collected on June 25 and 26, 2001, at all sites A-J and L except L-3. A sample from site $\mathrm{L}-3$ ( $\mathrm{L}-3 \mathrm{a}$ and $\mathrm{L}-3 \mathrm{~b}$ combined) was collected on May 10, 2001, when discharge was slightly greater than it was during the June sampling. The second set of samples was collected on August 1, 2001, at a time of low stream discharge. 


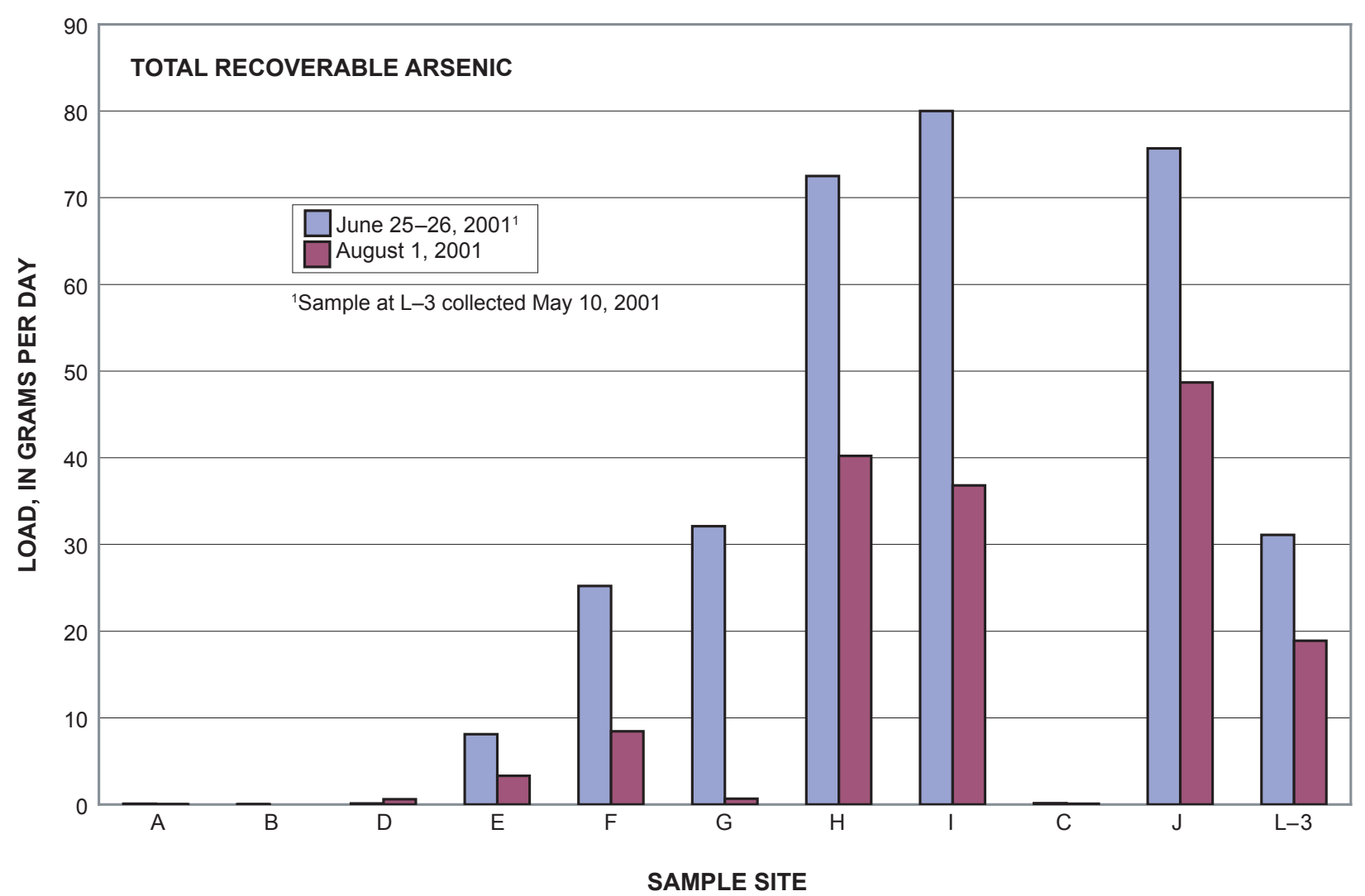

Figure 23. Instantaneous loads of total recoverable arsenic.

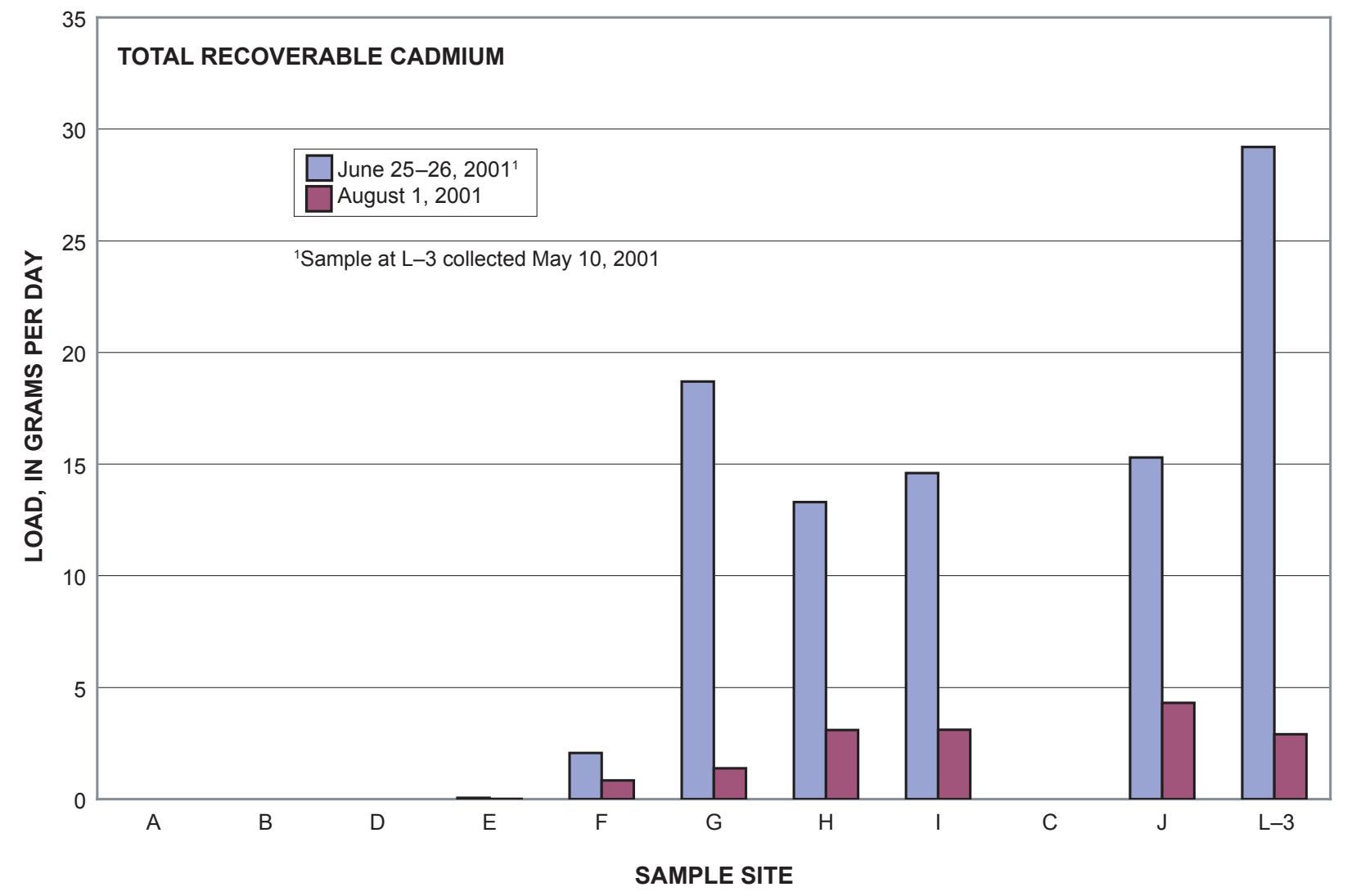

Figure 24. Instantaneous loads of total recoverable cadmium. 


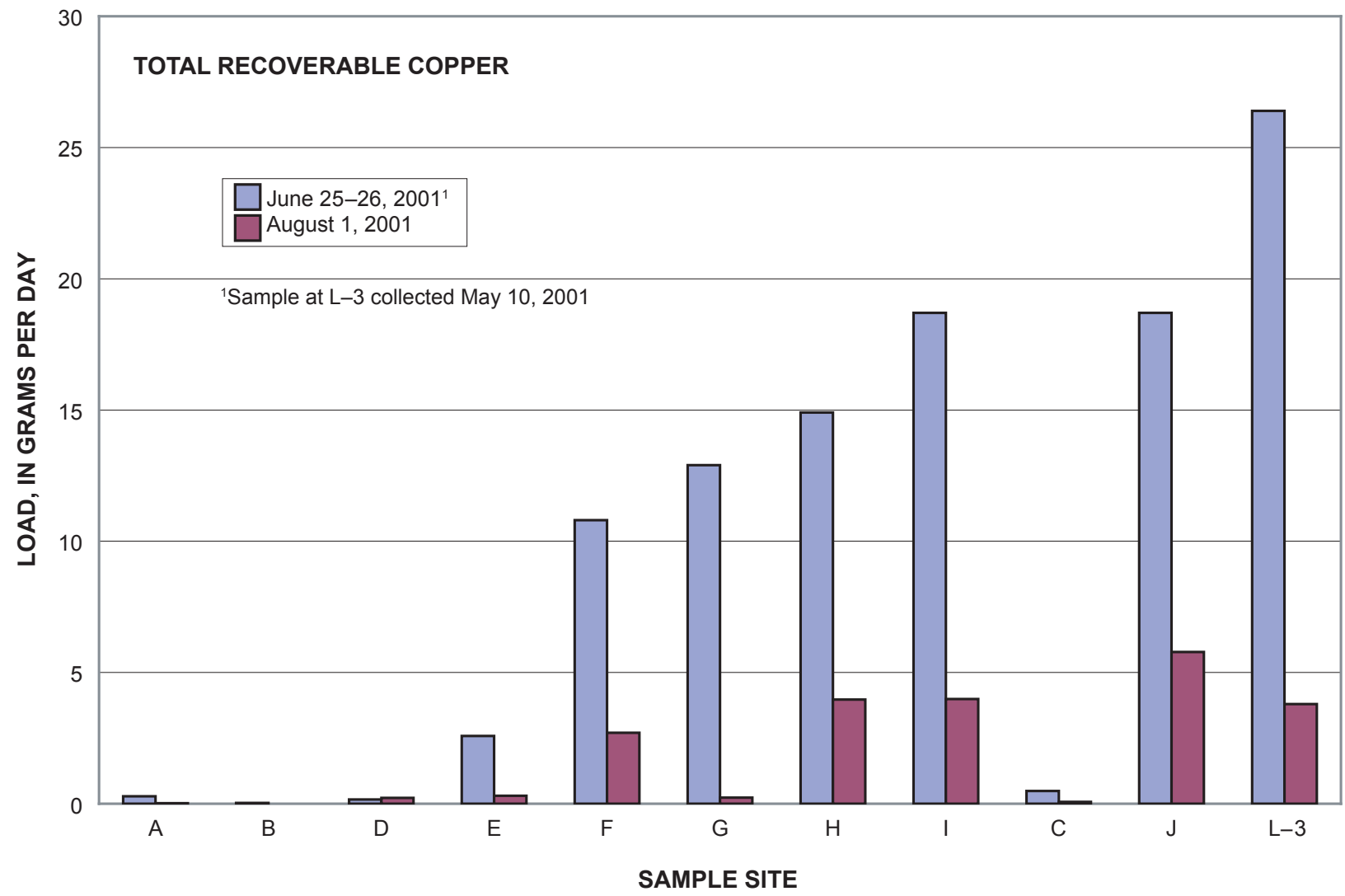

Figure 25. Instantaneous loads of total recoverable copper.

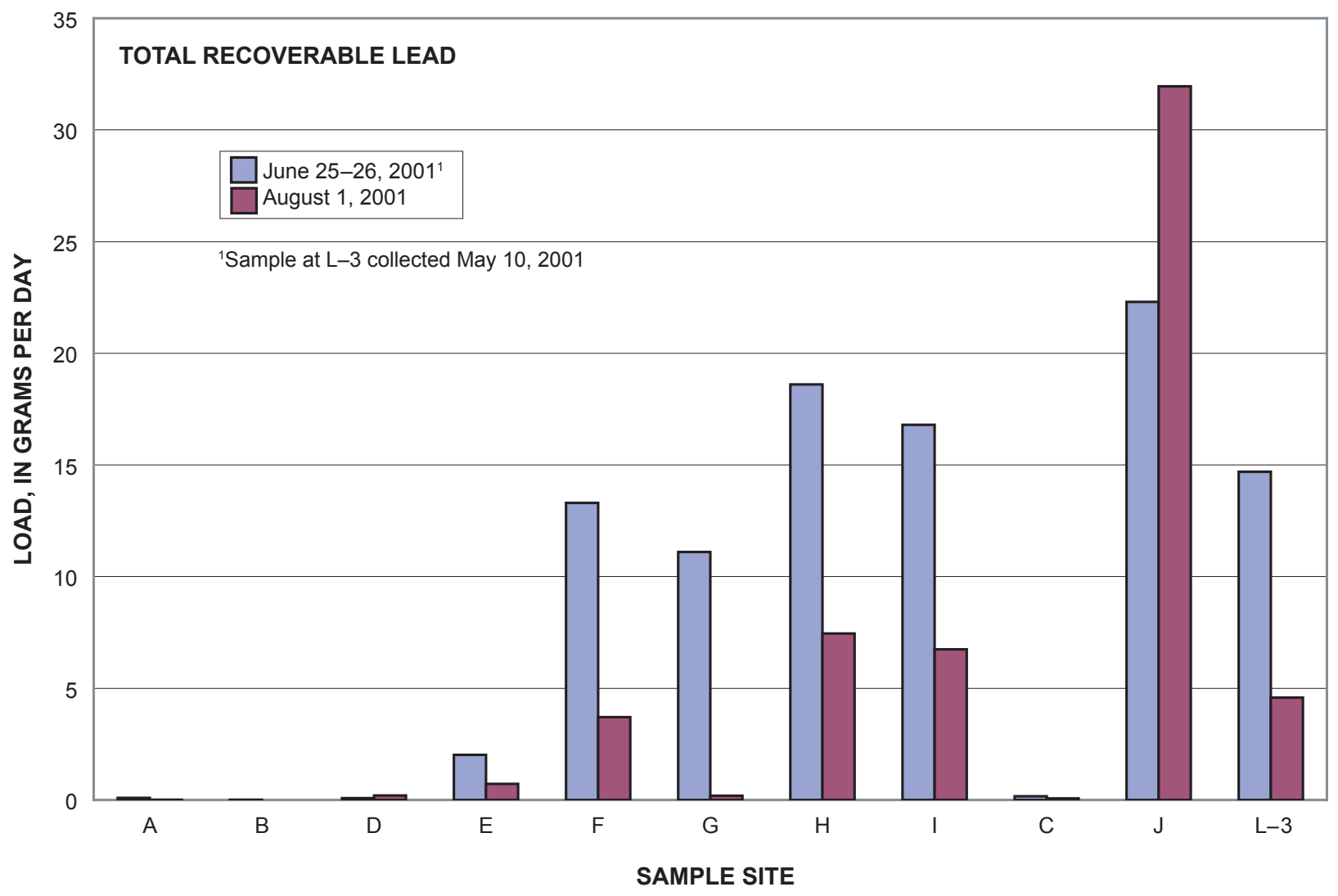

Figure 26. Instantaneous loads of total recoverable lead. 


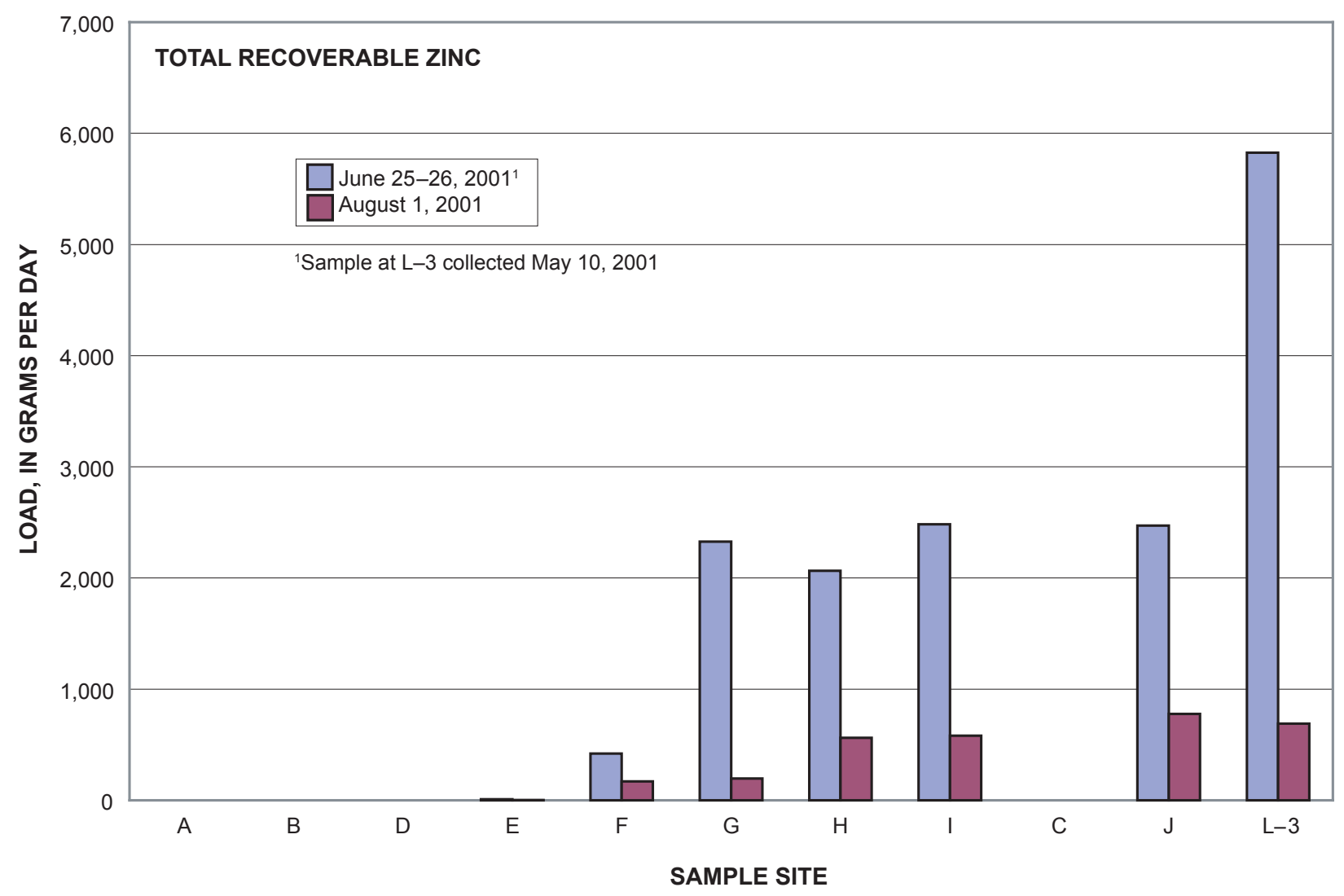

Figure 27. Instantaneous loads of total recoverable zinc.

Small tributaries sampled at sites A, B, C, and D had small loads of trace metals in both the June and August samples. The larger tributaries of Frohner Meadows creek, where it enters upper Frohner Meadows (site F), and Nellie Grant creek (site G) contributed the largest loads of total recoverable arsenic, cadmium, copper, lead, and zinc to upper Frohner Meadows. Sample site E, which discharges from the uppermost beaver pond in upper Frohner Meadows, also contributed small loads of total recoverable arsenic, copper, and lead (figs. 23-27). The largest arsenic loads were measured in Frohner Meadows creek at sites $\mathrm{H}$, I, and J, which are downstream from Nellie Grant creek and the mill tailings deposits in the central part of upper Frohner Meadows. At sites H and I, arsenic loads greater than the sum of arsenic loads in upstream tributaries indicate that additional arsenic is entering Frohner Meadows creek from mill tailings and ground water in that area. A major part of the total recoverable cadmium load in Frohner Meadows creek was contributed by Nellie Grant creek (site G). Cadmium load in Frohner Meadows creek (June 25 or 26 sample) substantially increased downstream from the confluence with Nellie Grant creek and remained high downstream in samples collected at sites $\mathrm{H}, \mathrm{I}$, and $\mathrm{J}$ (fig. 24). Loads of total recoverable copper, lead, and zinc also remained high at downstream sample sites $\mathrm{H}, \mathrm{I}$, and $\mathrm{J}$ (figs. 25-27).

\section{Conclusions}

- The mine and mill sites at the Nellie Grant and Frohner mines contribute significant amounts of ore-related metals to stream bed sediment and surface water in the study area.

- Most surface-water sites in Frohner Meadows below Nellie Grant creek exceed the Montana aquatic-life standards for the ore-related metals cadmium, copper, lead, and zinc (Montana Department of Environmental Quality, 2002).

- A plume of ground water, rich in ore-related metals that likely are derived from infiltration of contaminated surface water at the outlet of Nellie Grant creek, locally transports arsenic, cadmium, and zinc into upper Frohner Meadows.

- Arsenic is transported in shallow ground water in concentrations that exceed the Montana numeric waterquality standard for human health throughout much of Frohner Meadows (Montana Department of Environmental Quality, 2002).

- Much of the metal-enriched sediment in the meadow and wetlands is buried and not identifiable from 
surface features; enriched sediment extends beyond the region of obviously unvegetated areas in upper Frohner Meadows.

- Lower Frohner Meadows effectively traps ore-related metals transported in clastic material.

- Mill tailings in the upper parts of lower Frohner Meadows have a high acid-producing potential and, if oxidized during weathering, could release high concentrations of arsenic, cadmium, and zinc. Removal of this material would reduce the potential for release of high concentrations of arsenic, cadmium, and zinc.

- Estimates of premining background concentrations of metals in buried alluvial and pond-fill deposit in Frohner Meadows are 2.4-4.6 times the watershed background concentrations in active stream sediment in the Prickly Pear Creek watershed. The estimated premining concentration of arsenic (4.1 times as high), lead (4.6 times as high), and zinc (2.4 times as high) indicate that the Frohner Meadows area contains higher natural (premining) concentrations of these metals relative to usual regional concentrations as measured in areas of the Prickly Pear Creek watershed underlain by unmineralized bedrock. The premining background concentrations of arsenic, cadmium, and copper in Frohner Meadows are similar to those of premining sediment in the adjacent upper Boulder River watershed (Church and others, 2004), whereas concentrations of lead and zinc are substantially higher. These high background levels in buried premining material need to be taken into account in any remediation plan.

- It may be possible to excavate and replace contaminated material in upper Frohner Meadows. However, without a reduction in the influx of ore-related metals from upstream sources such as adit water and mine and mill waste, recontamination of Frohner Meadows is likely. The wetlands in lower Frohner Meadows appear to reduce the concentrations of ore-related metals that are transported downstream by clasts in stream bed sediments; the wetlands also, under current conditions, reduce by sorption the concentrations of some watertransported ore-related metals. Disturbance of these wetlands could change downstream surface- and groundwater chemistry and hydrology to produce higher concentrations of arsenic, cadmium, and zinc in surface water in upper Lump Gulch; disturbance might also reduce the ability of the wetland to trap clastic particles.

\section{Summary}

\section{Mine Waste and Mill Tailings}

Frohner mine and mill tailings typically contain the highest concentrations of arsenic and lead in the study area, as shown by total-metal concentrations in bulk samples and core material downstream from the Frohner mill. Results of the EPA-1312 leach procedure (Klein, Thamke, and others, 2003) showed that the high summed concentrations of ore-related metals are dominated by lead. Analyses of two size fractions in mill tailings from area A showed that coarse quartz chips (>2 mm), which probably are unprocessed ore, also contained high concentrations of lead and relatively low concentrations of zinc; the coarse fraction also had a higher acid-generating capacity than the finer fraction, probably owing to unweathered pyrite in the quartz chips that was not removed during ore processing. Fine-grained material $(<2 \mathrm{~mm})$ from area A had a low acid-generating capacity (table 1) and lower summed-metal concentrations. Bulk mine waste and mill tailings from the Nellie Grant mine and mill contained high concentrations of cadmium and zinc relative to similar material from the Frohner mine and mill, as seen in bulk analyses of the debris fan below Nellie Grant creek. Acid-generating capacity is low for all surface samples of mill tailings in area B (fig. 3) and for material of mixed sources from the Nellie Grant and Frohner mines.

The acid-generating capacity of material from the milltailings delta in lower Frohner meadows is extremely high (table 1) relative to other waste material in the study area and elsewhere. Oxidation of this material, which might occur if water levels were lowered, would generate acidic, metal-rich water. The fine grain size of this unencapsulated material makes it more susceptible to weathering. This material is likely to contribute metals as dissolved or suspended constituents in surface water and ground water or as adsorbed material or colloids in stream bed sediment in lower Frohner Meadows and upper Lump Gulch. On the basis of the EPA-1312 leach data from surface samples, these mill tailings have large concentrations of readily leachable arsenic, cadmium, and zinc and probably contribute to the solution-transported load of metals in surface water in lower Frohner Meadows. The effects of acid generated by oxidation of this material could be mitigated by the neutral and mildly alkaline nature of the surface water in the study area (see table 4, Klein, Thamke, and others, 2003) and the probable high acid-neutralizing capacity of the local bedrock. The granitic rocks of the Boulder batholith that underlie the study area have a high capacity for neutralizing acid that results in characteristically neutral to mildly alkaline $\mathrm{pH}$ in surface water and the rapid neutralization of acid produced by anthropogenic and natural sources (Desborough and others, 1998).

\section{Area A-Upper Frohner Meadows}

In area A (fig. 3), mine waste is present in the debris fan at the edge of upper Frohner Meadows and in material that has been deposited below the fan in the meadow proper near the east end of core line 1 and near core line 2. In most cases, mine waste, characterized by coarse quartz lag deposits that probably are untreated ore from the Frohner mill, is mixed with fine-grained mill tailings. These mixed deposits overlie fine-grained mill tailings that were discharged into 
or accumulated within premining ponds. The coarse mine waste probably was transported downstream during flood events after a structural failure at the abandoned Frohner mill. Fine-grained mill tailings enriched in ore-related metals were redistributed by stream action along Frohner Meadows creek between the debris fan and the area of core line 2. Each of the eight cores analyzed in this area was enriched in ore-related metals relative to local background concentrations.

Weathering in the upper part of the debris fan has leached arsenic, cadmium, and zinc from the surface and enriched the underlying nontailings material in those metals. This downward migration of metal substantially increased the thickness of the enriched intervals. The mean minimum thickness of the enriched intervals (mill tailings and underlying contaminated material) in this area is $52 \mathrm{~cm}$. The weighted average concentration of these metals in enriched intervals was 3,500 ppm for arsenic, $12 \mathrm{ppm}$ for cadmium, $270 \mathrm{ppm}$ for copper, 3,500 ppm for lead, and 1,200 ppm for zinc. The concentrations of arsenic and lead are relatively high compared with their concentrations in other enriched material in the study area; all concentrations exceed the consensus-based probable-effect concentration (CBPEC) for stream bed sediment (table 6). Mine waste in the debris fan contributes little clastic material to stream bed sediment downstream during low flow because the creek is not actively eroding the debris fan. Mill tailings deposited in the meadow are effectively stabilized by heavy vegetation and contribute only a small amount of clastic material to the stream bed sediment under low-flow conditions.

\section{Area B-Upper Frohner Meadows}

Deposits of coarse-grained crushed (but unprocessed) ore, probably from the Frohner mill, mix downstream with fine-grained mill tailings and fluvial mill tailings from the Frohner and Nellie Grant mines. This material is impounded behind a large reinforced beaver dam. Typically, quartz-rich, fluvial mill tailings mixed with fluvially transported, crushedore material overlie thinly bedded fine-grained mill tailings that were deposited in shallow ponds. The calculated mean minimum thickness of enriched material in this area is 79 $\mathrm{cm}$. However, the mean thickness is likely to be somewhat greater, because the bottom of the enriched material was not reached in cores from the mill tailings fan on the west side of upper Frohner Meadows (fig. 13). The enriched material contained weighted-average metal concentrations of 2,000 ppm for arsenic, $36 \mathrm{ppm}$ for cadmium, $290 \mathrm{ppm}$ for copper, $2,700 \mathrm{ppm}$ for lead, and 2,900 ppm for zinc. The material was highly enriched in cadmium and zinc relative to weightedaverage concentrations of material from area A upstream from this area. However, this enriched material far exceeds CBPEC concentrations for stream bed sediment (table 6) for all five ore-related metals. Samples from core line 4 (fig. 3) below the impoundment dam contained a moderate thickness of enriched material in one of two sites. The core at site $4-0$ is was slightly enriched in arsenic; the arsenic may have been transported by ground water from the main mill-tailings impoundment. It was substantially enriched in cadmium and zinc relative to samples from core line 3 (fig. 3); surface water from upstream sources probably transported these metals in solution.

\section{Area C-Lower Frohner Meadows}

The main source of enriched material in lower Frohner Meadows is the mill tailings delta in the water-filled pond at the west end of the meadow (fig. 16). This delta contains mill tailings from the latest production episode at the Nellie Grant mine, which ended in the early 1980s. One core (LFMC 1) from the southern end of the delta contained $96 \mathrm{~cm}$ of contaminated material where it is above water. The thickness of contaminated material may increase where the delta is submerged in the pond. The thickness-weighted mean concentrations of 2,300 ppm for arsenic, $50 \mathrm{ppm}$ for cadmium, $240 \mathrm{ppm}$ for copper, 1,800 ppm for lead, and 5,200 ppm for zinc were about half of the concentrations of those metals found in the bulk surface sample from the exposed part of the delta (LFM 1, fig. 15 of this report; Klein, Thamke, and others, 2003), and this difference suggests that these deposits may be stratified. The extent of the mill tailings is not well documented, and the horizontal extent and thickness of contaminated material in the pond were not established.

Core samples from core lines 5 and 6 , downstream from the mill-tailings delta, contained weighted-average concentrations of $280 \mathrm{ppm}$ for arsenic, $11 \mathrm{ppm}$ for cadmium, 190 ppm for copper, $600 \mathrm{ppm}$ for lead, and $850 \mathrm{ppm}$ for zinc. Enrichment of material in area $\mathrm{C}$ is thus relatively minor compared with the material upstream in areas $\mathrm{A}$ and $\mathrm{B}$, but concentrations of all metals exceeded the CBPEC for stream bed sediment (table 6). Sampling was not sufficient to determine a mean thickness of the enriched unit, but all samples of enriched material came from shallow, buried, fine-grained pond-fill deposits or present-day meadow soils. A breached beaver pond transected by core line 6 contains high concentrations of arsenic, cadmium, lead, and zinc; these metals are in a thin surficial layer of fine-grained, organic-rich pond bottom material that is eroding into the active channel during periods of high water (fig. 15). Downstream plots of stream bed sediment (figs. 17, 18, 20, 21, and 22) suggest that metal was added to the stream from the mill-tailings delta at the head of the lower meadow.

The wetlands near the outlet of lower Frohner Meadows (above site L-3b and L-158, fig. 3) provide a barrier to clasticsediment transport and may be accumulating cadmium and zinc from ground and surface water in manganese-oxyhydroxide grain coatings of stream bed sediment and buried sediment.

\section{Upper Lump Gulch}

Cores from the sediment-filled reservoir in upper Lump Gulch (fig. 3) were enriched, in a minor and erratic manner, in arsenic, cadmium, lead, and zinc. Small arsenic, cadmium, and zinc accumulations are associated with sediments that are enriched in manganese. This association suggests that 
arsenic, cadmium, and zinc-which originated in ground and surface water flowing from Frohner Meadows into upper Lump Gulch - are being deposited in manganese oxyhydroxides. Lead, which enriched the deepest part of core LGFR 3 , probably is present in clastic material that was deposited early in the sedimentation history of this site and may have existed naturally in the premining environment. Stream bed sediment at the northwest side of this reservoir (site L-158) contains very high concentrations of arsenic, cadmium, lead, and zinc, similar to concentrations of those metals at site L-3b immediately upstream. Cleanup of the present-day channel-fill material in the sediment-filled reservoir may prevent further movement of some easily transported metal-enriched clastic material into upper Lump Gulch. However, removal of the deep fill material underlying the reservoir site might not be necessary or desirable, because the deep material may be absorbing some arsenic, cadmium, and zinc from ground and surface water flowing from lower Frohner Meadows into upper Lump Gulch.

\section{Panama Mine Meadows}

An unused reservoir in Panama mine meadows (fig. 3) is filled with medium- to coarse-grained granitic debris from the surrounding bedrock. Samples of fine-grained pond-bottom sediment in one core were locally slightly enriched in lead and arsenic; the source of the excess lead and arsenic is not clear. Two possible sources of lead and arsenic are material transported from several small mines located on the drainage divide above the reservoir about $1 \mathrm{mi}$ west of the reservoir (Becraft and others, 1963) and material derived from unexploited deposits in a poorly exposed vein system above the reservoir. Downstream from this reservoir, stream bed sediment was not significantly enriched in ore-related metals.

\section{Stream Bed Sediment}

Chemical analyses indicate that stream bed sediment in the study area downstream from the mine waste and mill tailings area is substantially enriched in ore-related metals relative to background concentrations in the watershed (table 5). As compared with the median background concentrations in upper Prickly Pear Creek watershed, arsenic typically is 5-250 times as high, cadmium is 3-75 times as high, copper is 1.5-10 times as high, lead is 2.5-300 times as high, and zinc is 4-75 times as high in 15 of 18 sample sites in the meadow area. Concentrations at most sites also exceed the CBPEC stream bed-sediment screening concentrations of MacDonald and others (2000) for arsenic, cadmium, lead, and zinc.

The highest concentrations of lead are below the Frohner mill in Frohner Meadows creek. Decreasing concentrations toward the meadow outlet (site L-3b, fig. 3) indicate that lead minerals are transported as clastic grains and are diluted by less-enriched material. The main mill-tailings pond (area B, fig. 3) and the Nellie Grant mill-tailings fan in the lower meadow (area C) are minor sources of lead in sediments downstream from those sites. Material in the main Frohner mill-tailings pond enriches stream bed sediment below the pond in arsenic, cadmium, lead, and zinc to a greater degree than was measured in sediment below the upper mill tailings (area A). The highest concentrations of arsenic, cadmium, and zinc in sediment are at the meadow outlet (site $\mathrm{L}-3 \mathrm{~b}$ ). This apparent lack of dilution through the meadow system suggests that these metals were transported in dissolved or suspended form in surface water and were redeposited, perhaps by adsorption on iron and manganese oxyhydroxide grain coatings or in colloidal material, near the meadow outlet.

Site L-158, immediately below the outlet of Frohner Basin and upstream from the sediment-filled reservoir in upper Lump Gulch (fig. 3), is highly enriched relative to background concentrations in the watershed of all ore-related metals except copper. Concentrations at this site are similar to those at L-3b, located at the outlet to Frohner Basin and immediately upstream from L-158, for all metals except lead; lead is markedly higher. These high lead concentrations at the break in gradient at the edge of the sediment-filled reservoir may have resulted from the local accumulation of metal-rich clastic material during a large flood. Substantial decreases in concentrations of all ore-related metals are apparent between sites L-158 and L-156 immediately downstream from the outlet of the sediment-filled reservoir. These decreases probably are due to dilution by water and sediment from an unnamed tributary that enters the filled reservoir from the south.

\section{Hydrology}

Ground water discharged from unconsolidated deposits plays an important role in maintaining the wetland environment of Frohner Meadows. Ground water, moving from topographically higher areas within Frohner Basin, flows predominantly through thin unconsolidated deposits at the uppermost weathered zone on top of bedrock and discharges to land surface in the wetland areas of Frohner Meadows. Ground water discharged in the wetland areas slightly increases stream discharge, especially in the downstream part of upper Frohner Meadows. Little ground water is discharged through moraine and bedrock downstream from lower Frohner Meadows.

Frohner Basin surface water is drained entirely through Frohner Meadows creek, which drains into Lump Gulch and eventually into Prickly Pear Creek. Frohner Meadows creek flows adjacent to the Frohner mine and enters the wetlands in the northwestern part of upper Frohner Meadows. An unnamed tributary, referred to as "Nellie Grant creek" in this report, originates at the Nellie Grant mine and enters the wetlands in the west-central part of upper Frohner Meadows. Calculated mean annual stream discharge of Frohner Meadows creek at the outlet of lower Frohner Meadows is $0.98 \mathrm{ft}^{3} / \mathrm{s}$. Calculated mean monthly stream discharge ranges from $0.19 \mathrm{ft}^{3} / \mathrm{s}$ in January to $3.8 \mathrm{ft}^{3} / \mathrm{s}$ in May. 
An annual water budget for Frohner Basin was developed to evaluate relative volumes of water that are lost through surface water and ground water discharge and through evapotranspiration. Average annual precipitation, about 25 in., produces about 1,733 acre- $\mathrm{ft}$ of recharge to the $1.30 \mathrm{mi}^{2}$ drainage basin. That volume of water leaves the basin as evapotranspiration from forest and grass (55 percent of total), stream discharge (41 percent of total), evapotranspiration from wetlands (4 percent of total), and groundwater discharge through till and bedrock (less than 1 percent of total).

\section{Ground-Water Quality}

Dissolved arsenic was present in most (10 of 14) groundwater samples in concentrations exceeding the Montana numeric water-quality standard for human health of $20 \mu \mathrm{g} / \mathrm{L}$ in ground water (Montana Department of Environmental Quality, 2002). The highest concentration $(3,380 \mu \mathrm{g} / \mathrm{L})$ was measured in a sample collected on October 17, 2001, from well FM-1; this well is completed in an area of mill tailings in upper Frohner Meadows (fig. 14). Water from well FM-4, which is completed in an area of fluvial mill tailings derived from the Frohner mine, also had a high concentration of arsenic $(414 \mu \mathrm{g} / \mathrm{L})$. Concentrations of dissolved cadmium, copper, and lead were low in samples from all wells completed for this study and were below the maximum limits of human-health standards for drinking water (Montana Department of Environmental Quality, 2002). Dissolved zinc concentrations ranged from less than $1 \mu \mathrm{g} / \mathrm{L}$ in a sample from well FM-3 to $419 \mu \mathrm{g} / \mathrm{L}$ in a sample from well FM-9. High concentrations of cadmium and zinc measured in ground water in well MW-1, which was completed in a previous study, suggest that these metals may be transported locally by infiltration of contaminated surface water from Nellie Grant creek into upper Frohner Meadows.

\section{Surface-Water Quality}

Concentrations of ore-related trace metals in tributaries to Frohner Meadows vary greatly by source of inflow. Small, undisturbed tributaries typically have low concentrations of arsenic, cadmium, copper, lead, and zinc. Frohner Meadows creek, which drains the area that includes the Frohner mine, has higher concentrations of trace metals than the small tributaries that are undisturbed by mining. The highest concentrations of all ore-related trace metals were measured in Nellie Grant creek, which drains the underground workings and reclaimed area of the Nellie Grant mine.

Instantaneous loads of trace metals into and out of Frohner Meadows were calculated from instantaneous streamdischarge concentrations and measured concentrations of total recoverable trace metals in water samples. Small tributaries sampled at sites A, B, C, and D (fig. 14) had small loads of trace metals in both the June and August sample sets. The larger tributaries of Frohner Meadows creek, where they enter upper Frohner Meadows (site F), and Nellie Grant creek (site
G) contributed the largest loads of total recoverable arsenic, cadmium, copper, lead, and zinc to upper Frohner Meadows. The largest arsenic loads in surface water were measured in Frohner Meadows creek at sites H, I, and J, which are downstream from Nellie Grant creek, and in the main mill-tailings deposits in the central part of upper Frohner Meadows. The large arsenic loads at these sites indicate that additional arsenic is entering Frohner Meadows creek from mill tailings and ground water in that area. A major part of the cadmium load in Frohner Meadows creek is contributed by Nellie Grant creek, which drains the area of the Nellie Grant mine.

\section{References Cited}

Bacon, C.R., 1983, Eruptive history of Mount Mazama and Crater Lake caldera, Cascade Range, U.S.A.: Journal of Volcanology and Geothermal Research, v. 18, p. 57-115.

Becraft, G.E., Pinckney, D.M., and Rosenblum, Sam, 1963, Geology and mineral deposits of the Jefferson City quadrangle, Jefferson and Lewis and Clark Counties, Montana: U.S. Geological Survey Professional Paper 428, 101 p.

Bouwer, Herman, 1978, Groundwater hydrology: New York, McGraw-Hill Book Company, 480 p.

Bowen, H.J.M., 1979, Environmental chemistry of the elements: New York, Academic Press, 333 p.

Briggs, P.H., 1996, Forty elements by inductively coupled plasma-emission spectroscopy, in Arbogast, B.F., ed., Analytical methods manual for the Mineral Resources Program: U.S. Geological Survey Open-File Report 96-525, p. 77-94.

Church, S.E., Holmes, C.E., Briggs, P.H., Vaughn, R.B., Cathcart, Jim, and Marot, M., 1993, Geochemical and leadisotope data from stream and lake sediment, and cores from the upper Arkansas River drainage-Effects of mining at Leadville, Colorado, on heavy-metal concentrations in the Arkansas River: U.S. Geological Survey Open-File Report 93-534, $61 \mathrm{p}$.

Church, S.E., Unruh, D.M., Fey, D.L., and Sole, T.C., 2004, Trace elements and lead isotopes in streambed sediment in streams affected by historical mining, chap. D8 of Nimick, D.A., Church S.E., and Finger, S.E., eds., Integrated investigations of environmental effects of historical mining in the Basin and Boulder mining districts, Boulder River watershed, Jefferson County, Montana: U.S. Geological Survey Professional Paper 1652, p. 279-335.

Desborough, G.A., Briggs, P.H., and Mazza, N., 1998, Chemical and mineralogical characteristics and acid-neutralizing potential of fresh and altered rocks and soils of the Boulder River headwaters in Basin and Cataract Creeks of northern Jefferson County, Montana: U.S. Geological Survey OpenFile Report 98-40, 21 p. 
Faires, L.M., 1993, Methods of analysis by the U.S. Geological Survey National Water Quality LaboratoryDetermination of metals in water by inductively coupled plasma-mass spectrometry: U.S. Geological Survey OpenFile Report 92-634, 28 p.

Farag, A.M., Nimick, D.A., Kimball, B.A., Church, S.E., Skaar, Don, Brumbaugh, W.G., McConnel, Elizabeth, and Hogstrand, Christer, 2004, Aquatic health and exposure pathways of trace elements, chap. D10 of Nimick, D.A., Church, S.E., and Finger, S.E., eds., Integrated investigations of environmental effects of historical mining in the Basin and Boulder mining districts, Boulder River watershed, Jefferson County, Montana: U.S. Geological Survey Professional Paper 1652, p. 369-400.

Fey, D.L., Desborough, G.A., and Church, S.E., 2000, Comparison of two leach procedures applied to metal-mining wastes in Colorado and Montana and a relative ranking method for mine wastes, in International Conference on Acid Rock Drainage, 5th, Denver, Colo., 2000, Proceedings: Lakewood, Colo., Society for Mining, Metallurgy and Exploration, Inc., p. 1477-1487.

Fey, D.L., Desborough, G.A., and Finney, C.J., 2000, Analytical results for total digestions, EPA-1312 leach, and net-acid production for twenty-three abandoned metal-mining related wastes in the Boulder River watershed, northern Jefferson County, Montana: U.S. Geological Survey Open-File Report 00-0114, 19 p.

Fey, D.L., Nash, J.T., Yager, D.B., and Desborough, G.A., 2000, Analytical results for mine dump samples and leachate solutions, upper Animas River watershed, San Juan County, Colorado: U.S. Geological Survey Open-File Report 00-0338, 19 p.

Fishman, M.J., 1993, Methods of analysis by the U.S. Geological Survey National Water Quality LaboratoryDetermination of inorganic and organic constituents in water and fluvial sediment: U.S. Geological Survey OpenFile Report 93-125, 217 p.

Fishman, M.J., and Friedman, L.C., 1989, Methods for determination of inorganic substances in water and fluvial sediment: U.S. Geological Survey Techniques of Water Resources Investigations, book 5, chapter A1, 709 p.

Garbarino, J.R., 1999, Methods of analysis by the U.S. Geological Survey National Water Quality LaboratoryDetermination of dissolved arsenic, boron, lithium, selenium, strontium, thallium, and vanadium using inductively coupled plasma-mass spectrometry: U.S. Geological Survey Open-File Report 99-093, 31 p.

Garbarino, J.R., and Struzeski, T.M., 1998, Methods of analysis by the U.S. Geological Survey National Water Quality Laboratory-Determination of elements in whole-water digests using inductively coupled plasma-optical emission spectrometry and inductively coupled plasma-mass spectrometry: U.S. Geological Survey Open-File Report 98-165, $101 \mathrm{p}$.

Hoffman, G.L., Fishman, M.J., and Garbarino, J.R., 1996, Methods of analysis by the U.S. Geological Survey National Water Quality Laboratory-In-bottle acid digestion of whole-water samples: U.S. Geological Survey Open-File Report 96-225, 28 p.

Horowitz, A.J., 1991, A primer on sediment trace element geochemistry ( $2 \mathrm{~d}$ ed.): Chelsea, Mich., Lewis Publishers, Inc., $136 \mathrm{p}$.

Ispolatov, V.O., 1997, ${ }^{40} \mathrm{Ar} /{ }^{39} \mathrm{Ar}$ geochronology of the Lowland Creek volcanic field and its temporal relations with other Eocene volcanic areas: Norfolk, Va., Old Dominion University, M.S. thesis, $95 \mathrm{p}$.

Jones, S.R., and Garbarino, J.R., 1999, Methods of analysis by the U.S. Geological Survey National Water Quality Laboratory-Determination of arsenic and selenium in water and sediment by graphite furnace-atomic absorption spectrometry: U.S. Geological Survey Open-File Report 98-639, 39 p.

Klein, T.L., Cannon, M.R., and Fey, D.L., 2003, Hydrogeologic, water quality, and geochemical data for the Frohner Meadows area, upper Lump Gulch, Jefferson County, Montana: U.S. Geological Survey Open-File Report 03-248, 56 p.

Klein, T.L., Thamke, J.N., and Farag, A.M., 2001, Waterquality, biology, and streambed-sediment data and preliminary geochemical interpretations for streams in the upper Prickly Pear Creek watershed, Montana, 2000: U.S. Geological Survey Open-File Report 01-280, 58 p.

Klein, T.L., Thamke, J.N., Harper, D.D., Farag, A.M., Nimick, D.A., and Fey, D.L., 2003, Water-quality, bed-sediment, and biological data for streams in the upper Prickly Pear Creek watershed, Montana, 2001: U.S. Geological Survey OpenFile Report 03-032, 102 p.

Lapakko, K.A., and Lawrence, L.W., 1993, Modification of the net acid production (NAP) test, in British Columbia Mine Reclamation Symposium, 17th, Port Hardy, British Columbia, 1993, Proceedings: p. 145-159.

Lohman, S.W., 1972, Ground-water hydraulics: U.S. Geological Survey Professional Paper 708, 70 p.

MacDonald, D.D., Ingersol, C.G., and Berger, T.A., 2000, Development and evaluation of consensus-based sediment quality guidelines for freshwater ecosystems: Archives of Contamination and Toxicology, v. 39, p. 20-31.

Maxim Technologies, 1999, Final engineering evaluation of potential repository sites, Bearverhead-Deerlodge and Helena National Forests, Lewis and Clark, Powell, and Jefferson Counties, Montana: Helena, Mont., prepared for 
USDA Forest Service, Region 1, Missoula, Mont., variously paged.

McDougal, R.R., Cannon, M.R., Smith, B.D., and Ruppert D.A., 2004, Hydrology of the Boulder River watershed study area, and examination of regional ground-water flow using interpreted fracture mapping from remote sensing data, chap. D9 of Nimick, D.A., Church, S.E., and Finger, S.E., eds., Integrated investigations of environmental effects of historical mining in the Basin and Boulder mining districts, Boulder River watershed, Jefferson County, Montana: U.S. Geological Survey Professional Paper 1652, p. 334-368.

Metesh, John, Lonn, Jeff, Marvin, Rich, Hargrave, Phyllis, and Madison, James, 1998, Abandoned-inactive mines, Helena National Forest, v. I-Upper Missouri River drainage: Montana Bureau of Mines and Geology Open-File Report 352, variously paged.

Montana Department of Environmental Quality, 2002, Montana numeric water-quality standards: Helena, Montana, Planning, Prevention, and Assistance Division-Water Quality Standards Section Circular WQB-7, 37 p.

National Oceanic and Atmospheric Administration, 1982, Evaporation atlas for the contiguous 48 United States: NOAA Technical Report NWS 33, 26 p.

Nimick, D.A., and Cleasby, T.E., 2000, Water-quality data for streams in the Boulder River watershed, Jefferson County, Montana: U.S. Geological Survey Open-File Report 00-99, 70 p.

Parrett, Charles, and Johnson, D.R., 1989, Estimates of monthly streamflow characteristics at selected sites in the upper Missouri River Basin, Montana, base period water years 1937-86: U.S. Geological Survey Water-Resources Investigations Report 89-4082, 103 p.
Pioneer Technical Services, 1996, Expanded engineering evaluation/cost analysis for the Nellie Grant mine: Butte, Mont., Pioneer Technical Services, Inc., variously paged.

Pioneer Technical Services, 2000, Final expanded engineering evaluation/cost analysis for the Frohner mine site: Butte, Mont., Pioneer Technical Services, Inc., variously paged.

Price, W.A., Morin, K., and Hutt, N., 1997, Guidelines for the prediction of acid rock drainage and metal leaching for mines in British Columbia, pt. II. Recommended procedures for static and kinetic testing, in International Conference on Acid Rock Drainage, 4th, Vancouver, B.C., 1997, Proceedings: p. 15-30.

Roby, R.N., Ackerman, W.C., Fulkerson, F.B., and Crowley F.A., 1960, Mines and mineral deposits (except fuels), Jefferson County, Montana: Montana Bureau of Mines and Geology Bulletin 16, 122 p.

Rose, A.W., Hawkes, H.E., and Webb, J.S., 1979, Geochemistry in mineral exploration ( $2 \mathrm{~d}$ ed.): New York, Academic Press, $657 \mathrm{p}$.

U.S. Environmental Protection Agency, 1986. Test methods for evaluating solid waste, v. I and II (SW-846) (3d ed.), November: Updates are available through Revision 2B, published April 4, 1995.

U.S. Soil Conservation Service, 1977, Average annual precipitation in Montana, based on 1941-70 data: Bozeman, Montana, $13 \mathrm{p}$.

Wilde, F.D., Radtke, D.B., Gibs, Jacob, and Iwatsubo, R.T., 1998, National field manual for the collection of waterquality data: U.S. Geological Survey Techniques of WaterResources Investigations, book 9, p. A1-A9.

Published in the Central Region, Denver, Colorado

Manuscript approved for publication November 28, 2005

Graphics by author

Photocomposition by Mari L. Kauffmann (Contractor, ATA Services)

Edited by Mary-Margaret Coates (Contractor, ATA Services) 